REMEDIAÇÃO DE UM ARGISSOLO VERMELHO AMARELO DISTRÓFICO IRRIGADO COM EFLUENTE INDUSTRIAL CITRÍCOLA COM O CULTIVO DO CAPIM-DE-RHODES (Chloris gayana, Kunth)

MARCOS DE FERRAN

Dissertação apresentada à Escola Superior de Agricultura “Luiz de Queiroz”, Universidade de São Paulo, para obtenção do título de Mestre em Agronomia, Área de Concentração: Solos e Nutrição de Plantas.

P I R A C I C A B A

Estado de São Paulo - Brasil

Fevereiro - 2004 
REMEDIAÇÃO DE UM ARGISSOLO VERMELHO AMARELO DISTRÓFICO IRRIGADO COM EFLUENTE INDUSTRIAL CITRÍCOLA COM O CULTIVO DO CAPIM-DE-RHODES (Chloris gayana, Kunth)

\section{MARCOS DE FERRAN \\ Engenheiro Agrônomo}

Orientador: Prof. Dr. JAIRO ANTONIO MAZZA

Dissertação apresentada à Escola Superior de Agricultura “Luiz de Queiroz”, Universidade de São Paulo, para obtenção do título de Mestre em Agronomia, Área de Concentração: Solos e Nutrição de Plantas.

P I R A C I C A B A

Estado de São Paulo - Brasil

Fevereiro - 2004 
Dados Internacionais de Catalogação na Publicação (CIP) DIVISÃO DE BIBLIOTECA E DOCUMENTAÇÃO - ESALQ/USP

\section{De Ferran, Marcos}

Remediação de um argissolo vermelho amarelo distrófico irrigado com efluente industrial citrícola com o cultivo do Capim-de-rhodes (Chloris gayana, Kunth) / Marcos De Ferran. - - Piracicaba, 2004.

65 p. : il.

Dissertação (mestrado) - - Escola Superior de Agricultura Luiz de Queiroz, 2004. Bibliografia.

1. Capim-de-rhodes 2. Efluente 3. Fertilizante nitrogenado 4. Fertilizante potássico ! Irrigação 6. Manejo do solo 7. Química do solo 8. Solo argiloso I. Título

CDD 631.411

"Permitida a cópia total ou parcial deste documento, desde que citada a fonte - O autor" 
À minha família, meu maior bem, Daniela, Pauline e Camille,

DEDICO

Aos meus queridos Pais Luc e Maria Lúcia

e irmãos Márcia e Gil

OFEREÇO 


\section{AGRADECIMENTOS}

Ao amigo e orientador Prof. Dr. Jairo Antonio Mazza, pelo apoio durante todas as fases do trabalho.

Ao amigo Prof. Dr. Rafael Roberto Aloisi, pela oportunidade gerada em realizar o trabalho na Fazenda Trindade, envolvendo tema tão importante nos dias de hoje.

A todos os colaboradores do Grupo Fischer / Citrosuco e da Fazenda Trindade envolvidos neste trabalho, sem os quais não seria possível a sua realização.

Aos estagiários Arthur, Marcos e Gustavo pela sua boa vontade em colaborar nos trabalhos de campo e laboratório.

Aos amigos da Pós-Graduação, pela disposição em ajudar sempre que possível.

Aos funcionários do Departamento de Solos e Nutrição de Plantas, especialmente os Srs. Dorival Grisotto e Jair Ferrer, pelo empenho durante as viagens ao campo.

À Nancy de Campos Amaral, secretária da Pós-Graduação, pela paciência e cordialidade ao longo dos dois anos do mestrado.

Ao amigo Luís Rosenfeld, pela oportunidade profissional oferecida e pela cessão do tempo requerido à realização deste trabalho.

À Daniela, minha esposa, pela preocupação e apoio em todas as fases do trabalho. 


\section{SUMÁRIO}

Página

LISTA DE FIGURAS …............................................................................. vii

LISTA DE TABELAS ....................................................................................

LISTA DE ABREVIATURAS E SÍMBOLOS .................................................. xii

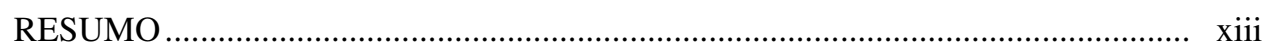

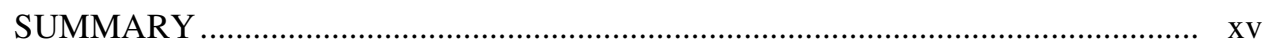

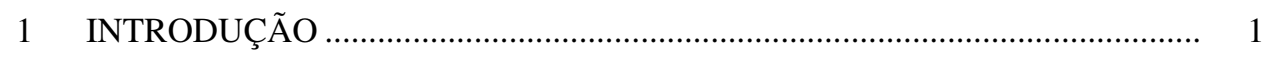

2 REVISÃO DE LITERATURA …............................................................. 3

2.1 Comportamento e efeitos do sódio no solo ................................................. 3

2.2 Parâmetros de avaliação dos efeitos do $\mathrm{Na}$.............................................. 5

2.2.1 Águas de irrigação..................................................................... 5

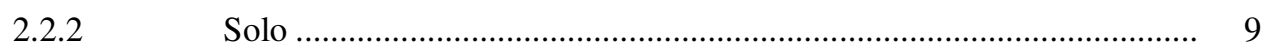

2.3 Tolerância das plantas ao sódio ......................................................... 11

2.4 O uso de águas residuárias na agricultura .................................................. 13

3 MATERIAL E MÉTODOS .................................................................. 15

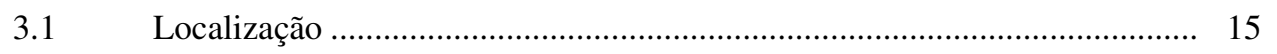

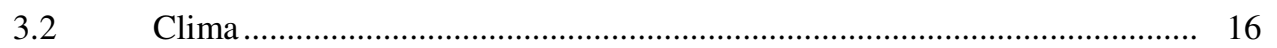

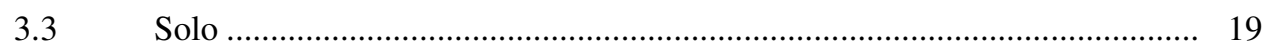

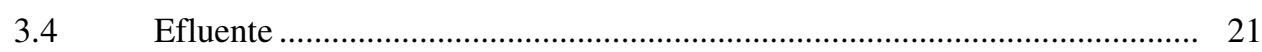




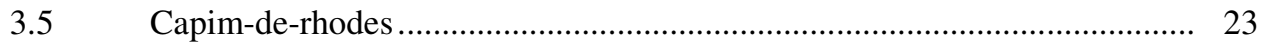

3.6 Caracterização do experimento com o Capim-de-rhodes ............................ 23

3.6.1 Características da área do experimento............................................... 23

3.6.2 Delineamento experimental, tratamentos e análises estatísticas .......... 25

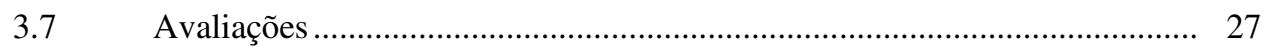

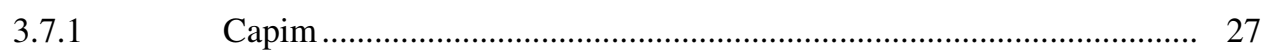

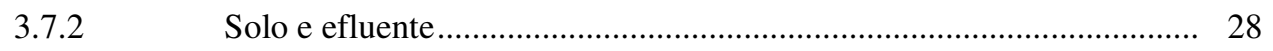

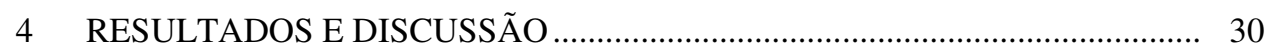

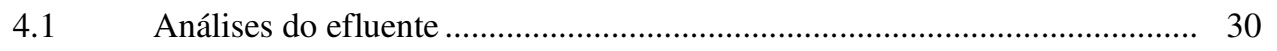

Produção de massa do Capim-de-rhodes .................................................... 33

4.3 Análises foliares e exportação de $\mathrm{Na}, \mathrm{K}, \mathrm{Ca}, \mathrm{Mg}$ e $\mathrm{N}$.................................. 39

4.4 Monitoramento dos parâmetros do solo ............................................... 51

4.4.1 Monitoramento da Faz. Trindade no período de 2001 a 2002 .............. 51

4.4.2 Monitoramento do solo no período experimental ................................ 52

$4.5 \quad$ Balanço de sódio no sistema .............................................................. 58

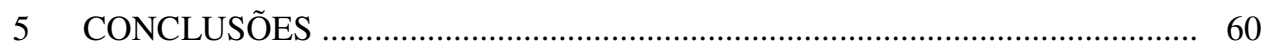

REFERÊNCIAS BIBLIOGRÁFICAS ................................................................ 61 


\section{LISTA DE FIGURAS}

Página

1 Série liotrópica de adsorção de cátions aos colóides do solo .................................. 4

$2 \mathrm{O}$ risco da perda de permeabilidade do solo em relação aos sais das águas de

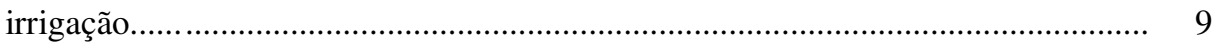

3 Planta baixa da Fazenda Trindade.................................................................... 15

4 Cultivo de pupunha (1) e feno de Capim-de-rhodes (2) ..................................... 16

5 Dados pluviométricos da Fazenda Trindade em 2002 ...................................... 17

6 Dados pluviométricos da Fazenda Trindade em 2003 ......................................... 17

7 Gráfico do balanço hídrico mensal para Matão/SP em 2003 ................................ 18

8 Gráfico do balanço hídrico considerando as irrigações com efluente, durante o período de condução do ensaio........................................................................................ 18

9 Vista da indústria na entrada da fazenda (3) e lagoa de transbordo localizada no ponto

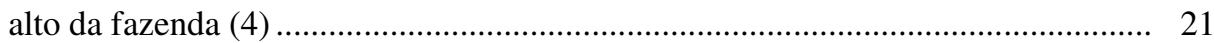

10 Situação do campo na instalação do ensaio - massa remanescente do ciclo anterior...

11 Croqui do ensaio 24

12 Canhão de aspersão em operação com efluente industrial (6) 
13 Gráfico dos volumes de irrigação diários, precipitação e irrigação acumulados... 26

14 Ancinho para corte e quadro com $0,25 \mathrm{~m}^{2}$ para amostragem do capim.................. 28

15 Localização dos pluviômetros, sobre estacas a $1,5 \mathrm{~m}$ do solo

16 Desenvolvimento do Capim-de-rhodes sem fertilizantes (9) e com $50 \mathrm{~kg}^{-h a^{-1}}$ de $\mathrm{N} \mathrm{e}$ $\mathrm{K}_{2} \mathrm{O}(10)$ aos 20 daa. 37

17 Desenvolvimento do capim com 100 (11) e com 200 kg.ha ${ }^{-1}$ de N e $\mathrm{K}_{2} \mathrm{O}$ (12)..... 37

18 Comparativo visual do desenvolvimento do capim sem fertilizante e com $200 \mathrm{~kg} \cdot \mathrm{ha}^{-1}$ de $\mathrm{N}$ e $\mathrm{K}_{2} \mathrm{O}$. 37

19 Comparativo da produção de capim nas duas datas de colheita e quantidade de fertilizante 38

20 Comparação do desenvolvimento do capim, imediatamente antes da colheita em 13 de Outubro.......

21 Evolução dos teores foliares de $\mathrm{Na}$ em função dos tratamentos e datas

22 Interação dos fatores data e tratamento para teor foliar em Na.

23 Evolução dos teores foliares de K em função dos tratamentos e datas

24 Evolução dos teores foliares de Ca em função dos tratamentos e datas

25 Evolução dos teores foliares de Mg em função dos tratamentos e datas

26 Evolução dos teores foliares de $\mathrm{N}$ em função dos tratamentos e datas

27 Evolução dos teores foliares de $\mathrm{P}$ em função dos tratamentos e datas.

28 Evolução dos teores foliares de S em função dos tratamentos e datas. 44 
29 Exportação de $\mathrm{Na}$ em função dos tratamentos e datas .

30 Variação dos teores de Na no solo em função da profundidade (cm), em 26/Agosto, antes da instalação do ensaio

31 Variação do PST no solo em função da profundidade, em 26/Agosto, antes da instalação do ensaio

32 Teores de $\mathrm{Na}$ no solo na profundidade $0-15 \mathrm{~cm}$ ao longo das datas 55

33 Teores de Na no solo na profundidade $15-30 \mathrm{~cm}$ ao longo das datas....... 56

34 Teores de Na no solo na profundidade $30-50 \mathrm{~cm}$ ao longo das datas. 56

35 Teores de Ca no solo de $0-15 \mathrm{~cm}$ de profundidade ao longo das datas...... 57

36 Teores de $\mathrm{K}$ no solo na profundidade $0-15 \mathrm{~cm}$ ao longo das datas..... 57

37 Participação relativa do montante de sódio, restante no solo após o segundo corte do capim, extraído e lixiviado. 59 


\section{LISTA DE TABELAS}

Página

1 Valores de $\mathrm{Ca}_{\mathrm{x}}$ para cálculo da Adj. RAS ........................................................ 6

2 Classes de águas de irrigação ......................................................................... 7

3 Guia de interpretação de qualidade de água de irrigação....................................... 8

4 Tolerância de culturas ao PST ............................................................................ 12

5 Descrição morfológica dos perfis de solo da área experimental .............................. 20

6 Análise química do solo da área experimental..................................................... 20

7 Análises físicas do solo da área experimental............................................... 21

8 Teores de Na+ no efluente em Julho, Agosto e Setembro de 2003 ....................... 22

9 Extração de elementos por braquiária (Brachiaria decumbens) e Capim-de-rhodes

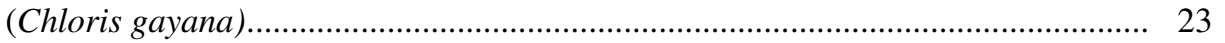

10 Grade de tratamentos do experimento com Capim-de-rhodes ............................ 27

11 Análise do efluente coletado durante as irrigações do experimento ...................... 32

12 Irrigação com o efluente aplicado no experimento, teor de elementos e quantidade resultante aplicada ao solo

13 Determinação da matéria seca remanescente antes da aplicação dos tratamentos.. 34 
14 Produção de Capim-de-rhodes em três cortes mediante doses de fertilizante .....

15 Exportações de $\mathrm{Na}, \mathrm{K}, \mathrm{Ca}, \mathrm{Mg}$ e N (kg.ha $\left.{ }^{-1}\right)$ em função das doses de fertilizante e datas de colheita

16 Comparativo entre total de $\mathrm{Na}, \mathrm{K}, \mathrm{Ca}, \mathrm{Mg}$ e $\mathrm{N}\left(\mathrm{kg}_{\mathrm{h}} \mathrm{ha}^{-1}\right)$ fornecidos e exportados ao final do experimento

17 Evolução dos parâmetros químicos do solo da Fazenda Trindade em duas épocas: setembro de 2001 e maio de 2002

18 Balanço de sódio na área do experimento, considerando o total aplicado, extraído e as análises de solo 58 


\section{LISTA DE ABREVIATURAS E SÍMBOLOS}

Adj. RAS: Relação de adsorção de sódio ajustada

arg.: argilosa

CE: condutividade elétrica

CTC: capacidade de troca de cátions

Daa: dias após a aplicação

md.arg.: média argilosa

md-ar.: média arenosa

MS: matéria seca

PST: porcentual de sódio trocável

RAS: relação de adsorção de sódio

$\mathrm{S}$ : soma de bases

Trat.: tratamento

V\%: saturação por bases 


\title{
REMEDIAÇÃO DE UM ARGISSOLO VERMELHO AMARELO DISTRÓFICO IRRIGADO COM EFLUENTE INDUSTRIAL CITRÍCOLA COM O CULTIVO DO CAPIM-DE-RHODES (Chloris gayana, Kunth)
}

\author{
Autor: MARCOS DE FERRAN
}

Orientador: Prof Dr. JAIRO ANTONIO MAZZA

\section{RESUMO}

Com o objetivo de utilizar o Capim-de-rhodes como ferramenta de remediação de um Argissolo, textura média, irrigado com efluente industrial, um ensaio foi realizado em condições de campo no município de Matão (Estado de São Paulo), a fim de se verificar a capacidade de exportação de $\mathrm{Na}$ pelo Capim, sob diferentes doses de fertilizantes, nitrogenado e potássico. O experimento foi instalado no final da estação seca, em parcelas de $6 \times 7 \mathrm{~m}$, com desenho experimental de blocos totalmente casualizados. Os tratamentos foram: testemunha total (solo nu) e cultivo de capim com 0, 50, 100 e $200 \mathrm{~kg}$ de $\mathrm{N}$ e $\mathrm{K}_{2} \mathrm{O} \cdot \mathrm{ha}^{-1}$, aplicados a cada corte do capim (40 dias de intervalo). Foram realizadas coletas de solo em três profundidades, antes da aplicação dos tratamentos e depois, juntamente com as duas colheitas de capim; estas últimas visando a avaliação do rendimento agrícola e diagnose foliar. Os resultados indicaram uma nítida resposta em termos de produção de massa seca e teor de sódio na parte aérea quando o capim foi submetido às doses de 50,100 e $200 \mathrm{~kg}$ de $\mathrm{N} \mathrm{e} \mathrm{K}_{2} \mathrm{O}^{-\mathrm{ha}^{-1}}$, 
comparado com o tratamento sem fertilizante. Esta resposta levou o capim a uma capacidade total de exportação de sódio de $120 \mathrm{~kg} \cdot \mathrm{ha}^{-1}$, quantidade esta, maior do que a aplicada pela irrigação no período do ensaio $\left(75 \mathrm{~kg} \cdot \mathrm{ha}^{-1}\right)$, levando à redução do teor no solo. O Capim-de-Rhodes demonstrou sua utilidade potencial como remediador de solos solódicos. Os resultados indicaram que é possível a prática da irrigação com o efluente, manejando-se adequadamente o capim, principalmente com fertilizantes nitrogenados, indicando também melhoria das características químicas do solo. 


\title{
REMEDITION OF A TIPIC HAPLUDULT IRRIGATED WITH ORANGE JUICE INDUSTRY WASTE WATER TROUGH Chloris gayana (Kunth) PLANTATION
}

\author{
Author: MARCOS DE FERRAN
}

Adviser: Prof. Dr. JAIRO ANTONIO MAZZA

\section{SUMMARY}

With the objective of using Chloris gayana (a grass specie) as a tool on the remediation of a tipic Hapludult, medium texture, irrigated with industrial waste water, a field trial was installed in Matão (state of São Paulo, Brazil) in order to assess the total exportation capacity of sodium by the grass, under different rates of nitrogen and potassium. The experiment was carried out at the end of the dry season, on $6 \times 7$ meters plot on a randomized complete block design. The treatments were: untreated (nude soil), and grass fertilized with $0,50,100 \& 200 \mathrm{~kg}$ of $\mathrm{N}$ and $\mathrm{K}_{2} \mathrm{O} \mathrm{ha}^{-1}$, applied at each grass harvesting event (40 days interval). Soil was collected at three depths, before treatment application, and after, together with both grass harvesting; those, with the objective of evaluating yield and foliar analysis. The results indicated a clear response of yield and leaf sodium content when the grass was submitted to $50,100 \& 200 \mathrm{~kg}^{-h^{-1}}$ of $\mathrm{N}$ and $\mathrm{K}_{2} \mathrm{O}$, compared to the zero fertilizer treatment. The grass achieved $120 \mathrm{~kg} \cdot \mathrm{ha}^{-1}$ exportation capacities in 80 days, which is more than the amount of sodium applied by the irrigation (75 kg.ha-1). Chloris gayana, showed its utility as a potential bio 
remediator of sodic soils. Also, the results confirmed that is possible to use the soil as a tool to treat waste water containing sodium, by managing adequately the mentioned grass specie, mainly with nitrogen fertilizer, maintaining quality for production. 


\section{INTRODUÇÃO}

A revolução industrial atinge cerca de 200 anos no mundo e, no Brasil, apenas cerca de 100 anos. Este período trouxe, indubitavelmente, grande desenvolvimento para a humanidade, entretanto trouxe também à tona uma preocupação que tem sido discutida intensamente pelo menos nos últimos 20 anos. Trata-se da exploração do ambiente e dos seus recursos naturais renováveis e não renováveis. Especificamente, o solo é considerado um recurso natural não renovável, considerando-se o tempo necessário para sua formação como substrato para sustentação e desenvolvimento das plantas superiores.

Tendo em vista este conceito, pesquisas envolvendo a utilização de solos como alternativa para destinação de resíduos domésticos ou industriais têm sido conduzidas para viabilizar esta modalidade, objetivando-se no mínimo manter o potencial produtivo do solo ou até melhorá-lo, pela adição de nutrientes de plantas.

O presente estudo foi desenvolvido na Citrosuco, empresa fabricante de suco de laranja concentrado, localizada no município de Matão - SP. Seu processo industrial gera grande volume de efluente contendo sódio $(\mathrm{Na})$, oriundo da assepsia das máquinas. Historicamente, o teor de $\mathrm{Na}$ estava entre 200 e $300 \mathrm{ppm}$, mas iniciativas recentes da empresa na recuperação de soda cáustica antes do descarte do efluente permitiram reduzir o teor médio para valores ao redor de $50 \mathrm{ppm}$. Seu descarte final se faz pelo bombeamento para uma área rural, onde é aspergido sobre o solo para cultivo de pupunha e produção de feno.

O objetivo da dissertação em questão é avaliar a utilização do Capim-de-rhodes (Chloris gayana, Kunth) como organismo controlador do teor de Na num Argissolo 
utilizado para destinação dos efluentes industriais da fábrica de suco de laranja concentrado.

A hipótese experimental é de que a exportação de Na pelo capim manejado com fertilizantes nitrogenado e potássico permite extrair mais $\mathrm{Na}$ do solo do que o aplicado pela irrigação. Portanto, supõe-se que a prática de destinação do efluente no solo cultivado com o capim seja viável. 


\section{REVISÃO DE LITERATURA}

\subsection{Comportamento e efeitos do sódio no solo}

A formação dos solos sob clima tropical úmido baseia-se na retirada de bases em função do elevado grau de intemperismo causando a acidificação do meio. Contrariamente, solos salinos formam-se pelo acúmulo de sais, entre eles o $\mathrm{Na}$ (Raij, 1991). O processo de salinização é comum em regiões de clima semi-árido, onde as chuvas não são suficientes para remover os sais do solo (Marschner, 1995). A água de irrigação pode trazer consigo certa concentração de sais que pode agravar a salinização, principalmente quando aliada à ausência de lixiviação (Raij, 1991), e quando a quantidade adicionada (somando-se as precipitações) não for maior que a evapotranspiração (Bouwer \& Chaney, 1974). A lixiviação é um importante fator que ameniza problemas de salinidade, podendo exceder as quantidades de sais adicionadas por irrigação (Ayers \& Westcot, 1985).

O sódio apresenta comportamento similar ao potássio e nas soluções naturais (solução no solo) ocorre na forma trocável. O íon é facilmente lixiviado e sob o clima tropical úmido é menos abundante de que o potássio (Raij, 1991).

Segundo Tan (1993), a capacidade de adsorção dos cátions aos colóides do solo depende da eletronegatividade do mesmo, da valência do cátion e do raio hidrodinâmico (ou raio iônico do íon hidratado). Quanto maior a eletronegatividade dos colóides, que varia em função da mineralogia do solo, maior será a adsorção de cátions bivalentes. Solos com predomínio de minerais de argila 2:1, por exemplo, ocasionarão forte adsorção de cátions trivalentes (ex.: Al). 
O grau de hidratação do cátion é fundamental na determinação da preferência da adsorção. As séries liotrópicas descritas por Gast (1977), Taylor \& Aschcroft (1972), citadas por Tan (1993), organizam os cátions em ordem decrescente de força de adsorção aos colóides do solo. Quanto maior o raio hidratado do cátion, menor será a força de adsorção aos colóides (Figura 1).

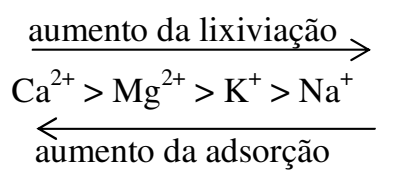

Figura 1 - Série liotrópica de adsorção de cátions aos colóides do solo

O acúmulo de Na pode ocorrer sob certas circunstâncias, causando mudanças físicoquímicas indesejáveis ao solo, particularmente à sua estrutura. $\mathrm{O} \mathrm{Na}^{+}$tem a habilidade de dispersar as argilas, quando presente acima de um determinado teor, relativo à concentração total de sais dissolvidos. Sua presença nos sítios de troca dos minerais de argila reduz a atração entre as partículas do solo, ocasionando a dispersão. A dispersão de argilas resulta na destruição da estrutura do solo e em uma redução nas taxas de infiltração de água e ar no solo (Feigin et al., 1991). As partículas dispersas movem-se pelo solo ocupando os espaços porosos e, quando seco, formam-se crostas que são um impedimento à mecanização e interferem na germinação e emergência de plântulas. (Irvine \& Reid, 2001).

Em solos sódicos os processos primários responsáveis pela degradação física são a expansão das argilas em níveis relativamente altos e a dispersão devido à alteração do PST do solo (Sumner, 1993; Halliwell et al., 2001). O grau de expansão e dispersão de argilas do solo depende da natureza do mineral de argila predominante. Maior sensibilidade para esses processos ocorre para a montmorilonita, sensibilidade moderada para a ilita e menor sensibilidade para a caulinita (Feigin et al., 1991).

Aloisi (1995) não verificou mudança na condutividade hidráulica do solo, mesmo com aumento da quantidade de argila dispersa em água, em áreas que receberam resíduo da indústria citrícola por vários anos. 


\subsection{Parâmetros de avaliação dos efeitos do $\mathrm{Na}$}

\subsection{1 Águas de irrigação}

Feigin et al. (1991) mencionam que as águas de irrigação podem apresentar características em sua composição que contribuem para aumento dos riscos de sodificação de solos. Entre elas destacam-se a concentração total de sais, a concentração dos íons $\mathrm{Na}$ pelos efeitos tóxicos diretos ou indiretos às plantas, incluindo desequilíbrio nutricional, e a concentração de $\mathrm{HCO}_{3}{ }^{-}$, que juntamente com o $\mathrm{Na}$ podem resultar na deterioração da estrutura do solo e conseqüentemente na redução da permeabilidade.

No caso de esgotos domésticos ou industriais, os teores de $\mathrm{Na}$ podem variar entre

100 e $800 \mathrm{mg} \mathrm{l}^{-1}$. Em alguns casos, mesmo em concentrações relativamente baixas, os sais adicionados são suficientes para alterar a qualidade da água, do ponto de vista da aplicação em solo agrícola (Feigin et al., 1991). A irrigação com efluente comumente resulta em incremento da sodicidade devido à média e alta salinidade e altas concentrações de sódio de muitos efluentes (Balks et al., 1998).

$\mathrm{O}$ índice mais comumente utilizado para avaliação do risco do $\mathrm{Na}$ nas águas de irrigação é a RAS ou SAR (sodium adsortion ratio), dado pela seguinte fórmula:

$$
R A S=\frac{[N a]}{\sqrt{\frac{[C a]+[M g]}{2}}}
$$

Onde,

[ ] - concentrações iônicas expressas em mmol.1 $1^{-1}$

Águas de RAS baixa tendem a provocar menores efeitos de dispersão de argilas no solo e, portanto, pouca ou nenhuma interferência na permeabilidade e aeração, por apresentar melhor equilíbrio entre $\mathrm{Na}$ e $\mathrm{Ca}+\mathrm{Mg}$, pelo efeito agregador nos colóides apresentado pelos cátions bivalentes. 
Valores de RAS elevados (>10) indicam que poderá haver problemas sérios de dispersão de argilas no solo, entretanto, em alguns solos pode ser admitido valor superior a 15 sem maiores problemas, segundo trabalhos citados por Paganini (1997).

A RAS ajustada (Adj. RAS) deve ser considerada para se entender o equilíbrio $\mathrm{Na}^{+}$ e $\mathrm{Ca}+\mathrm{Mg}$ no solo, após a irrigação com efluente, considerando a alcalinidade da água, que pode potencializar o efeito nocivo do $\mathrm{Na}^{+}$no solo. $\mathrm{Em} \mathrm{pH}$ elevado, pode ocorrer a precipitação do Cálcio que age como floculador de argilas em contrapartida ao efeito dispersante do Na. Em valores de pH entre 7,5 e 8,2 o Ca pode precipitar no solo na forma de $\mathrm{CaCO}_{3}$, aumentando o efeito negativo relativo do $\mathrm{Na}$ (Bouwer \& Chaney, 1974). Em valores de pH abaixo de 8,4 há predominância do íon bicarbonato $\left(\mathrm{HCO}_{3}{ }^{-}\right)$, enquanto acima desse valor predomina o íon carbonato $\left(\mathrm{CO}_{3}{ }^{2-}\right)$ (Feigin et al., 1991).

$$
\operatorname{Adj.RAS}=\frac{[\mathrm{Na}]}{\sqrt{\frac{C a_{X}+[\mathrm{Mg}]}{2}}}
$$

Onde,

[ ] - concentrações iônicas expressas em mmol..$^{-1}$

$C a_{x}$ - obtido através de tabela levando-se em consideração a condutividade elétrica (CE) e a relação $\mathrm{HCO}_{3}^{-} /$[Ca] (Tabela 1).

Tabela 1 . Valores de $\mathrm{Ca}_{\mathrm{x}}$ em função da $\mathrm{CE}$ e relação $\mathrm{HCO}_{3} / \mathrm{Ca}$

\begin{tabular}{|c|c|c|c|c|c|c|c|c|c|c|c|c|}
\hline \multirow[b]{2}{*}{$\mathrm{HCO}_{3} / \mathrm{Ca}$} & \multicolumn{12}{|c|}{ 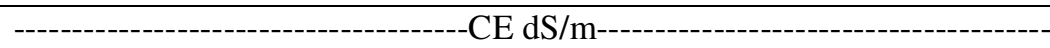 } \\
\hline & 0,1 & 0,2 & 0,3 & 0,5 & 0,7 & 1,0 & 1,5 & 2,0 & 3,0 & 4,0 & 6,0 & 8,0 \\
\hline & \multicolumn{12}{|c|}{$\mathrm{Ca}_{\mathrm{x}}$} \\
\hline 4,00 & 0,71 & 0,73 & 0,75 & 0,78 & 0,80 & 0,82 & 0,86 & 0,88 & 0,93 & 0,97 & 1,03 & 1,07 \\
\hline 4,50 & 0,66 & 0,68 & 0,69 & 0,72 & 0,74 & 0,76 & 0,79 & 0,82 & 0,86 & 0,90 & 0,95 & 0,99 \\
\hline 5,00 & 0,61 & 0,63 & 0,65 & 0,67 & 0,69 & 0,71 & 0,74 & 0,76 & 0,80 & 0,83 & 0,88 & 0,93 \\
\hline 7,00 & 0,49 & 0,50 & 0,52 & 0,53 & 0,55 & 0,57 & 0,59 & 0,61 & 0,64 & 0,67 & 0,71 & 0,74 \\
\hline 10,00 & 0,39 & 0,40 & 0,41 & 0,42 & 0,43 & 0,45 & 0,47 & 0,48 & 0,51 & 0,53 & 0,56 & 0,58 \\
\hline 20,00 & 0,24 & 0,25 & 0,26 & 0,26 & 0,27 & 0,28 & 0,29 & 0,30 & 0,32 & 0,33 & 0,35 & 0,37 \\
\hline
\end{tabular}

Fonte: adaptado de EPA Austrália (1991). 


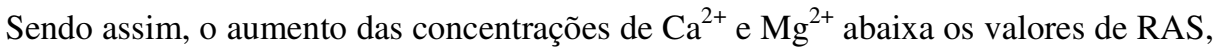
melhorando a qualidade do efluente e da água de irrigação. Já os íons $\mathrm{HCO}_{3}{ }^{-}$e $\mathrm{CO}_{3}{ }^{2-}$ podem aumentar os riscos de sodicidade da água de irrigação por causarem a precipitação de carbonato de cálcio $\left(\mathrm{CaCO}_{3}\right)$ (Feigin et al., 1991).

Paganini (1997) menciona que também a salinidade das águas de irrigação deve ser observada. A salinidade pode ser determinada pela condutividade elétrica (CE), que é diretamente relacionada à concentração de sais solúveis. $\mathrm{A} C \mathrm{CE}$ da água medida a $25^{\circ} \mathrm{C}$ é expressa em deci-Siemens por metro $(\mathrm{dS} / \mathrm{m})$, ou micro-Siemens por centímetro $(\mu \mathrm{S} / \mathrm{cm})$ ou milimós por centímetro (mmhos/cm). Os valores de CE são convertidos para mg/l do total de sais dissolvidos (TDS) no líquido, utilizando-se os fatores:

$\begin{aligned} \operatorname{TSD}(\mathrm{mg} / \mathrm{l}) & =\mu \mathrm{S} / \mathrm{cm} \times 0,64 \\ \operatorname{TSD}(\mathrm{mg} / \mathrm{l}) & =\mathrm{dS} / \mathrm{m} \times 640 \\ \operatorname{TSD}(\mathrm{mg} / \mathrm{l}) & =\mathrm{mmhos} / \mathrm{cm} \times 640\end{aligned}$

A Tabela 2 mostra as classes de águas de irrigação segundo EPA - Austrália (1991).

Tabela 2 . Classes de águas de irrigação

\begin{tabular}{ccccc}
\hline Classe & Interpretação da salinidade & $\begin{array}{c}\text { TSD } \\
(\mathrm{mg} / \mathrm{l})\end{array}$ & $\begin{array}{c}\mathrm{CE} \\
(\mathrm{mS} / \mathrm{cm})\end{array}$ & $\begin{array}{c}\mathrm{CE} \\
(\mathrm{dS} / \mathrm{m})\end{array}$ \\
\hline 1 & Baixa & $0-125$ & $0-270$ & $0-0,3$ \\
2 & Média & $125-500$ & $270-280$ & $0,3-0,8$ \\
3 & Alta & $500-1500$ & $780-2340$ & $0,8-2,3$ \\
4 & Muito alta & $1500-3500$ & $2340-5470$ & $2,3-5,5$ \\
5 & Extremamente alta & $>3500$ & $>5470$ & $>5,5$ \\
\hline
\end{tabular}

Fonte: EPA Austrália (1991).

Onde,

Classe1: pode ser utilizada pela maioria das plantações e dos tipos de solo, com qualquer tipo de disposição de esgotos no solo, com pequena probabilidade do problema da salinidade vir a desenvolver-se. Alguma dissolução/lixiviação pode ser requerida, mas isso ocorre com a prática normal da irrigação, exceto em solos com permeabilidade extremamente baixa. 
Classe 2: pode ser utilizada se ocorrer uma moderada dissolução/lixiviação. Plantas com moderada tolerância à salinidade podem desenvolver-se, usualmente, sem práticas especiais de controle da salinidade. Quando aplicadas por aspersão pode ocorrer "queimaduras" nas folhas, principalmente nos períodos mais quentes.

Classe 3: as águas mais próximas do limite superior deste grupo não podem ser utilizadas em áreas que apresentem restrições quanto à drenagem. Rigor específico deve ser aplicado na definição da espécie a ser irrigada.

Classe 4: para a disposição, os solos devem ser permeáveis e com drenagem adequada. A irrigação deve ser feita em excesso, para proporcionar considerável dissolução/lixiviação, e a vegetação selecionada deve ser tolerante aos sais.

Classe 5: não apropriada para irrigação, exceto em solo com alta permeabilidade e muito boa drenagem, sob um acompanhamento rigoroso, especialmente no que diz respeito à dissolução/lixiviação. Utilização restrita à vegetação com alta tolerância aos sais ou, ocasionalmente, em caso de emergência.

O gráfico da Figura 2 avalia o risco de perda de permeabilidade do solo em função da RAS Ajustada e da CE da água de irrigação.

Segundo Ayers \& Westcot (1985) as águas de irrigação, de acordo com a RAS e a $\mathrm{CE}$, podem ser classificadas segundo o grau de restrição ao uso relativo à salinidade, potencial de alteração da infiltração de água no solo e finalmente quanto à toxicidade específica do $\mathrm{Na}$ (Tabela 3).

Tabela 3 . Guia de interpretação de qualidade da água de irrigação

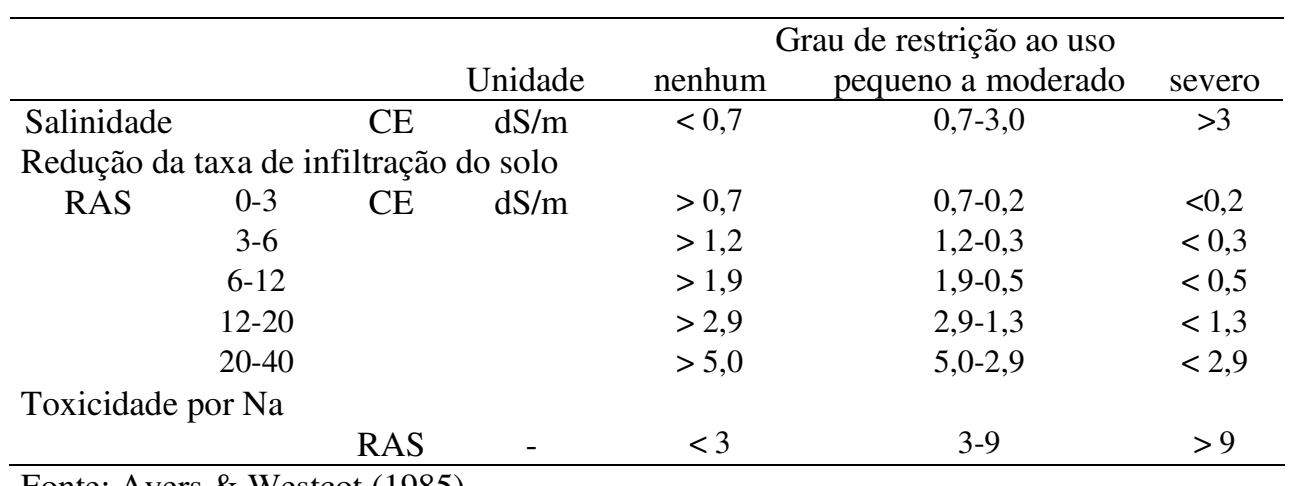

Fonte: Ayers \& Westcot (1985) 


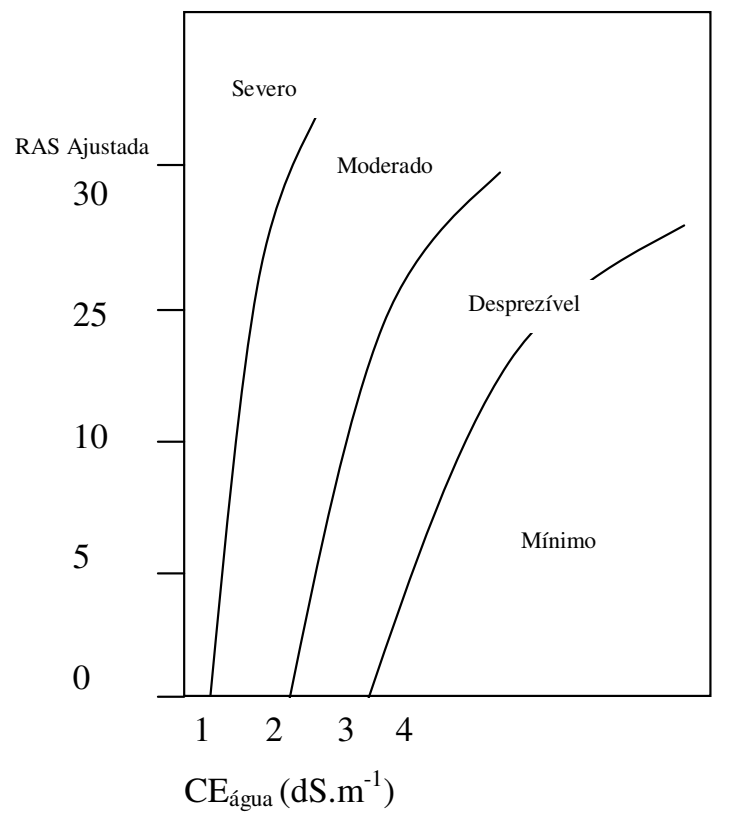

Figura 2 - O risco da perda de permeabilidade do solo em relação aos sais das águas de irrigação. Fonte: EU-EPA (1981)

\subsubsection{Solo}

Meurer (2000) define a PST (porcentagem de sódio trocável) que indica a saturação do complexo de troca do solo pelo íon sódio. É obtida pela relação entre o teor do sódio trocável e a CTC do solo:

$$
P S T=\frac{N a}{C T C \times 100}
$$

Onde,

- $N a$ = sódio trocável ou adsorvido, em mmol $\mathrm{cm}^{-3}$ ou mmol $\cdot \mathrm{kg}^{-1}$;

- $C T C=$ capacidade de troca de cátions do solo $\left(\mathrm{Ca}^{+}, \mathrm{Mg}^{+}, \mathrm{Na}^{+}, \mathrm{K}^{+}, \mathrm{Al}^{3+}\right.$ e $\left.\mathrm{H}^{+}\right)$, em mmol $\mathrm{c}_{\mathrm{dm}} \mathrm{m}^{-3}$ ou $\mathrm{mmol}_{\mathrm{c}} \cdot \mathrm{kg}^{-1}$. 
Chirinos (1992) concluiu, em dissertação de mestrado com experimento em casa de vegetação, que se deve considerar o efeito de incremento do PST e conseqüentemente a redução da condutividade hidráulica, ao se utilizar o solo para descarte de um resíduo que contenha $\mathrm{Na}^{+}$. O limite crítico de teor de $\mathrm{Na}^{+}$(PST) depende do tipo de solo. A lavagem do solo por água provoca diminuição de $\mathrm{Na}^{+}$dos colóides e, portanto, mesmo que o PST atinja valores altos e, conseqüentemente, baixa condutividade hidráulica, tal efeito pode ser revertido pela lavagem. Ainda, a adição de resíduos contendo sódio pode ser feita aproveitando-se a época das chuvas.

Quanto à presença de sódio no solo, o Sistema Brasileiro de Classificação de Solos (1999) qualifica o mesmo como:

a) sódico: quando em um horizonte ou camada se encontrar saturação por sódio $\left(100 \times \mathrm{Na}^{+} / \mathrm{CTC}\right) \geq 15$ (derivado dos EUA, 1954).

b) solódico: quando em um horizonte ou camada se encontrar saturação por sódio $\left(100 \mathrm{x} \mathrm{Na}^{+} / \mathrm{CTC}\right)>6 \mathrm{e}<15$ (derivado de FAO, 1974).

Estes critérios, adaptados de pesquisas nos EUA e outros locais, mostram-se úteis para classificação, porém não concluem imediatamente que existam problemas de utilização de solos que expressem um caráter ou outro.

Valores limites de PST que causam deterioração da estrutura do solo podem variar. Em solos australianos, por exemplo, onde a adsorção de sódio nas superfícies das argilas excede $6 \%$ da capacidade de troca de cátions do solo (PST $\geq 6$ ), o solo é considerado sódico e está sujeito a degradações estruturais. O PST de valor 6 é baixo comparado com o valor 15 adotado pelo Laboratório de Salinidade dos Estados Unidos como indicador de deterioração da estrutura do solo (Rengasamy \& Olsson, 1991). Sumner (1993) relata que o valor de PST > 15 adotado pelo Laboratório de Salinidade dos Estados Unidos foi baseado em medições de condutividade hidráulica utilizando água com concentração eletrolítica total muito elevada (3-10 mmol $\left._{c} l^{-1}\right)$ comparada à concentração eletrolítica da água utilizada em estudos australianos $\left(<0,7\right.$ mmol $\left._{\mathrm{c} .} \mathbf{l}^{-1}\right)$. 


\subsection{Tolerância das plantas ao sódio}

Russel (1973) afirma que o papel exato do sódio nas plantas não é bem definido e, embora não seja essencial às plantas, pode exercer o papel do potássio ou substituí-lo parcialmente. Marschner (1995) confirma esta informação, sobretudo para plantas de ciclo C4 (gramíneas), e ainda menciona que o Na pode ser desejável para certas culturas, como, por exemplo, a beterraba açucareira. Em certas regiões, a aplicação de sódio em adubação de forrageiras tem sido considerada útil para aumentar o teor do elemento nas folhas e por melhorar a aceitabilidade da forragem pelo animal, resultando em maior consumo (Raij, 1991).

Gorhan, J. (1995) afirma que a tolerância de plantas à salinidade pode ser encontrada em espécies de um grande número de famílias. Certa variedade de mecanismos está envolvida na adaptação destas plantas para viver em ambientes de alto teor de sódio. A planta deve acumular solutos para manter um gradiente de potencial hídrico entre ela e o solo, para que haja diferença de potencial e que a água possa penetrar na planta mediante a transpiração. Caso a diferença de potencial não seja mantida, a água fluirá para o sentido oposto, ou seja, de dentro da planta para o solo.

Diversos fatores, desde o genótipo até a composição química do solo e condições climáticas, influenciam na absorção de sódio pelas plantas. Alternativamente pode-se escolher a cultura apropriada para as condições de solo locais e as necessidades de produção.

Silva, M.J (1978) menciona que de maneira geral a maioria das culturas é sensível ao sal durante as fases de germinação e crescimento das plântulas.

A tolerância de plantas ao sódio é uma característica que pode ser aproveitada para recuperação de solos sódicos. Elgabey \& Wiklander, citados por McLean (1956), concluíram, a partir de ensaios com ervilha e cevada, que as diferenças de absorção relativa entre cálcio e sódio relaciona-se com a capacidade de troca das raízes. Bower \& Wacleigh (1948) verificaram que o acúmulo de sódio na parte aérea das plantas está estreitamente ligado à tolerância delas ao sódio. Por exemplo, a cultura da beterraba só foi afetada negativamente quando o PST atingiu 60. 
Hayward \& Waldleigh (1949) observaram que todas as variedades de algodão estudadas em meio salino artificial ajustado à pressão osmótica de 4,5 atmosferas cresceram bem, desde que bem irrigadas e fertilizadas.

McNeal et al. (1966) afirmaram que na recuperação de solos sódicos as culturas extratoras de sódio demonstram seu efeito benéfico, não pela reação do $\mathrm{CO}_{2}$ produzido pelas raízes com o $\mathrm{CaCO}_{3}$, mas principalmente devido à assimilação deste pela planta e ao fato de as raízes favorecerem uma melhor condição de condutividade hidráulica, que permite melhor lixiviação do sódio.

Consta da Tabela 4 a tolerância de certas culturas à porcentagem de sódio trocável (PST), segundo Allison (1964).

Tabela 4 . Tolerância de culturas ao PST

\begin{tabular}{lcl} 
Sensibilidade & Variação da PST & Cultura \\
\hline Muito sensíveis & $2-10$ & frutíferas caducas \\
& & Nozes \\
& Citrus \\
& & Abacate \\
Sensíveis & $10-20$ & Feijões \\
Moderadamente & & Trevo \\
tolerantes & $20-40$ & Aveia \\
& & Arroz \\
Tolerantes & & Trigo \\
& & Algodão \\
& $40-60$ & Beterraba \\
Muito tolerantes & & açucareira \\
\end{tabular}




\subsection{O uso de águas residuárias na agricultura}

Os efluentes industriais e domésticos têm como destino tradicional as águas superficiais, depois de passarem por tratamentos preliminares a fim de retirar parte da carga poluidora. Entretanto, o rigor das legislações ambientais sobre a qualidade da água para proteção da saúde humana e do ambiente, juntamente à necessidade da garantia do suprimento de água, tem levado a uma reavaliação deste conceito histórico (VazquezMontiel et al., 1996).

A vantagem do descarte de efluentes tratados em rios é a manutenção do fluxo de água, destinada a consumo à jusante do ponto de descarga. Porém, a prática pode causar a eutrofização dos rios (causada pelo desequilíbrio de nutrientes e proliferação excessiva de algas); deste modo, a alternativa de disposição de efluentes no solo tem ganhado popularidade (Bond, 1998; Halliwell et al., 2001).

Portanto, alternativas têm sido propostas, como o uso de efluentes diversos na agricultura, sendo prática comum em muitos países, fazendo parte de programas governamentais de irrigação e gestão de recursos hídricos, como é o caso de Israel, Egito, Austrália, Arábia Saudita, Tunísia e Chile (Pescod, 1992). No Brasil não há regulamentação específica para o reuso de efluentes nesta modalidade, que pode, entre outros benefícios, transformar uma problemática poluidora em um recurso econômico e ambientalmente seguro (Hespanhol, 2002).

Hespanhol (2002) ainda defende que a agricultura necessitará de novas fontes de suprimento de água, para melhor gestão dos recursos hídricos, sob o risco da não sustentabilidade da produção de alimentos. Oron (1996) conclui sobre a atratividade da destinação de águas residuárias na agricultura, sendo que estas podem ajudar a resolver problemas de falta d'água; assim, grandes quantidades podem ser dispostas anualmente com riscos ambientais mínimos e ainda proporcionar o reaproveitamento de nutrientes. Reconhece-se também que o solo pode completar o tratamento do efluente, funcionando como um filtro, por suas propriedades mineralógicas, físicas, químicas e biológicas.

A presença de elementos essenciais ao desenvolvimento das plantas em efluentes de esgoto tratado é um aspecto favorável em se tratando da irrigação de culturas agrícolas e 
florestais, e indesejável para o lançamento desses resíduos em corpos d'água (Piveli \& Doria, 2003).

Meli, et al. (2002) afirmam que o uso de águas residuárias na agricultura pode afetar a produtividade de culturas, reduzindo a necessidade do uso de fertilização mineral. Isto permite um considerável suprimento de nitrogênio, tanto na forma orgânica como mineral.

Maiores aumentos das concentrações de $\mathrm{NO}_{3}{ }^{-}, \mathrm{Ca}^{+2}$ e $\mathrm{P}$ disponível foram observados por Johns \& McConchie (1994) em camadas superficiais de solos irrigados com efluente de esgoto do que em solos irrigados com água. Porém, aumentos da concentração de $\mathrm{Na}^{+}$ foram observados tanto em camadas superficiais quanto em camadas profundas em tratamentos de irrigação com efluente ou água. Yadav et al. (2002) observaram maior acúmulo de sais em superfície do que em camadas sub-superficiais do solo após irrigação com efluente de esgoto doméstico.

Aloisi (1995) concluiu que o solo pode ser usado como tratamento alternativo aos efluentes da indústria citrícola, desde que observados aspectos de manejo envolvendo o cultivo de espécies adequadas, garantindo a capacidade de produção do solo. 


\section{MATERIAL E MÉTODOS}

\subsection{Localização}

O trabalho foi conduzido na Fazenda Trindade (Figura 3), de propriedade da Empresa Fischer / Citrosuco, no município de Matão-SP. A fazenda tem aproximadamente 400 ha anexos à unidade industrial, onde vem-se desenvolvendo o plantio de pupunha e capim-de-rhodes para produção de feno e utilização em confinamentos de bovinos (Figura 4).

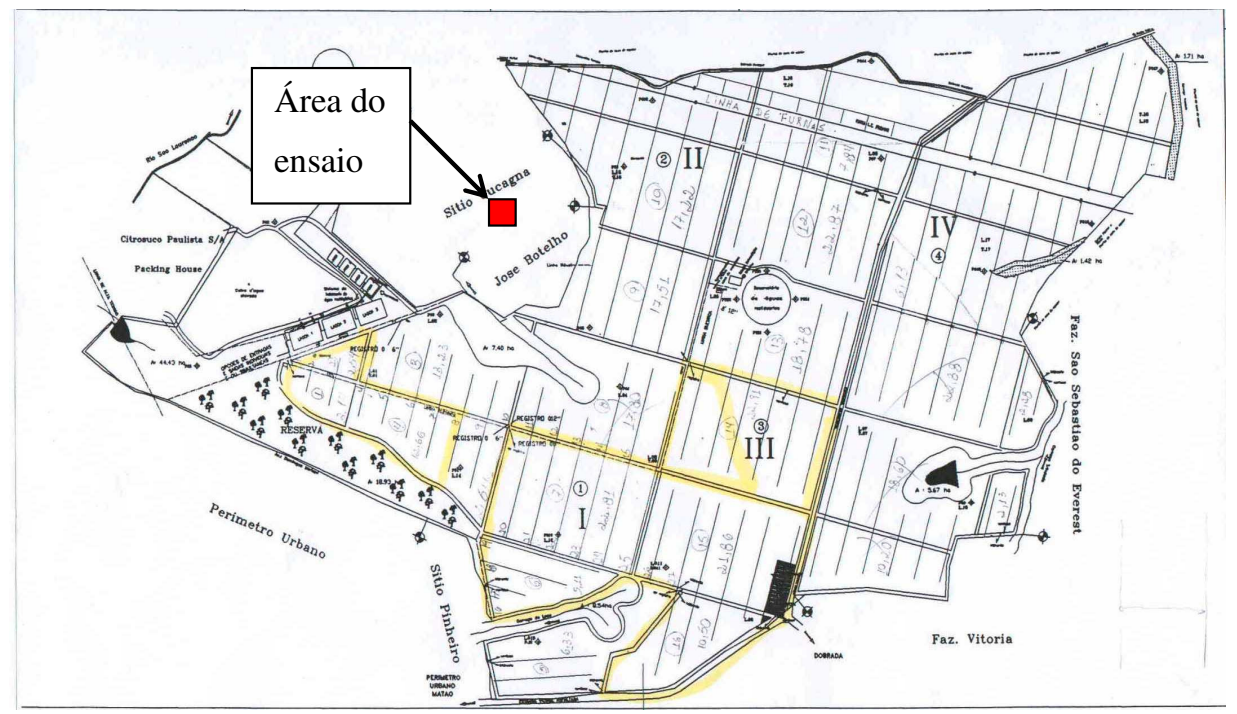

Figura 3 - Planta baixa da Fazenda Trindade 

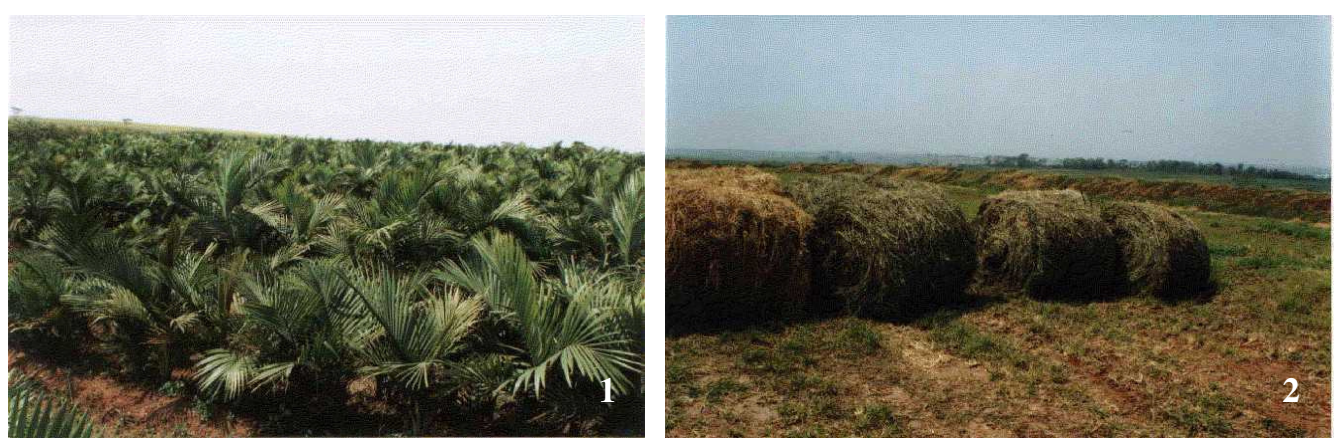

Figura 4 - Cultivo de pupunha (1) e feno de Capim-de-rhodes (2)

\subsection{Clima}

O município de Matão, no Estado de São Paulo, cuja longitude e latitude são respectivamente $48^{\circ} 22^{\prime} \mathrm{O}$ e $21^{\circ} 16^{\prime} \mathrm{S}$, tem clima tropical úmido, com temperatura anual média de $26^{\circ} \mathrm{C}$, e altitude de $555 \mathrm{~m}$ com relação ao nível do mar.

Dados de precipitação dos anos de 2002 e 2003 (Figura 5 e Figura 6), coletados na Fazenda Trindade, mostram valores acumulados de $1.300 \mathrm{~mm}$ anuais, concentrados nos meses de novembro a março, sendo que apenas $150 \mathrm{~mm}$, aproximadamente, ocorreram no período de abril a outubro de 2002.

Na Figura 7 encontra-se o balanço hídrico para a região do município de Matão, calculado pelo método de Thornthwaite \& Mather (1955) citado por Rolim \& Sentelhas (2004). Verifica-se que houve um déficit hídrico a partir de abril até outubro. Com as irrigações de efluente, que se concentraram em setembro, a situação se inverte, configurando-se um excedente de 20,5 e $37,9 \mathrm{~mm}$, respectivamente em outubro e novembro (Figura 8). 


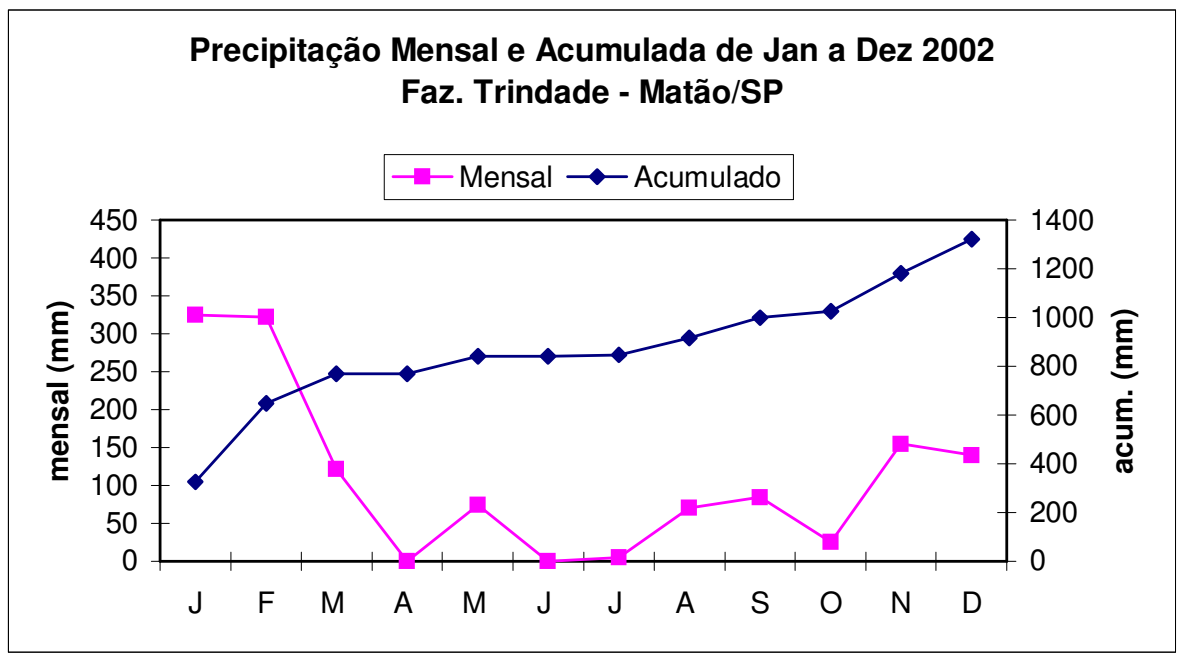

Figura 5 - Dados pluviométricos da Fazenda Trindade em 2002

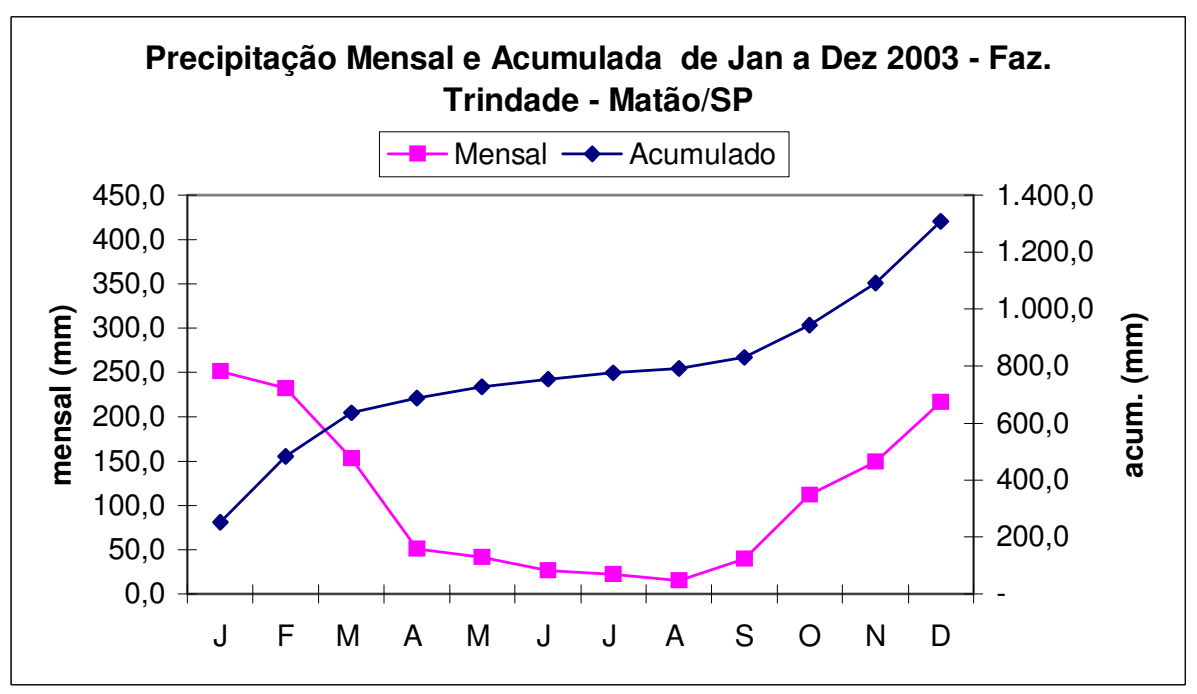

Figura 6 - Dados pluviométricos da Fazenda Trindade em 2003 


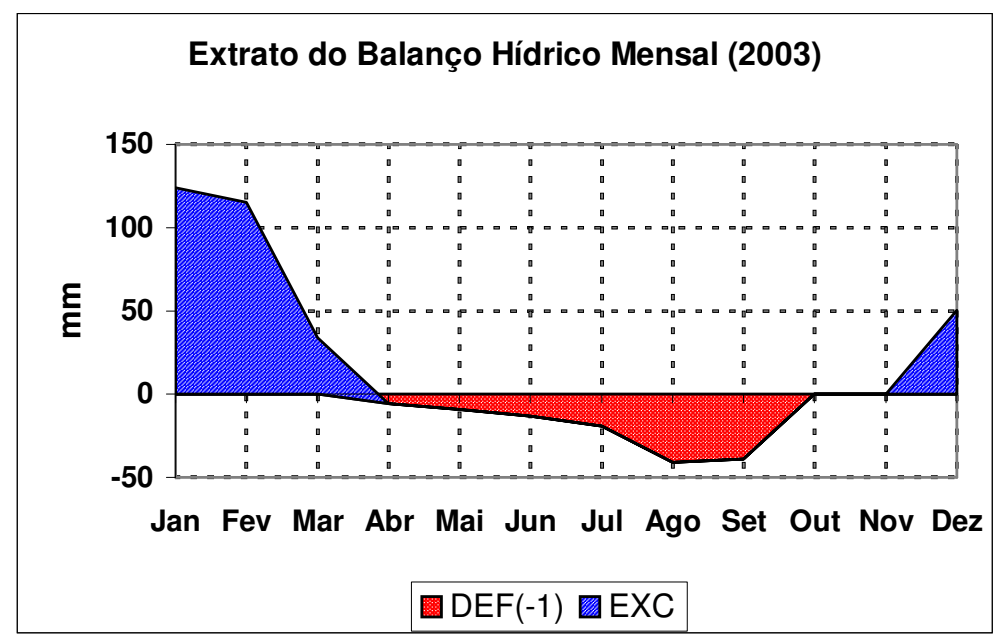

Figura 7 - Gráfico do balanço hídrico mensal para Matão/SP em 2003. Fonte: Rolim $\&$ Sentelhas (2004)

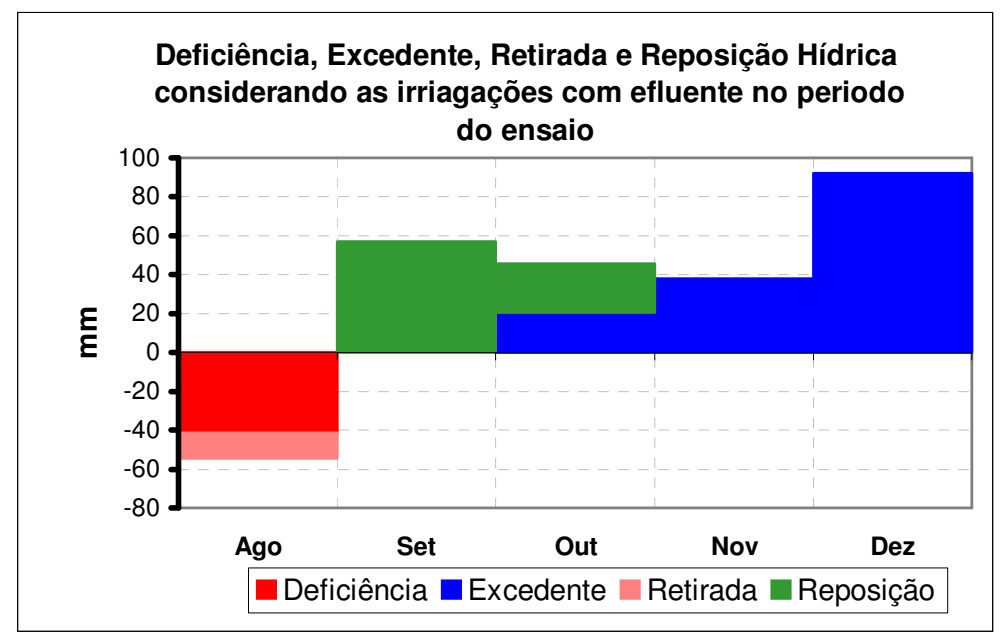

Figura 8 - Gráfico do balanço hídrico considerando as irrigações com efluente, durante o período de condução do ensaio. Fonte: adaptado de Rolim \& Sentelhas (2004) 


\subsection{Solo}

A descrição morfológica dos perfis de solos (Tabela 5) foi realizada adotando-se os procedimentos constantes do manual de Lemos e Santos (1996). Os resultados morfológicos e as análises químicas e físicas permitiram concluir que o solo da área experimental, segundo o Sistema Brasileiro de Classificação de Solos (EMBRAPA, 1999), é um Argissolo Vermelho-Amarelo Distrófico latossólico, cuja definição sintética é: solo com matiz 5YR ou mais vermelho e mais amarelo que 2,5 YR; com saturação por bases menor que $50 \%$, na maior parte dos primeiros $100 \mathrm{~cm}$ do horizonte $\mathrm{B}$; e presença de horizonte B latossólico, abaixo do horizonte B textural, dentro de $200 \mathrm{~cm}$ de profundidade.

$\mathrm{O}$ gradiente textural, calculando-se a razão entre o teor de argila do horizonte $\mathrm{B}$ e o teor de argila do horizonte A (média aritmética de Ap1 e Ap2), é de 1,76, suficiente para caracterização do B textural, segundo o critério da EMBRAPA (1999), que prevê um mínimo de 1,7 para os solos com 15 a 40\% de argila no horizonte A.

A queda do teor de argila no horizonte constante da profundidade de 95 a $100 \mathrm{~cm}$ verificada nas observações morfológicas e comprovadas na análise física (Tabela 7), ocasiona uma redução do gradiente textural para 1,66, somando-se à redução pronunciada do grau da macro agregação, caracterizam tal horizonte como B latossólico.

A Tabela 6 contém os dados médios das análises dos perfis de solos previamente à instalação do experimento ( 26 de agosto). Os resultados obtidos para $\mathrm{Na}$ enquadram o perfil de solo como solódico (EMBRAPA, 1999). Calculando-se o estoque do elemento no perfil até $150 \mathrm{~cm}$ de profundidade, verifica-se a presença de $1207 \mathrm{~kg} \cdot \mathrm{ha}^{-1}$, o que o distingue nitidamente dos perfis modais da região de Matão (clima tropical úmido de altitude, item 3.2).

Quimicamente, o solo se encontrava com boa fertilidade nos horizontes superficiais, com os teores de bases ( $\mathrm{Ca}, \mathrm{Mg}$ e $\mathrm{K}$ ) e $\mathrm{P}$ interpretados como médios, acidez média e saturação por bases alta (Raij, 1991); um bom indicativo de que não haveria grandes limitações ao desenvolvimento do capim no aspecto da fertilidade. 
Tabela 5 . Descrição morfológica dos perfis de solo da área experimental

\begin{tabular}{|c|c|c|}
\hline Horizonte & $\begin{array}{l}\text { Profundidade } \\
\qquad(\mathrm{cm})\end{array}$ & $\begin{array}{l}\text { Descrição: cor, textura, estrutura (tipo e grau), } \\
\text { consistência (seco, úmido e molhado) e transição }\end{array}$ \\
\hline Ap1 & $0-15$ & $\begin{array}{l}5,0 \text { YR 3/3, média arenosa, blocos angulares pequenos, } \\
\text { grau forte, extremamente duro, friável, não plástico e não } \\
\text { pegajoso, transição clara }\end{array}$ \\
\hline Ap2 & $15-30$ & $\begin{array}{l}\text { 5,0 YR 4/4, média, blocos angulares pequenos, grau forte, } \\
\text { muito duro, friável, não plástico e pouco pegajoso, } \\
\text { transição clara }\end{array}$ \\
\hline $\mathrm{Bt}$ & $30-95$ & $\begin{array}{l}\text { 5,0 YR 4/4, média argilosa, blocos subangulares médios, } \\
\text { grau forte, duro, muito friável, pouco plástico e pegajoso, } \\
\text { transição gradual }\end{array}$ \\
\hline Bw & $95-150+$ & $\begin{array}{l}\text { 5,0 YR 4/6, média, blocos subangulares grandes, grau } \\
\text { moderado a fraco, macio, muito friável, não plástico e } \\
\text { não pegajoso. }\end{array}$ \\
\hline
\end{tabular}

Tabela 6 . Análise química do solo da área experimental

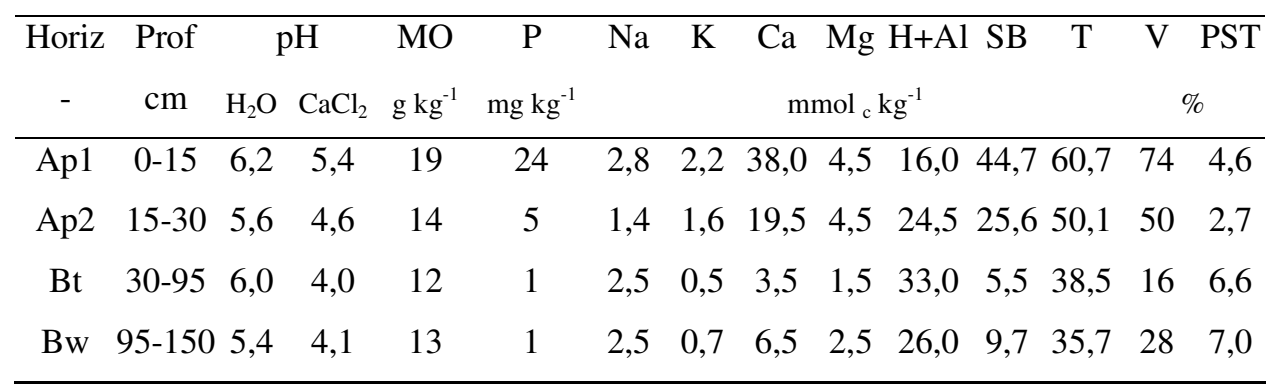


Tabela 7 . Análises físicas do solo da área experimental

\begin{tabular}{|c|c|c|c|c|c|c|c|c|}
\hline \multirow[t]{2}{*}{ Horizonte } & \multirow[t]{2}{*}{ Prof } & \multirow[t]{2}{*}{$\begin{array}{l}\text { Densidade } \\
\text { do solo }\end{array}$} & \multicolumn{5}{|c|}{ G R A N U L O M E T R I A (\%) } & \multirow{3}{*}{$\begin{array}{l}\text { Classe } \\
\text { de } \\
\text { textura }\end{array}$} \\
\hline & & & & Areia & & Silte & Argila & \\
\hline- & $\mathrm{cm}$ & $\mathrm{g} / \mathrm{cm} 3$ & $\mathrm{G}$ & $\mathrm{F}$ & Tot. & & & \\
\hline Ap1 & $0-15$ & 1,6 & 32,0 & 45,0 & 77,0 & 2,0 & 21,0 & md-ar. \\
\hline Ap2 & $15-30$ & 1,7 & 30,0 & 46,0 & 76,0 & 4,0 & 20,0 & md.ar. \\
\hline $\mathrm{Bt}$ & $30-95$ & 1,5 & 27,0 & 34,0 & 61,0 & 3,0 & 36,0 & $\arg$. \\
\hline $\mathrm{Bw}$ & $95-150$ & 1,4 & 26,5 & 36,5 & 63,0 & 3,0 & 34,0 & md.arg. \\
\hline
\end{tabular}

\subsection{Efluente}

Durante o período de processamento de laranja na indústria há geração de cerca de $300 \mathrm{~m}^{3}$ de efluentes industriais por hora, oriundos da concentração do suco e assepsia de máquinas. A alternativa economicamente viável e atualmente praticada para destinação desse resíduo é a aplicação (via irrigação) no solo com a finalidade de produção. Os custos que envolvem o tratamento de um efluente desta natureza são elevados, justificando esta destinação. Na Fazenda Trindade, que se localiza próximo à unidade industrial, é feita a disposição destes efluentes, contando com uma estação de bombeamento e lagoas de transbordo (Figura 9).
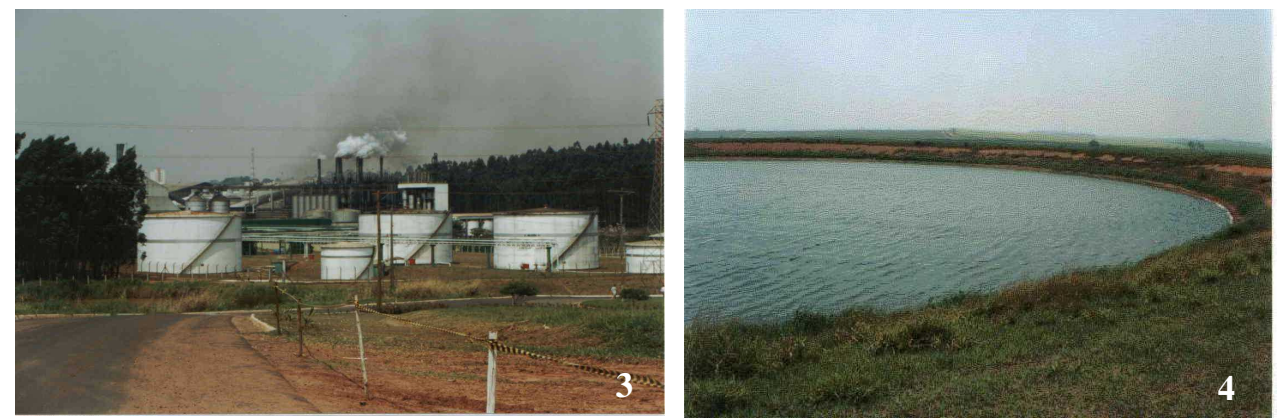

Figura 9 - Vista da indústria na entrada da fazenda (3) e lagoa de transbordo localizada no ponto alto da fazenda (4) 
O efluente, pouco viscoso, translúcido, porém com coloração escura, apresenta-se com teor de sódio médio em torno de 50 ppm (Tabela 8). O sódio presente origina-se da utilização de soluções de hidróxido de sódio a 1,5\% para assepsia dos equipamentos da indústria juntamente com a água extraída da laranja, durante o processo de concentração do suco, segundo Coelho ${ }^{1}$.

Tabela 8 . Teores de Na+ no efluente em Julho, Agosto e Setembro de 2003

\begin{tabular}{|c|c|c|c|c|c|}
\hline \multicolumn{2}{|c|}{ Julho } & \multicolumn{2}{|c|}{ Agosto } & \multicolumn{2}{|c|}{ Setembro } \\
\hline Dia & $m g / l$ & dia & $m g / l$ & Dia & $M g / l$ \\
\hline $4-7$ & 37,8 & 1 & 84,41 & 1 & 54,1 \\
\hline $7-8$ & 40,6 & $1-4$ & 30 & $1-21$ & 164 \\
\hline $8-10$ & 25,4 & $4-5$ & 37,8 & $2-3$ & 56 \\
\hline $10-11$ & 60,7 & $5-7$ & 29,5 & 4 & 65 \\
\hline $11-14$ & 31,2 & $7-8$ & 35,4 & 5 & 60 \\
\hline $14-15$ & 37,20 & $8-11$ & 26,9 & 6 & 45 \\
\hline $15-16$ & 30,0 & $11-12$ & 55,0 & 7 & 45 \\
\hline $16-17$ & 19,9 & $12-13$ & 44,10 & 8 & 42 \\
\hline $17-18$ & 16,9 & $13-14$ & 48,8 & 9 & 168 \\
\hline $18-21$ & 13,8 & $14-15$ & 41,8 & 10 & 63 \\
\hline $21-22$ & 52,0 & $15-18$ & - & 11 & 41 \\
\hline $22-23$ & 32,4 & $18-19$ & 89 & 12 & 43 \\
\hline $23-24$ & 22,4 & $19-20$ & 37,1 & 13 & 45 \\
\hline $24-25$ & 17,5 & $20-21$ & 37 & 14 & 54 \\
\hline $25-28$ & 16,2 & $21-22$ & 36,0 & 15 & 56 \\
\hline $28-29$ & 18,30 & $22-25$ & 35,9 & 16 & 66 \\
\hline $29-30$ & 80,0 & $25-26$ & 36,7 & 17 & 77 \\
\hline $30-31$ & 32,7 & $26-28$ & - & 18 & 121 \\
\hline
\end{tabular}

Fonte: Grupo Fischer, 2003.

\footnotetext{
${ }^{1}$ COELHO, C. (CITROSUCO, Matão). Comunicação pessoal, 2002.
} 


\subsection{Capim-de-rhodes}

Em avaliações pretéritas a este trabalho, segundo Aloisi \& $\mathrm{Mazza}^{2}$, no mesmo local, verificou-se que o Capim-de-rhodes foi mais eficiente na extração de $\mathrm{Na}$ (cerca de 80 kg.ha-1) quando comparado à Brachiaria decumbens (Tabela 9). Esta informação, aliada à alta tolerância à salinidade (Allison, 1964), sugeria o Capim-de-rhodes como uma boa opção para cultivo em áreas com aplicação do efluente, como no contexto da Fazenda Trindade.

Tabela 9 . Extração de elementos por braquiária (Brachiaria decumbens) e Capim-derhodes (Chloris gayana)

\begin{tabular}{cccccccc}
\hline $\mathbf{N}$ & $\mathbf{P}$ & $\mathbf{K}$ & $\mathbf{C a} \mathbf{M g}$ & $\mathbf{S}$ & $\mathbf{C l}$ & $\mathbf{N a}$ \\
\hline 80,4 & 22,7 & 237,1 & \multicolumn{2}{c}{$\begin{array}{c}\text { braquiária } \\
\text { capim-de-rhodes }\end{array}$} & 20,6 & 46 & 1,8 \\
94,2 & 16,9 & 125,9 & $37 \quad 14,8$ & 39,2 & 72,7 & 79,2 \\
\hline
\end{tabular}

\subsection{Caracterização do experimento com o Capim-de-rhodes}

\subsubsection{Características da área do experimento}

O capim foi inicialmente plantado em Outubro de 2002 e até a instalação do experimento haviam sido realizados em torno de cinco cortes. A situação histórica da área mostra que, apesar da aplicação contínua do efluente, o solo não perdeu sua capacidade produtiva.

${ }^{2}$ ALOISI, R. R.; MAZZA, J. A. (ESALQ / USP, Piracicaba). Comunicação pessoal, 2002. 
As parcelas localizaram-se sobre uma porção onde o capim apresentava-se homogêneo, com declividade aproximada de 5\%, sem sinais aparentes de erosão (Figura $10)$.

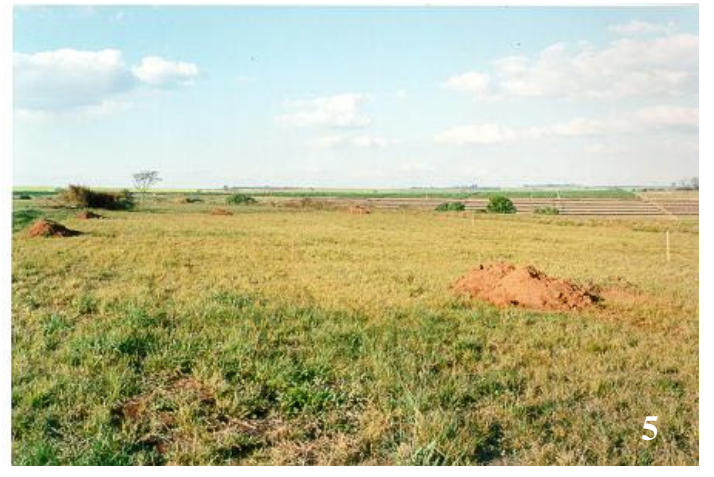

Figura 10 - Situação do campo na instalação do ensaio - massa remanescente do ciclo anterior

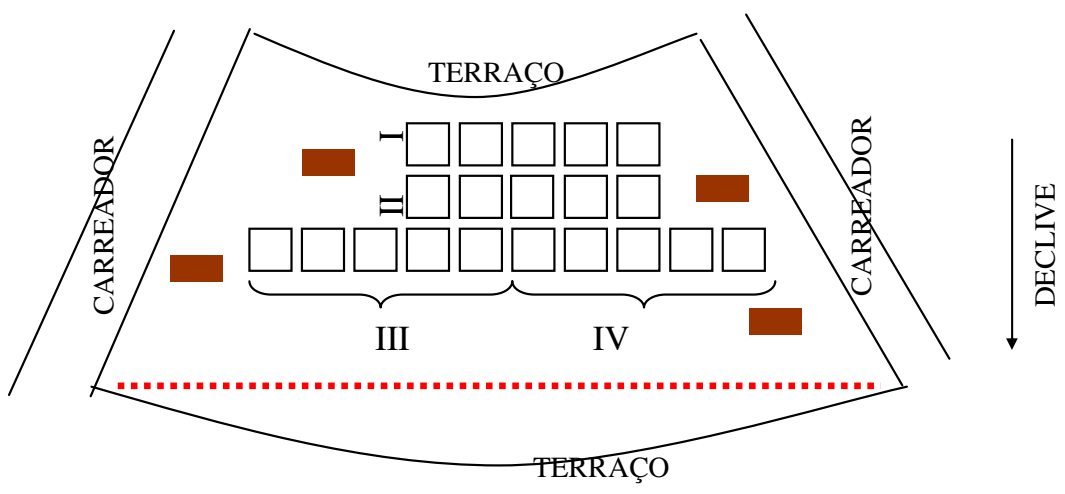

Legenda:

- parcelas

-Trincheiras

[. - - - linha de caminhamento do canhão de irrigação

I, II, III e IV - blocos.

Figura 11 - Croqui do ensaio 
As parcelas foram instaladas com $7 \mathrm{~m}$ de comprimento e $6 \mathrm{~m}$ de largura, totalizando $42 \mathrm{~m}^{2}$. Entre elas deixou-se uma faixa de caminhamento de $1 \mathrm{~m}$ de largura. Foram abertas quatro trincheiras distribuídas na área do experimento para descrição morfológica, amostragem e classificação dos perfis de solos (Figura 11). A linha tracejada representa o alinhamento no qual foi posicionado o aspersor de irrigação (tipo canhão hidráulico - Figura 12), que aplicou efluente na área do ensaio.

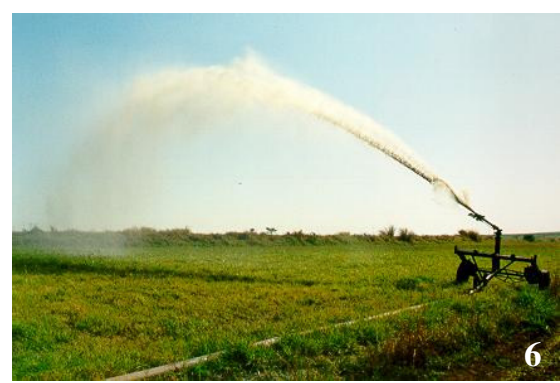

Figura 12 - Canhão de aspersão em operação com efluente industrial (6)

\subsubsection{Delineamento experimental, tratamentos e análises estatísticas}

$\mathrm{O}$ delineamento experimental adotado foi o de parcelas em blocos ao acaso com quatro repetições. A grade de tratamentos, conforme planejada (Tabela 10), teve como objetivos traçados: (1) a avaliação do sódio no solo, considerando a condição de solo nu (trat. 1) e (2) os tratamentos 2 a 5 objetivaram a avaliação do potencial de extração de sódio pelo capim em diferentes condições nutricionais.

Previamente à aplicação dos tratamentos, foram utilizados $100 \mathrm{~kg}$ de $\mathrm{P}_{2} \mathrm{O}_{5} \cdot \mathrm{ha}^{-1}$ na forma de superfosfato simples e $500 \mathrm{~kg} \cdot \mathrm{ha}^{-1}$ de calcário dolomítico, para que não fossem limitantes ao desenvolvimento do capim os nutrientes $\mathrm{P}, \mathrm{Ca}$ ou $\mathrm{Mg}$.

Como fonte de $\mathrm{N}$ foi utilizado o Nitrato de Amônio, por não apresentar perdas por volatilização e efeito acidificante. Para fornecimento de $\mathrm{K}$ foi utilizado o cloreto de potássio. Ambas as fontes eram formuladas em grãos simples. A distribuição dos 
fertilizantes foi realizada manualmente depois de pesados em balança com precisão de $1 \mathrm{~g}$.

A cada corte do capim, a quantidade de fertilizante prevista nos tratamentos foi reposta. Assim sendo, ao final do experimento os tratamentos três, quatro e cinco receberam 100, 200 e $400 \mathrm{~kg} \cdot \mathrm{ha}^{-1}$ de $\mathrm{N}$ e $\mathrm{K}_{2} \mathrm{O}$, num período de 80 dias.

As irrigações com efluente foram realizadas cinco vezes, de acordo com a disponibilidade do efluente na indústria. A Figura 13 ilustra o montante aplicado por irrigação e o total acumulado até o final do ensaio.

Utilizou-se o programa estatístico Minitab 14 para análise dos dados. Os resultados foram submetidos à análise de variância e nos casos de $\mathrm{F}$ significativo aplicou-se o teste de Tukey a $10 \%$ de probabilidade.

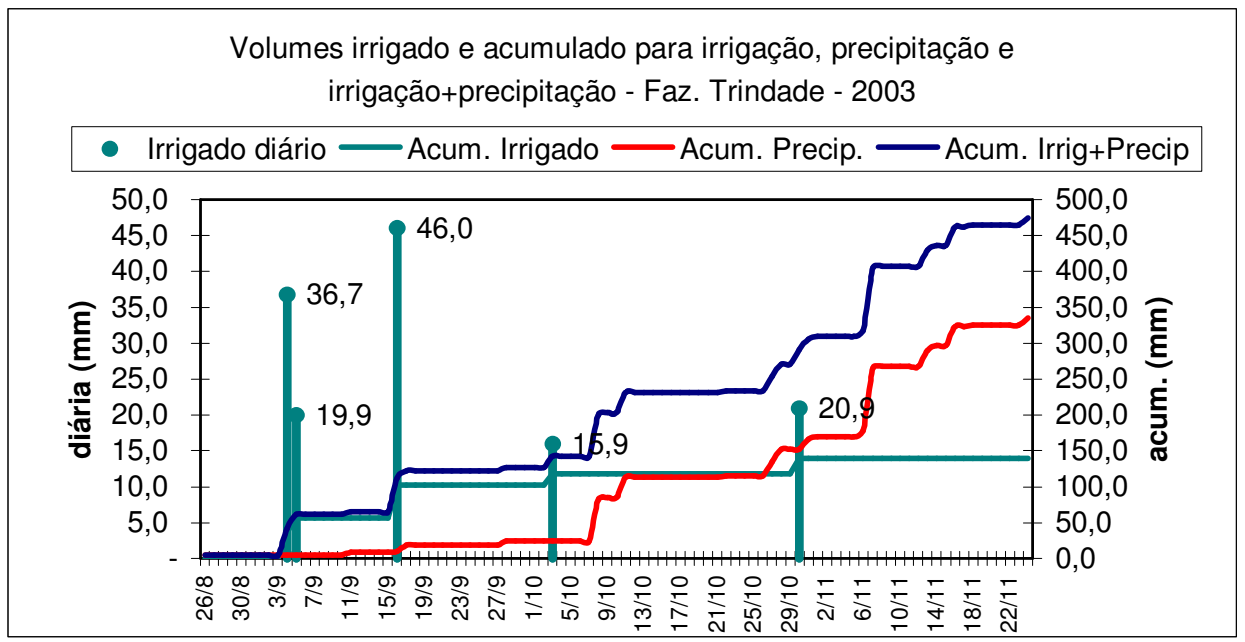

Figura 13 - Gráfico dos volumes de irrigação diária, precipitação e irrigação acumulados 
Tabela 10 . Grade de tratamentos do experimento com Capim-de-rhodes

\begin{tabular}{cccc}
\hline Tratamento & Vegetação & $\begin{array}{c}\text { Dose de Nitrogênio } \\
\mathrm{Kg} \mathrm{N} \mathrm{ha}^{-1} \cdot \text { corte }^{-1}\end{array}$ & $\begin{array}{c}\text { Dose de Potássio } \\
\mathrm{Kg} \mathrm{K}_{2} \mathrm{O}_{\text {ha }}{ }^{-1} \cdot \text { corte }^{-1}\end{array}$ \\
\hline 1 & Ausente & 0 & 0 \\
2 & Rhodes & 0 & 0 \\
3 & Rhodes & 50 & 50 \\
4 & Rhodes & 100 & 100 \\
5 & Rhodes & 200 & 200 \\
\hline
\end{tabular}

\subsection{Avaliações}

\subsubsection{Capim}

Foram realizados três cortes de capim para cálculo da produção de massa e análise foliar para macronutrientes. O primeiro, em 26 de agosto, teve o objetivo de avaliar o remanescente de massa no período pré-experimental. O segundo realizou-se em 13 de outubro, 40 dias após a primeira aplicação dos fertilizantes, e o terceiro em 24 de novembro, ou seja, 40 dias após a segunda aplicação. Quadros metálicos com $0,25 \mathrm{~m}^{2}$ foram empregados para demarcação da área a ser colhida (Figura 14), sendo que se retirou três sub-amostras por parcela, totalizando $0,75 \mathrm{~m}^{2}$ de área colhida por parcela. Após cada coleta, todo o campo era roçado e todo o capim retirado, de forma a simular a exportação de nutrientes em área total, como ocorreria na produção de feno (Figura 4, foto 2).

Após os cortes, todo o material foi seco em estufa com circulação forçada de ar a $60^{\circ} \mathrm{C}$ até atingir massa constante. Em seguida efetuou-se a pesagem de todo o material para determinação da produção de massa seca do capim.

As análises do tecido vegetal foram realizadas no Laboratório de Plantas do Departamento de Solos e Nutrição de Plantas da ESALQ-USP. Para o preparo dos 
extratos fez-se digestão sulfúrica para a determinação do nitrogênio, digestão nítricoperclórica para a determinação do fósforo, potássio, cálcio, magnésio, enxofre. A determinação do nitrogênio foi através do método Micro Kjeldahl. O fósforo foi determinado por colorimetria do metavanadato, o potássio por fotometria de chama de emissão, o cálcio e o magnésio por espectrofotometria de absorção atômica. A determinação do enxofre foi por turbidimetria do sulfato de bário (Sarruge \& Haag, 1974, Bataglia et al., 1983).

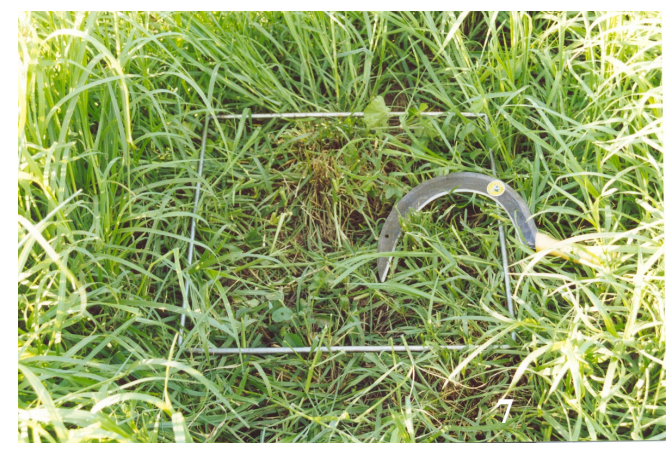

Figura 14 - Ancinho para corte e quadro com $0,25 \mathrm{~m}^{2}$ para amostragem do capim

\subsubsection{Solo e efluente}

Foi possível também monitorar as variações dos teores de $\mathrm{Na}$ no solo através de amostragens de terra antes da primeira aplicação de efluente e fertilizantes, em 26 de Agosto, e a cada corte do capim.

As amostras foram retiradas em cada parcela, sendo cinco sub-amostras em três profundidades: 0-15, 15-30 e 30-50 cm.

As análises de solo em laboratório seguiram as metodologias descritas para rotina em determinação da fertilidade do solo (Raij et al, 2001): pH (água e $\mathrm{CaCl}_{2}$ ), $\mathrm{MO}, \mathrm{P}, \mathrm{K}, \mathrm{Ca}$, $\mathrm{Mg}, \mathrm{Al}, \mathrm{H}+\mathrm{Al}, \mathrm{SB}, \mathrm{CTC}, \mathrm{V} \%$ e M\%. Para a extração de $\mathrm{Na}$, utilizou-se a solução Mehlich-1 ( $\mathrm{HCl} 0,05$ mol. $\mathrm{l}^{-1}+\mathrm{H}_{2} \mathrm{SO}_{4}$ 0,0125 mol. $\left.{ }^{-1}\right)$ na relação solo:solução de 1:10 (v:v). A determinação das concentrações foi realizada por meio do método instrumental Fotometria de Emissão em Chama. 
O efluente aplicado foi coletado em cada evento de irrigação através de recipientes dispostos aleatoriamente na área do ensaio. Cada amostra foi analisada quanto aos teores totais em $\mathrm{Ca}, \mathrm{Mg}, \mathrm{K}$ (Espectrofotometria de Absorção Atômica), sódio (Espectrofotometria de Chama) e bicarbonatos (titulação acidimétrica), bem como os valores de condutividade elétrica (CE), sólidos totais dissolvidos (STD) e pH.

A quantidade de sódio aplicada por irrigação pôde ser calculada através da informação da concentração de $\mathrm{Na}$ no efluente multiplicado pelo volume irrigado. Este último, medido através de 10 pluviômetros instalados na área (Figura 15)

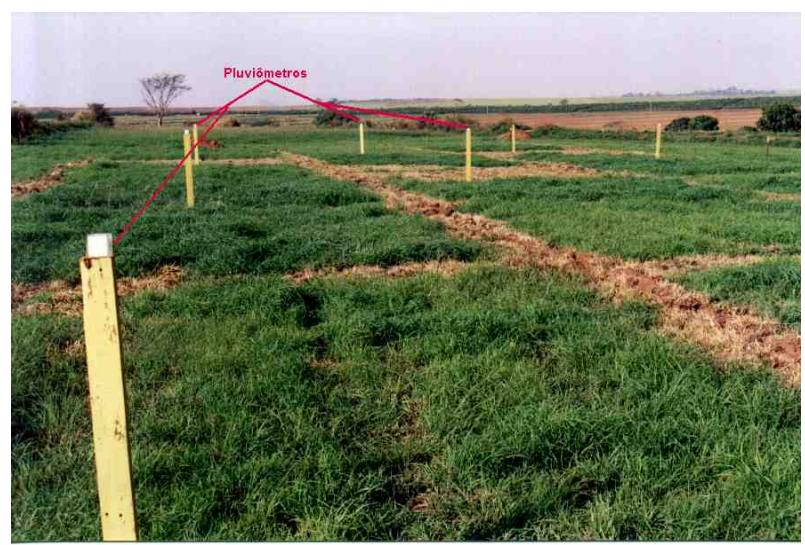

Figura 15 - Localização dos pluviômetros, sobre estacas a 1,5 m do solo 


\section{RESULTADOS E DISCUSSÃO}

\subsection{Análises do efluente}

Os resultados das análises do efluente coletado durante as irrigações (Tabela 11), confirmaram os dados fornecidos pela Citrosuco (Tabela 8) quanto ao teor de sódio, apresentando em média $53 \mathrm{mg} . \mathrm{l}^{-1}$. Em nenhuma das datas de coleta o efluente do experimento superou os teores médios encontrados em efluentes domésticos ou industriais, descritos por Feigin et al (1991), situados entre 100 e $800 \mathrm{mg} . \mathrm{l}^{-1}$. O efluente apresentou-se com teores consideráveis de Ca e K com médias de 44,6 e 31,1 mg.l', respectivamente. Algum conteúdo em nitrogênio mineral e Mg também ocorreu, com média de $12 \mathrm{mg} . \mathrm{l}^{-1}$ e $5,11 \mathrm{mg} . \mathrm{l}^{-1}$, respectivamente.

Quanto ao $\mathrm{pH}$, obtiveram-se valores perto da neutralidade, com média de 6,84. Este valor favorece a qualidade da água, evitando a precipitação do $\mathrm{Ca}$ sob a forma de $\mathrm{CaCO}_{3}$, que ocorreria com pH acima de 7,5, segundo Bower \& Chaney (1974). A presença do $\mathrm{Ca}$ sob a forma insolúvel (carga zero) não permitiria a compensação do efeito dispersante do $\mathrm{Na}$, pois não poderia se ligar às cargas negativas dos colóides.

Para o calculo da RAS, os teores de $\mathrm{Ca}, \mathrm{Mg}$ e Na foram transformados em mmol $_{\mathrm{c}} \mathrm{I}^{-1}$, a fim de se utilizar a fórmula descrita no item 2.2.1. $\mathrm{O}$ alto teor de $\mathrm{Ca}$, relativamente ao de $\mathrm{Na}$, favoreceu para que a RAS fosse baixa em todas as amostras de efluente, ficando a média em 1,97. Nestes valores há menor risco de dispersão de argilas no solo e, portanto, pouca ou nenhuma interferência na permeabilidade e aeração, segundo Paganini (1997). Ainda, segundo a tabela de interpretação da qualidade de águas de irrigação da FAO (Ayers \& Westcot, 1985 - Tabela 3), o efluente do ensaio seria 
classificado como de salinidade moderada, e de nenhuma restrição quanto ao risco de redução da taxa de infiltração de água no solo ou toxicidade específica de $\mathrm{Na}$. Entretanto, segundo a EPA - Austrália, que considera somente a salinidade da água, Tabela 2, o efluente estaria classificado ora como classe 2 (salinidade média), ora como classe 3 (salinidade alta).

A classe 3 define-se como: as águas mais próximas do limite superior deste grupo não podem ser utilizadas em áreas que apresentem restrições quanto à drenagem, e rigor específico deve ser aplicado na definição da espécie vegetal a ser irrigada. Considerando-se que a análise morfológica do solo do experimento não evidenciou nenhum problema de drenagem e que o efluente esteve sempre perto do limite inferior da classe 3, aliado à tolerância do Capim-de-rhodes à salinidade, conclui-se que o efluente em questão não deve oferecer risco ao sistema produtivo. A classe 2 menciona que o uso de águas desta classe está condicionado à ocorrência de lixiviação. Observando o balanço hídrico para a região de Matão (Figura 7), nota-se o excesso hídrico entre os meses de novembro a abril, favorecendo a lixiviação e, portanto, justificando a irrigação com efluente de classe 2.

Cabe ainda mencionar que os critérios da FAO e da EPA Austrália são criados para áreas onde a irrigação é fundamental para o desenvolvimento agrícola, em regiões de precipitação pequena, em climas semi-áridos. Haveria de se desenvolver critérios específicos de avaliação da qualidade de águas residuárias envolvendo a sua utilização nas situações de clima tropical úmido, onde se soma ao efluente um significativo excedente hídrico em pelo menos um terço à metade de um ano.

Levando-se em conta as recomendações de Paganini (1997), analisou-se o teor de bicarbonatos no efluente a fim de se obter a Adj.RAS e, desta forma, verificar se haveria prejuízos à qualidade do efluente devido à sua alcalinidade. A Adj. RAS foi então calculada considerando-se a equação descrita também no item 2.2.1, que leva em conta o teor de bicarbonato do efluente para obtenção do valor de $\mathrm{Ca}_{\mathrm{x}}$ (Tabela 1). O incremento do valor da RAS para Adj.RAS (média 3,04) não foi suficiente para alterar a interpretação e classificação do efluente segundo os critérios acima mencionados. 
Durante a condução do ensaio, foram realizadas 5 irrigações. A Tabela 12 sintetiza as informações da quantidade de efluente irrigado e precipitação média (coletada nos dez pluviômetros instalados na área), o teor de elementos do efluente e finalmente a quantidade aplicada dos mesmos sobre as parcelas.

As quantidades de nutrientes ( $\mathrm{K}, \mathrm{Ca}, \mathrm{Mg}$ e $\mathrm{N}$ ) aplicadas corroboram com as hipóteses de Hespanhol (2002), Oron (1996) e Meli et al (2002), onde o uso de águas residuárias na agricultura faz-se interessante, pelo aporte de nutrientes que podem ocorrer, reduzindo eventualmente a necessidade de complementação com fertilizantes minerais.

Tabela 11 . Análise do efluente coletado durante as irrigações do experimento

\begin{tabular}{|c|c|c|c|c|c|c|c|}
\hline \multirow[t]{2}{*}{ Parâmetro } & \multirow[t]{2}{*}{ Unidade } & \multicolumn{6}{|c|}{ Data da amostragem } \\
\hline & & 04 e 05/09 & $\begin{array}{c}\text { 16/09 } \\
\text { manhã }\end{array}$ & $\begin{array}{l}16 / 09 \\
\text { tarde }\end{array}$ & 03/out & $30 /$ out & Média \\
\hline $\mathrm{N}$ total & $\mathrm{mg} / \mathrm{l}$ & 81,38 & 53,76 & 83,33 & 66,66 & 77,41 & 72,51 \\
\hline $\mathrm{NH} 4$ & $\mathrm{mg} / \mathrm{l}$ & 15,19 & 6,12 & 13,57 & 12,77 & 12,23 & 11,98 \\
\hline NO3 & $\mathrm{mg} / \mathrm{l}$ & 0,10 & 0,10 & 0,10 & 0,10 & 0,10 & 0,10 \\
\hline NO2 & $\mathrm{mg} / \mathrm{l}$ & 0,01 & 0,01 & 0,01 & 0,01 & 0,01 & 0,01 \\
\hline Bicarbonatos & $\mathrm{mg} / \mathrm{l}$ & 756 & 692 & 752 & 741 & 742 & 736,60 \\
\hline Cálcio & $\mathrm{mg} / \mathrm{l}$ & 46,5 & 43,7 & 46,4 & 47,4 & 39 & 44,60 \\
\hline Magnésio & $\mathrm{mg} / \mathrm{l}$ & 6,65 & 4,25 & 5,72 & 6,62 & 2,31 & 5,11 \\
\hline Potássio & $\mathrm{mg} / \mathrm{l}$ & 50,6 & 24,6 & 23,7 & 41,8 & 14,8 & 31,10 \\
\hline Sódio & $\mathrm{mg} / \mathrm{l}$ & 58,5 & 51,1 & 49 & 74,8 & 30,2 & 52,72 \\
\hline $\mathrm{HCO} / \mathrm{Ca}$ & - & 5,33 & 5,19 & 5,31 & 5,13 & 6,24 & 5,44 \\
\hline Cax & - & 0,74 & 0,71 & 0,71 & 0,74 & 0,55 & 0,69 \\
\hline $\mathrm{PH}$ & - & 6,72 & 6,83 & 6,94 & 7,07 & 6,65 & 6,84 \\
\hline CE & $\mathrm{dS} / \mathrm{m}$ & 1,38 & 0,962 & 0,985 & 1,309 & 0,665 & 1,06 \\
\hline STD & $\mathrm{mg} / \mathrm{l}$ & 883,2 & 615,68 & 630,4 & 837,76 & 425,6 & 678,53 \\
\hline RAS & - & 2,12 & 1,97 & 1,80 & 2,69 & 1,27 & 1,97 \\
\hline RAS Ajustada & - & 3,16 & 3,05 & 2,77 & 4,05 & 2,15 & 3,04 \\
\hline
\end{tabular}


Tabela 12 . Irrigação com o efluente aplicado no experimento, teor de elementos e quantidade resultante aplicada ao solo

\begin{tabular}{|c|c|c|c|c|c|c|c|c|c|c|c|}
\hline \multirow[b]{2}{*}{ Data } & \multirow{2}{*}{$\begin{array}{c}\text { Precip. } \\
\text { mm }\end{array}$} & \multicolumn{5}{|c|}{ Teor do elmenento (mg.l-1) } & \multicolumn{5}{|c|}{ Quantidade Aplicada (kg.ha-1) } \\
\hline & & $\mathrm{Na}$ & $\mathrm{K}$ & $\mathrm{Ca}$ & $\mathrm{Mg}$ & $\mathrm{N}$ & $\mathrm{Na}$ & $\mathrm{K}$ & $\mathrm{Ca}$ & $\mathrm{Mg}$ & $\mathrm{N}$ \\
\hline $4 / 9$ & 36,7 & 58,5 & 50,6 & 46,5 & 6,65 & 15,29 & 21,5 & 18,6 & 17,1 & 2,4 & 5,6 \\
\hline $5 / 9$ & 19,9 & 58,5 & 50,6 & 46,5 & 6,65 & 15,29 & 11,6 & 18,6 & 17,1 & 2,4 & 5,6 \\
\hline 16/9-manhã & 24,5 & 51,1 & 24,6 & 43,7 & 4,25 & 6,22 & 12,5 & 9,0 & 16,0 & 1,6 & 2,3 \\
\hline 16/9-tarde & 21,5 & 49,0 & 23,7 & 46,4 & 5,72 & 13,67 & 10,5 & 8,7 & 17,0 & 2,1 & 5,0 \\
\hline $3 / 10$ & 15,9 & 74,8 & 41,8 & 47,4 & 6,62 & 12,87 & 11,9 & 15,3 & 17,4 & 2,4 & 4,7 \\
\hline $30 / 10$ & 20,9 & 30,2 & 14,8 & 39,0 & 2,31 & 12,33 & 6,3 & 5,4 & 14,3 & 0,8 & 4,5 \\
\hline Média & 23,2 & 53,7 & 34,4 & 44,9 & 5,4 & 12,6 & 12,4 & 12,6 & 16,5 & 2,0 & 4,6 \\
\hline Total & 139,3 & - & - & - & - & - & 74,3 & 75,6 & 98,9 & 11,8 & 27,8 \\
\hline
\end{tabular}

\subsection{Produção de massa do Capim-de-rhodes}

Os dados do remanescente de massa do capim, resultante do período seco de 2003 (Tabela 13), foram levantados coletando-se três sub-amostras por bloco, antes da instalação do experimento, dois meses após o último corte comercial realizado nas operações convencionais da fazenda. A época, caracterizada por um forte déficit hídrico, juntamente com a falta de fertilização mineral, justificou os baixos valores de produção de MS.

Do ponto de vista experimental, as condições hídricas e nutricionais deficientes do capim, antes do ensaio, foram favoráveis para evidenciar qualquer resposta aos tratamentos e à irrigação com o efluente. A Figura 10 ilustra claramente a situação do campo antes das irrigações e fertilizações. 
Tabela 13 . Determinação da matéria seca remanescente antes da aplicação dos tratamentos.

\begin{tabular}{cc}
\hline Bloco & $\begin{array}{c}\text { MS } \\
\text { t.ha }\end{array}$ \\
\hline I & 0,97 \\
II & 1,10 \\
III & 0,74 \\
IV & 0,63 \\
média & 0,86 \\
\hline
\end{tabular}

Como o solo apresentava-se bem em termos de fertilidade (Tabela 6), sem limitações em termos de pH, soma de bases, saturação por bases, fósforo, etc, o capim apresentou desenvolvimento diferenciado, imediatamente após as primeiras irrigações, nos diferentes tratamentos com ou sem aplicação dos fertilizantes minerais (Figura 16, Figura 17 e Figura 18).

Vinte dias após a instalação do ensaio, o desenvolvimento do capim nas parcelas com as maiores doses foi visualmente superior àquele das parcelas com $50 \mathrm{~kg} \cdot \mathrm{ha}^{-1}$ de $\mathrm{N}$ e $\mathrm{K}_{2} \mathrm{O}$ ou sem fertilizante. Já não eram tão evidentes as diferenças entre 100 e 200 kg.ha ${ }^{-1}$ de $\mathrm{N}$ e $\mathrm{K}_{2} \mathrm{O}$.

A Tabela 14 contém os dados de produção de matéria seca nas três datas de colheita do capim.

Analisando-se inicialmente os dados do tratamento sem fertilizante, observa-se em 13 de outubro produção pelo menos duas vezes maior quando comparada com a situação em 26 de agosto. Nota-se, ainda, um aumento de quase duas vezes comparando-se o último corte, em 24 de novembro, com o segundo. Pode-se dizer que esta resposta provavelmente não se deve somente à fertilidade do solo e à ocorrência das chuvas, mas também ao aporte de nutrientes pelo efluente, conforme observa-se na Tabela 12. O desenho experimental adotado não permite concluir sobre o assunto, pois seria necessário um tratamento irrigado somente com água, o que motiva novas hipóteses a serem abordadas em estudos futuros, já colocadas por Hespanhol (2002), Oron (1996) e Meli et al (2002). 
Pelos dados apresentados para o tratamento sem fertilizante já se pode concluir que a produção está condicionada preliminarmente à época de colheita. Os tratamentos com fertilizante tiveram acréscimos ainda maiores de uma época para outra.

A comparação entre as médias mostra que em 13 de outubro houve diferença significativa entre o tratamento com a maior dose e aqueles com a menor dose, ou sem fertilizante. $\mathrm{O}$ tratamento de $100 \mathrm{~kg}$ de $\mathrm{N} \mathrm{e} \mathrm{K}_{2} \mathrm{O} \mathrm{ha}^{-1}$ também difere estatisticamente do tratamento sem fertilizante. Embora não haja diferença estatística entre todos os tratamentos, a situação no campo era visualmente evidente, conforme demonstra a Figura 20.

Em 24 de novembro, os tratamentos não diferiram entre si, exceto pelo tratamento da maior dose que diferiu daquele sem fertilizante. Nesta data, porém, foram encontradas as maiores diferenças entre os tratamentos com fertilizante e a testemunha. A mudança no regime pluviométrico após o primeiro corte (Figura 8 e Figura 13) permitiu provavelmente melhor aproveitamento dos nutrientes do efluente e dos tratamentos de menor dose, devido à maior disponibilidade de água. No período de 13 de outubro a 24 de novembro considera-se também que o sistema radicular, tipicamente vigoroso nas gramíneas, tenha se desenvolvido intensamente, contribuindo também para aumento do rendimento agrícola.

O gráfico da Figura 19 retrata a análise fatorial (data e tratamento) realizada para os dados de produção de massa. A análise de variância ao nível de 10\% de probabilidade resultou em resposta significativa para tratamentos $(\mathrm{F}=7,14$ e $\mathrm{p}=0,001)$ e para data de colheita $(\mathrm{F}=50,99$ e $\mathrm{p}=0,000)$, mas não foi significativa para a interação dos fatores $(\mathrm{F}=0,49$ e $\mathrm{p}=0,696)$. $\mathrm{O}$ gráfico também permite visualizar as diferenças relativas entre as médias. 
Tabela 14 . Produção de Capim-de-rhodes inicial e em 2 cortes mediante doses de fertilizantes com a aplicação de efluente

\begin{tabular}{cccc}
\hline \multirow{2}{*}{$\begin{array}{c}\text { Tratamento } \\
\left(\mathrm{kg} \mathrm{N} \mathrm{K} \mathrm{O} \mathrm{ha}^{-1}\right)\end{array}$} & 26/Agosto & 13/Outubro & 24/Novembro \\
\hline 0 & 0,86 & $1,83 \mathrm{c}$ & $3,35 \mathrm{~b}$ \\
50 & - & $2,38 \mathrm{bc}$ & $4,68 \mathrm{ab}$ \\
100 & - & $2,85 \mathrm{ab}$ & $4,78 \mathrm{ab}$ \\
200 & - & $3,40 \mathrm{a}$ & $4,99 \mathrm{a}$ \\
\hline
\end{tabular}

Médias seguidas da mesma letra não diferem entre si pelo teste de Tukey a 10\% de probabilidade.

O ganho de produção do tratamento sem fertilizante para o tratamento com 50, 100 e $200 \mathrm{~kg} \cdot \mathrm{ha}^{-1}$ de $\mathrm{N}$ e $\mathrm{K}_{2} \mathrm{O}$ é de 40,44 e $49 \%$, respectivamente. Este fato é evidentemente muito importante, pois favorece a hipótese de que o manejo da adubação adequado conduz ao rendimento agrícola elevado e, portanto, aumenta a exportação de $\mathrm{Na}$ em termos absolutos. $\mathrm{O}$ aumento de rendimento também justifica o investimento na adubação. 

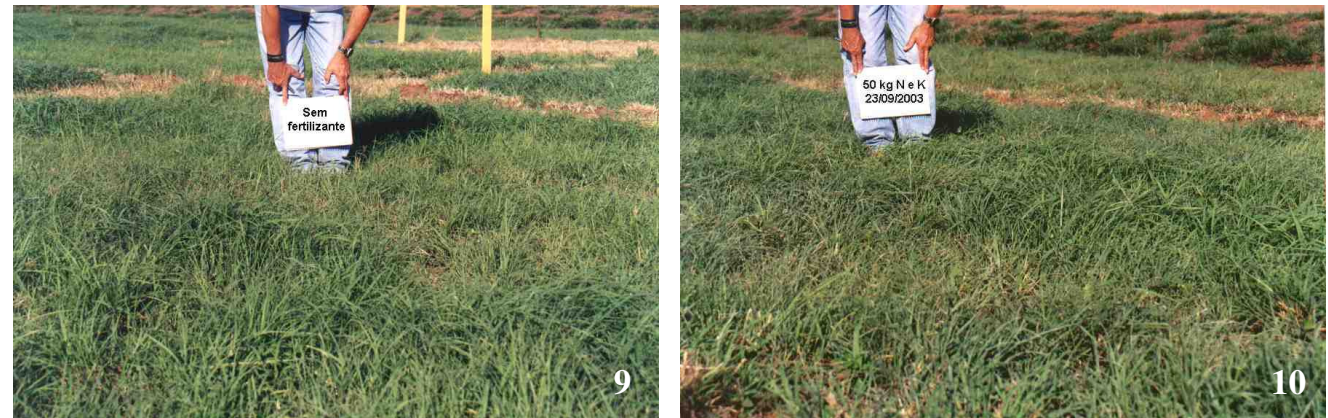

Figura 16 - Desenvolvimento do Capim-de-rhodes sem fertilizantes (9) e com 50 kg.ha ${ }^{-1}$ de $\mathrm{N}$ e $\mathrm{K}_{2} \mathrm{O}(10)$ aos 20 daa

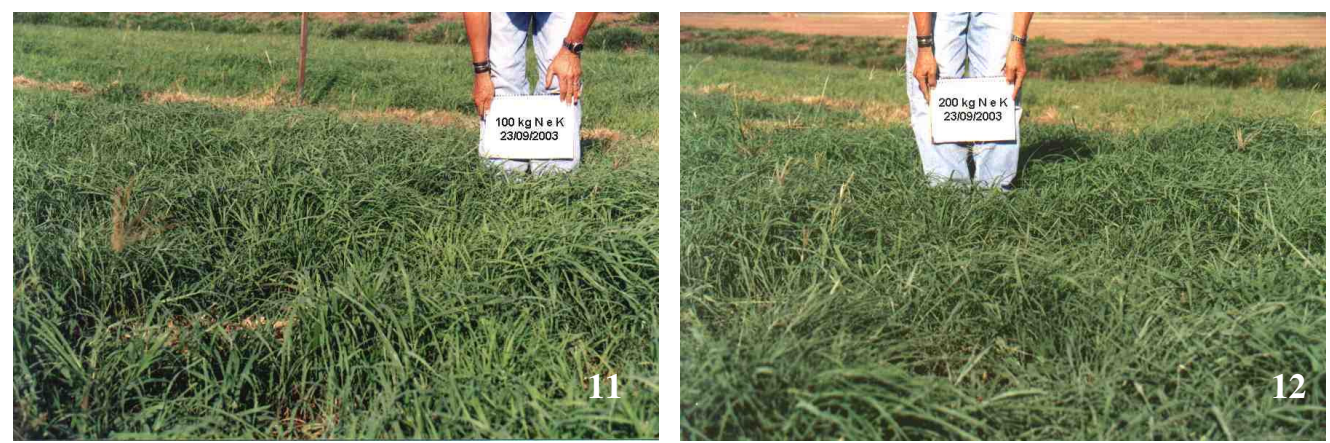

Figura 17 - Desenvolvimento do capim com 100 (11) e com 200 kg.ha ${ }^{-1}$ de $\mathrm{N}_{\text {e }} \mathrm{K}_{2} \mathrm{O}$ (12)

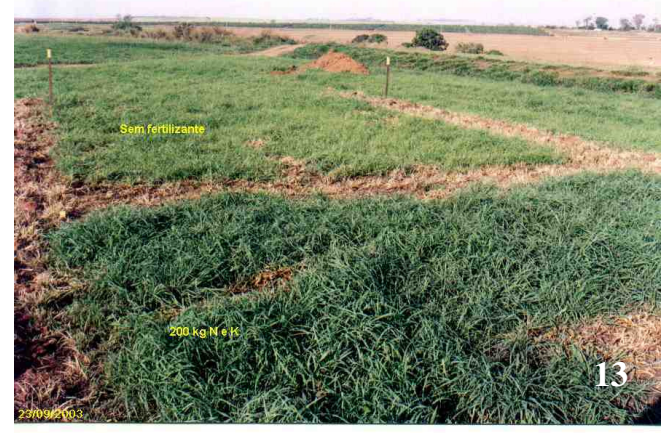

Figura 18 - Comparativo visual do desenvolvimento do capim sem fertilizante e com $200 \mathrm{~kg} \cdot \mathrm{ha}^{-1}$ de $\mathrm{N}$ e $\mathrm{K}_{2} \mathrm{O}$ 


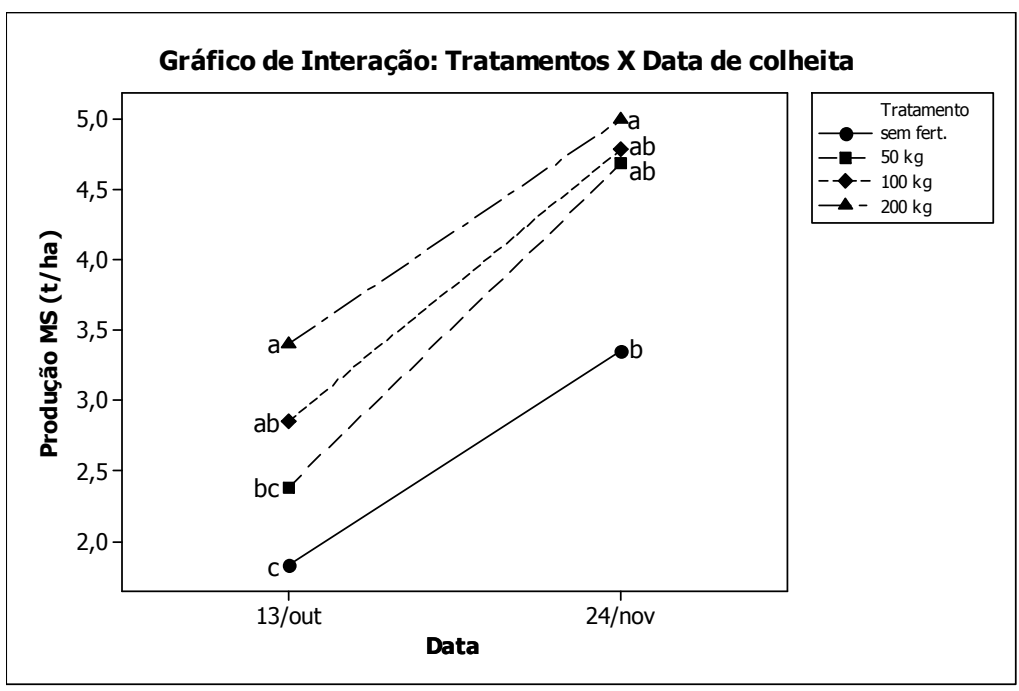

Figura 19 - Comparativo da produção do capim nas duas datas de colheita após a aplicação dos fertilizantes

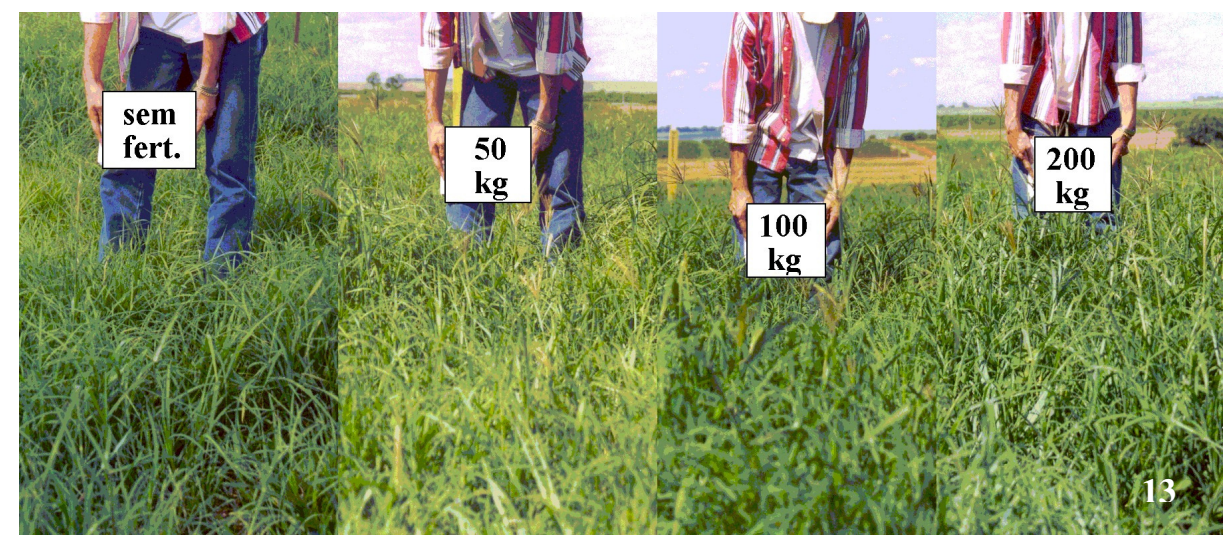

Figura 20 - Comparação do desenvolvimento do capim, imediatamente antes da colheita em 13 de outubro 


\subsection{Análises foliares e exportação de $\mathrm{Na}, \mathrm{K}, \mathrm{Ca}, \mathrm{Mg}$ e N}

Além da resposta do capim em termos de produção de massa seca, os dados obtidos a partir da análise foliar permitiram observar mudanças nos aspectos nutricionais do capim.

A análise estatística dos dados do teor foliar em Na mostram um enriquecimento no elemento em função dos tratamentos (Figura 21). Em 13 de outubro, os teores foliares dos tratamentos com 100 e $200 \mathrm{~kg}$ de $\mathrm{N} \mathrm{e} \mathrm{K}_{2} \mathrm{O} \cdot \mathrm{ha}^{-1}$ foram estatisticamente semelhantes, com aproximadamente 13 g.kg ${ }^{-1}$, superiores aos teores dos tratamentos com 0 e $50 \mathrm{~kg}$ de $\mathrm{N}$ e $\mathrm{K}_{2} \mathrm{O} \mathrm{ha}^{-1}$. Outro fato relevante que se observou foi a diferença do teor foliar das amostras de 26 de agosto para aqueles de 13 de outubro e 24 de novembro, sem fertilizante. Provavelmente o maior desenvolvimento radicular, o $\mathrm{N}$ do efluente e a maior disponibilidade de água contribuíram para tal resposta. Em 24 de novembro, o tratamento de $50 \mathrm{~kg}$ de $\mathrm{N}$ e $\mathrm{K}_{2} \mathrm{O} . \mathrm{ha}^{-1}$ distingue-se daquele sem fertilizante; entretanto, foi o tratamento com $100 \mathrm{~kg}$ que se destacou dos demais, chegando a 17,4 g. $\mathrm{kg}^{-1}$. O melhor desempenho do tratamento de menor dose ocorre coincidentemente com a melhoria do balanço hídrico, conforme já discutido no item 4.2. Esta resposta, diferenciada para as distintas épocas, pode ser comprovada pela interação entre os fatores, data e tratamento, conforme se evidencia através da Figura 22.

$\mathrm{O}$ teor foliar de K não respondeu aos tratamentos em 13 de outubro e em 24 de novembro, ocorrendo apenas variação, comparando com a situação de 26 de agosto quando o teor era de apenas $5 \mathrm{~g} \cdot \mathrm{kg}^{-1}$ (Figura 23). A manutenção dos teores estáveis nas duas colheitas após o início do ensaio se justifica porque o teor no tratamento sem fertilizante já era bastante elevado. Malavolta (1997), avaliando três espécies de gramíneas forrageiras, menciona como adequados teores entre 10 e $18{\mathrm{~g} . \mathrm{kg}^{-1}}^{-1}$, valores estes ainda inferiores aos encontrados para o Capim-de-rhodes neste trabalho. Provavelmente, o estoque de K no solo, aliado à quantidade colocada pelo efluente, foi suficiente para exceder as necessidades do capim deste nutriente. Portanto, os resultados demonstram que o Capim-de-rhodes apresentaria as mesmas respostas em termos de produção de massa se apenas o fertilizante nitrogenado tivesse sido aplicado. 
Analisando-se os dados para teores foliares em N, as respostas foram significativas (Figura 26). De maneira geral, quanto maior a dose do fertilizante nitrogenado, maior foi o teor foliar de N. A resposta foi mais consistente em 24 de novembro, com coeficiente de variação de $17 \%$, considerado médio segundo Gomes (1963). Os dados observados para o $\mathrm{N}$ conduzem à conclusão de que, ao contrário do K, a planta consumiu nitrogênio na medida em que foi fornecido.

Assim como para K, não houve resposta significativa para Ca (Figura 24), Mg (Figura 25) e P (Figura 27). O enxofre se comportou de maneira semelhante ao N (Figura 28), inclusive com a acentuação das diferenças entre os tratamentos, em 24 de novembro. Barber (1966), citado por Malavolta (1997), menciona os três processos que determinam a absorção de nutrientes pelas raízes: interceptação radicular, fluxo de massa e difusão. Cada nutriente seria absorvido preferencialmente por um dos processos e eventualmente também por uma combinação dos três com participação relativa variável. O mesmo autor, em trabalho realizado com milho, encontrou que $\mathrm{N}, \mathrm{S}$ e Na são absorvidos por fluxo de massa. Quanto ao $\mathrm{Ca}$ e $\mathrm{Mg}$, por uma combinação entre fluxo de massa e interceptação radicular, enquanto que $\mathrm{K}$ e $\mathrm{P}$ dependem mais do processo de difusão.

Estas informações ajudam a entender porque o $\mathrm{Na}, \mathrm{N}$ e $\mathrm{S}$ foram mais absorvidos à medida que as chuvas ficavam mais abundantes (de 13 de outubro para 24 de novembro). O N e S estão presentes no solo preferencialmente na forma de ânions e se movimentam facilmente, repelidos pelos colóides, explicando a semelhança de comportamento dos dados entre estes dois macronutrientes. O Na também é altamente móvel no solo, devido a seu raio hidratado elevado, e, portanto, adsorvido com pequena atração aos colóides (Tan, 1993). 


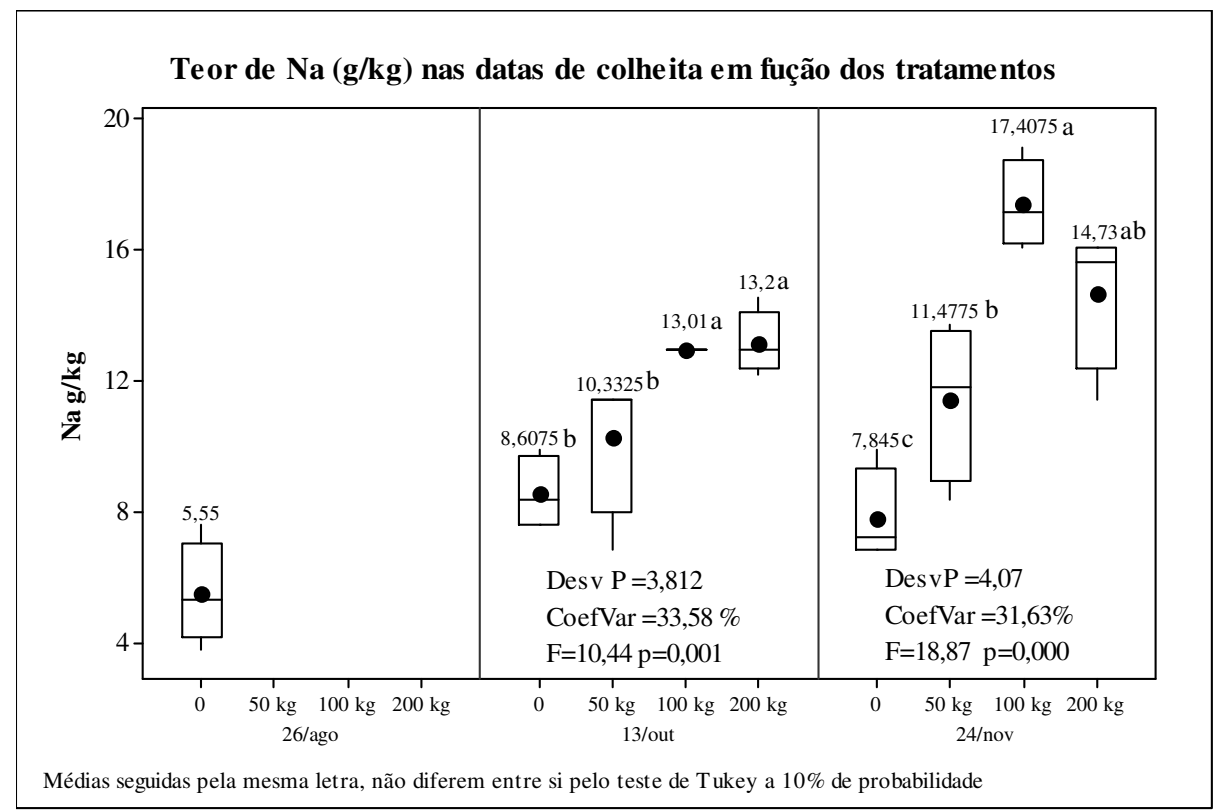

Figura 21 - Evolução dos teores foliares de $\mathrm{Na}$ em função dos tratamentos e datas

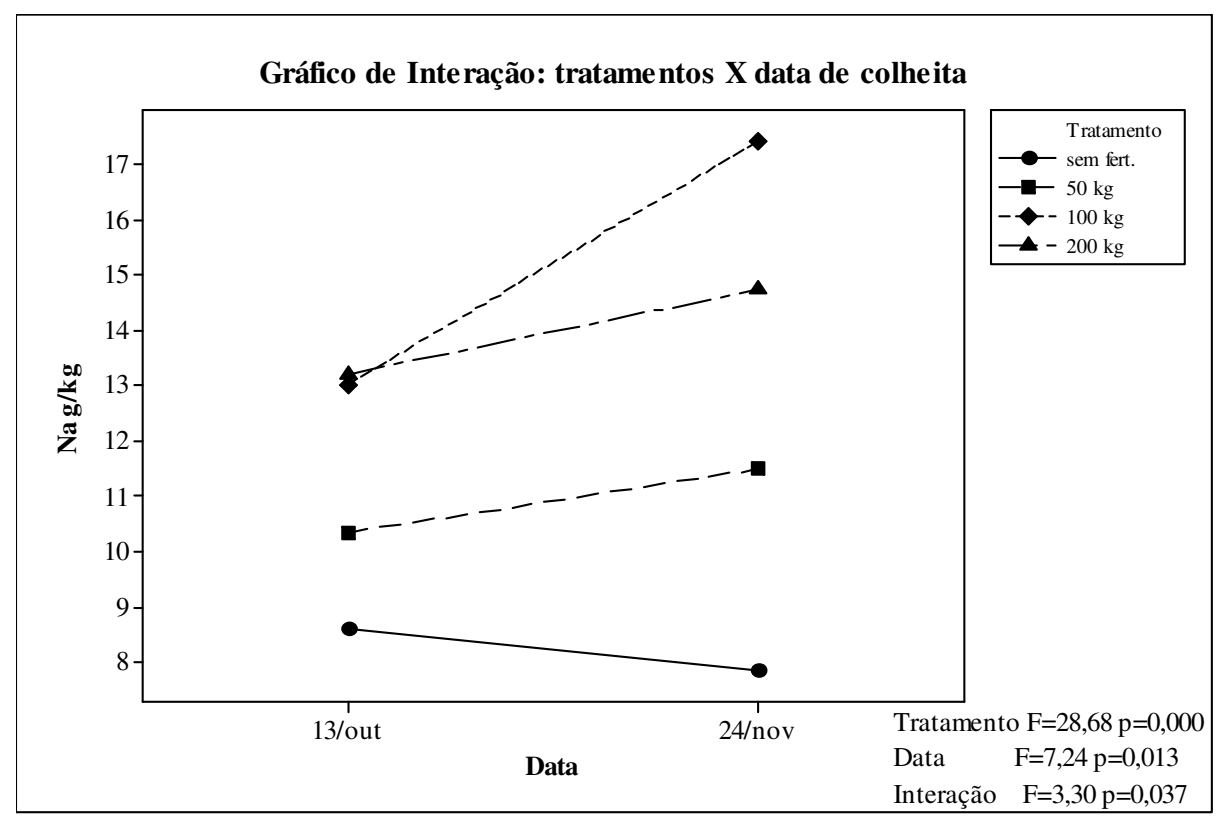

Figura 22 - Interação dos fatores data e tratamento para teor foliar em Na 


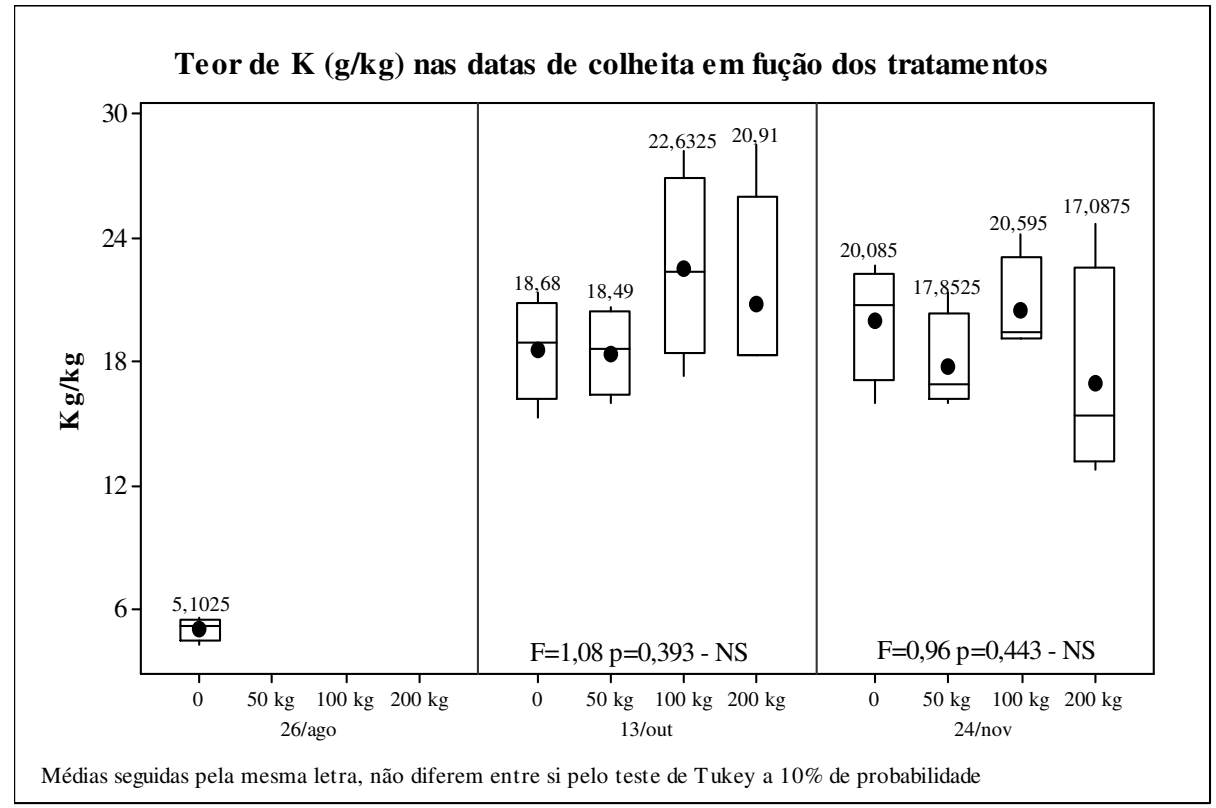

Figura 23 - Evolução dos teores foliares de K em função dos tratamentos e datas

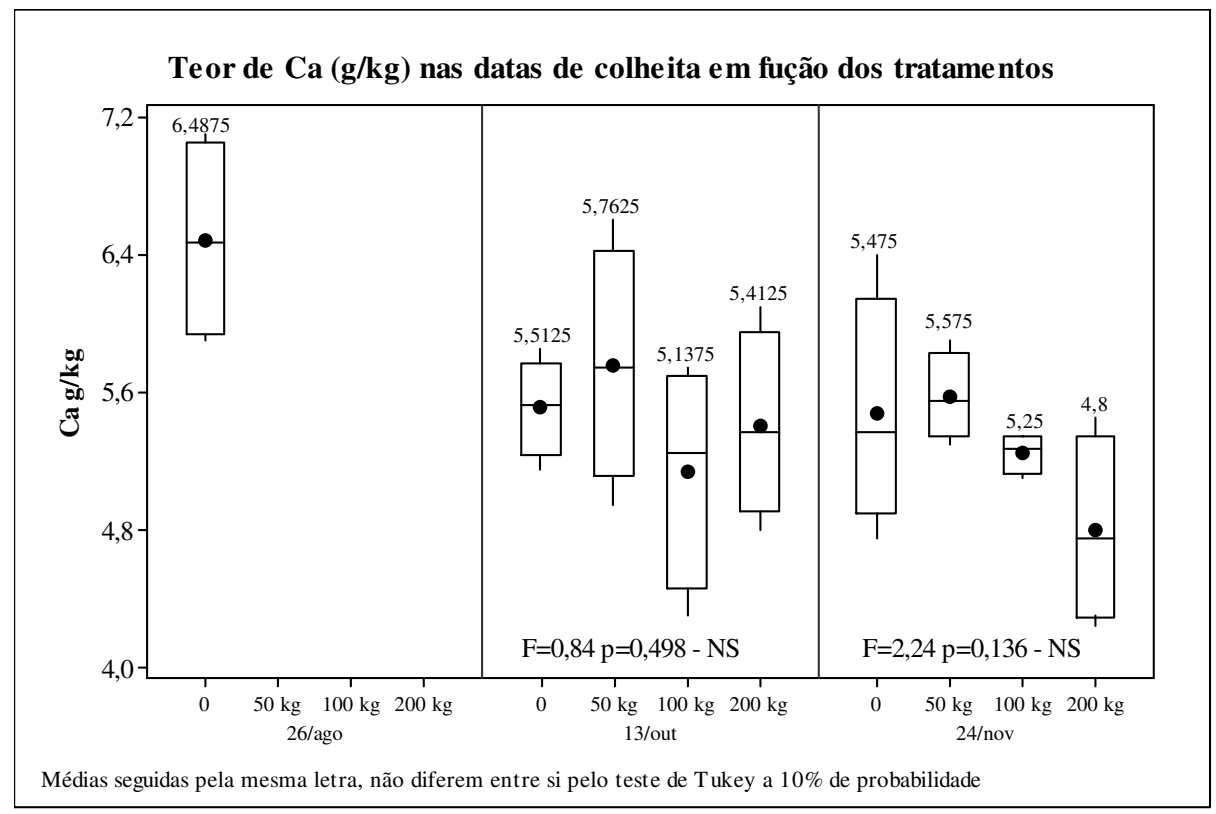

Figura 24 - Evolução dos teores foliares de Ca em função dos tratamentos e datas 


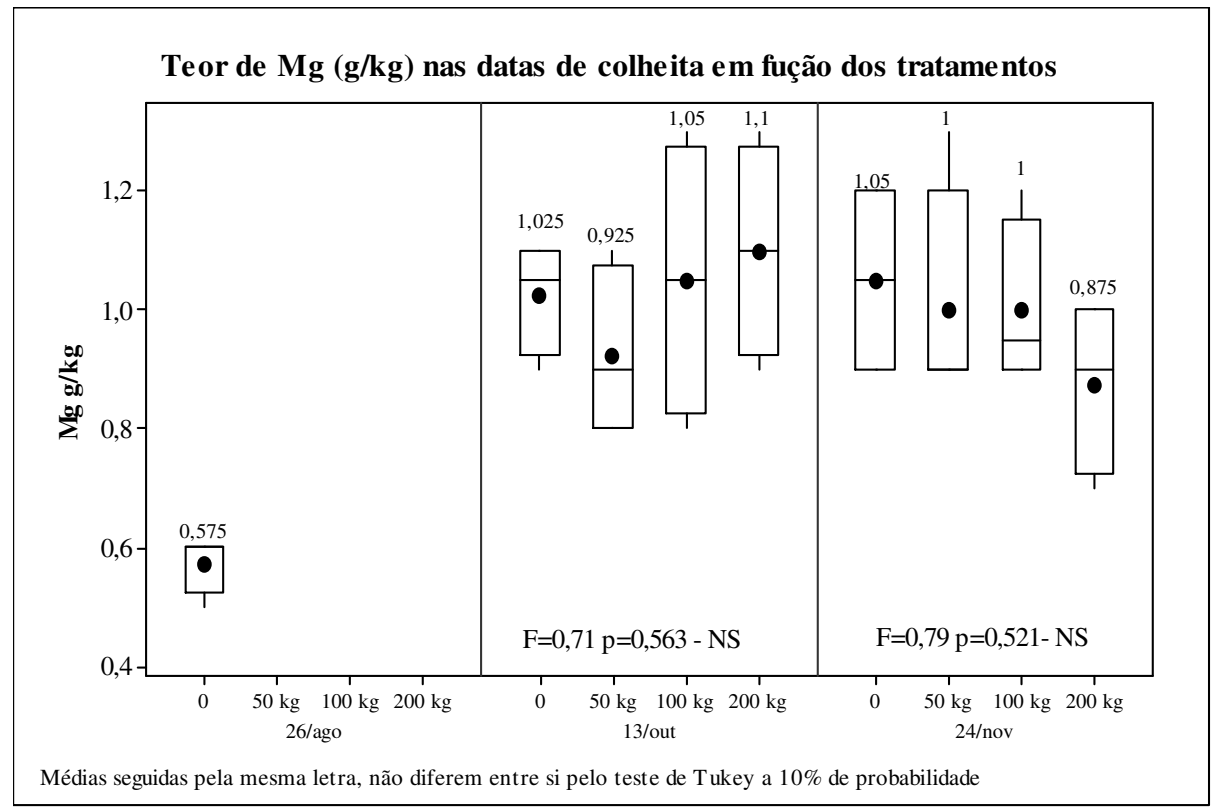

Figura 25 - Evolução dos teores foliares de $\mathrm{Mg}$ em função dos tratamentos e datas

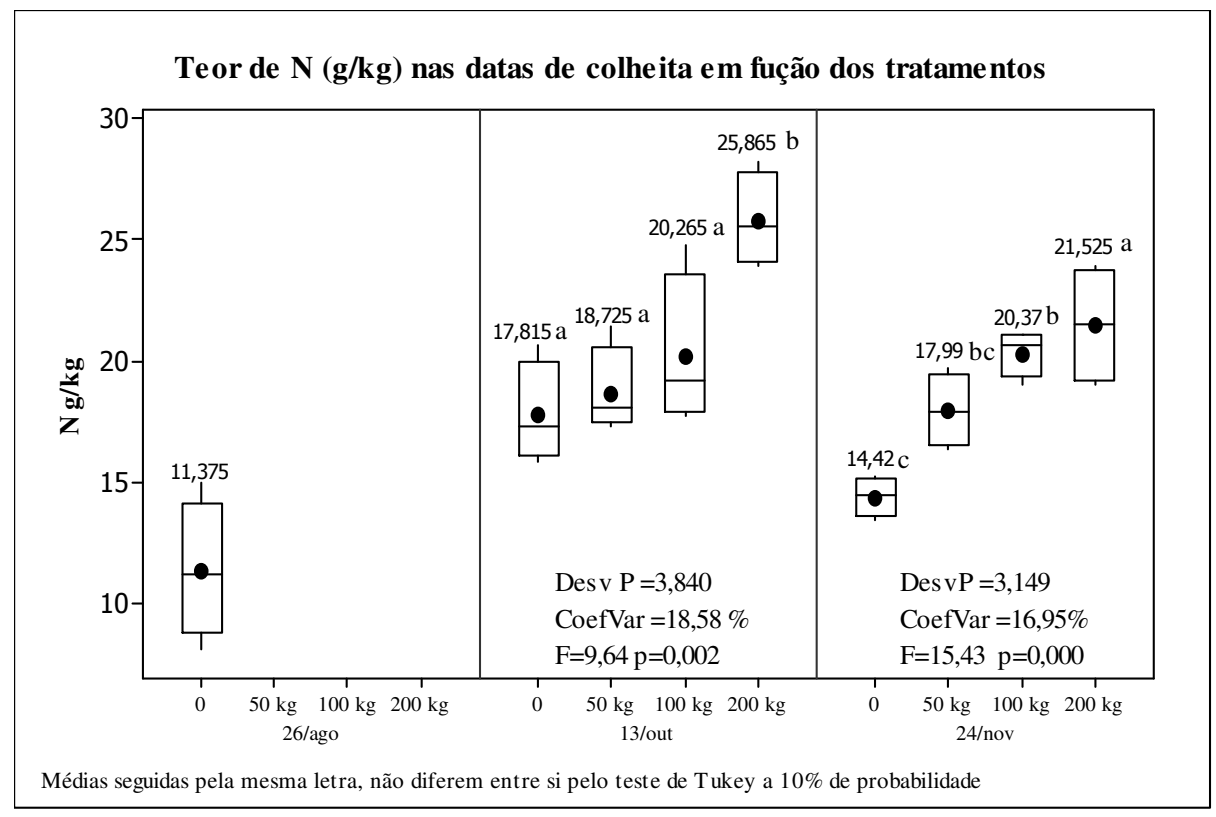

Figura 26 - Evolução dos teores foliares de $\mathrm{N}$ em função dos tratamentos e datas 


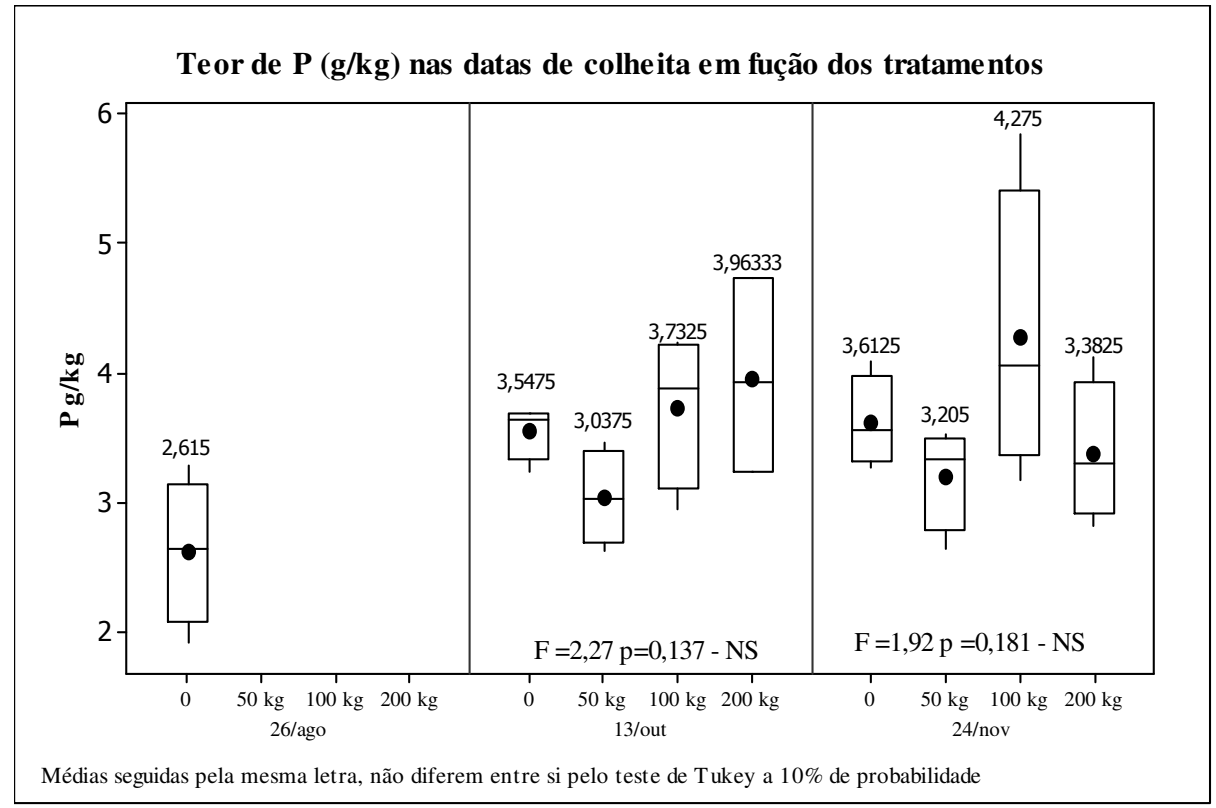

Figura 27 - Evolução dos teores foliares de P em função dos tratamentos e datas

Teor de $\mathrm{S}$ (g/kg) nas datas de colheita em fução dos tratamentos

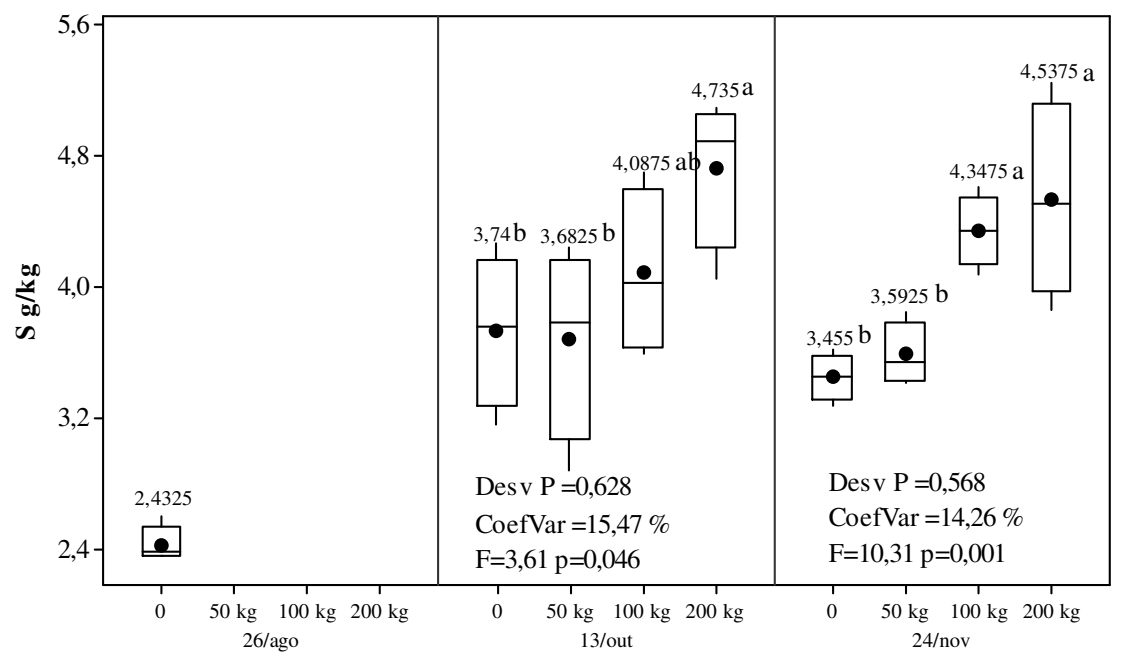

Médias seguidas pela mesma letra, não diferem entre si pelo teste de Tukey a 10\% de probabilidade

Figura 28 - Evolução dos teores foliares de $\mathrm{S}$ em função dos tratamentos e datas 
Em função dos teores foliares e produção de matéria seca, calculou-se a exportação de Na, K, Ca, Mg e N, cujos dados encontram-se na Tabela 15.

As análises estatísticas para as exportações de $\mathrm{Na}$ demonstram diferenças significativas entre os tratamentos, tanto em 13 de outubro quanto em 24 de novembro (Figura 29), que resultam da resposta de produção do capim e enriquecimento em Na.

A colheita possibilitou uma capacidade de exportação em 24 de novembro de aproximadamente $26,7 \mathrm{~kg} \cdot \mathrm{ha}^{-1}$, sem fertilizante nitrogenado, para 82,94 kg.ha ${ }^{-1}$ da dose de $100 \mathrm{~kg} \cdot \mathrm{ha}^{-1}$ de $\mathrm{N}$ e $\mathrm{K}_{2} \mathrm{O}$ em cada corte, confirmando a informação de Mazza \& Aloisi no item3.5. A capacidade total de extração, somando os dois cortes, chega a $120 \mathrm{~kg} \cdot \mathrm{ha}^{-1}$, o que equivale a irrigações totalizando $200 \mathrm{~mm}$ de efluente com $60 \mathrm{ppm}$ de $\mathrm{Na}$ em média.

Embora não significativa, há uma tendência de queda no teor foliar em $\mathrm{Na}$, na maior dose. $\mathrm{O}$ excesso de $\mathrm{K}$ no sistema poderia estar provocando competição na absorção entre os elementos. Estudos mais específicos poderiam ser conduzidos para esclarecer esta hipótese.

Considerando o volume total de efluente gerado pela indústria, pode-se determinar se o manejo com capim seria suficiente para exportar todo o $\mathrm{Na}$ oriundo do descarte na Fazenda Trindade:

$$
\text { Vol.total } \times \operatorname{ano}^{-1}\left(\mathrm{~m}^{3}\right)=q \times h \times d \times f
$$

Onde,

$\mathrm{q}=$ vazão horária do efluente $\left(\mathrm{m}^{3}\right)=300$

$\mathrm{h}=$ número de horas por turno da fábrica $=24$

$\mathrm{d}=$ duração da safra em dias $=210$

$\mathrm{f}=$ fator que considera paradas na operação $=0,8$

Aplicando-se os valores, temos um volume total de $1,2096.10^{6} \mathrm{~m}^{3}$.anoConsiderando ainda que a fazenda dispõe de 400 ha para destinação desta quantidade de efluente, tem-se:

$$
1,2096.10^{6} m^{3} \div 400 h a^{-1}=3024 m^{3} \cdot h a^{-1}
$$


Se a irrigação de $1 \mathrm{~mm}$ de lâmina em um ha corresponde a $10 \mathrm{~m}^{3}$ tem-se a seguinte quantidade de efluente a ser irrigada sobre uma superfície de 1 ha:

$$
3024 \frac{m 3}{h a} \times 1 \mathrm{~mm} \times \frac{1}{10 m^{3}}=302,4 m m \cdot h a^{-1}
$$

O volume a ser irrigado em cada ha seria de $302,4 \mathrm{~mm}$, correspondendo a um total de $180 \mathrm{~kg} \cdot \mathrm{ha}^{-1}$ de $\mathrm{Na}$, mantidas as concentrações de $\mathrm{Na}$ em $60 \mathrm{ppm}$ (ou conforme as apresentadas neste estudo). Como em dois cortes o capim pôde exportar $120 \mathrm{~kg}^{-\mathrm{ha}^{-1}}$, ou seja, $66 \%$ do potencial total de aplicação, pode-se inferir que em 5 cortes todo Na seria retirado do solo pelas plantas.

Para $\mathrm{N}$ e $\mathrm{K}$, cujos teores foliares são altos, as quantidades exportadas foram numericamente elevadas, se comparadas com o Na. Entretanto, pouco Ca e Mg foram exportados. Vale mencionar que quase $100 \mathrm{~kg}$ de cálcio foram aplicados pelo efluente, $\mathrm{o}$ que deve provocar em longo prazo um aumento no teor de Ca do solo, mantida a exportação promovida pelo capim.

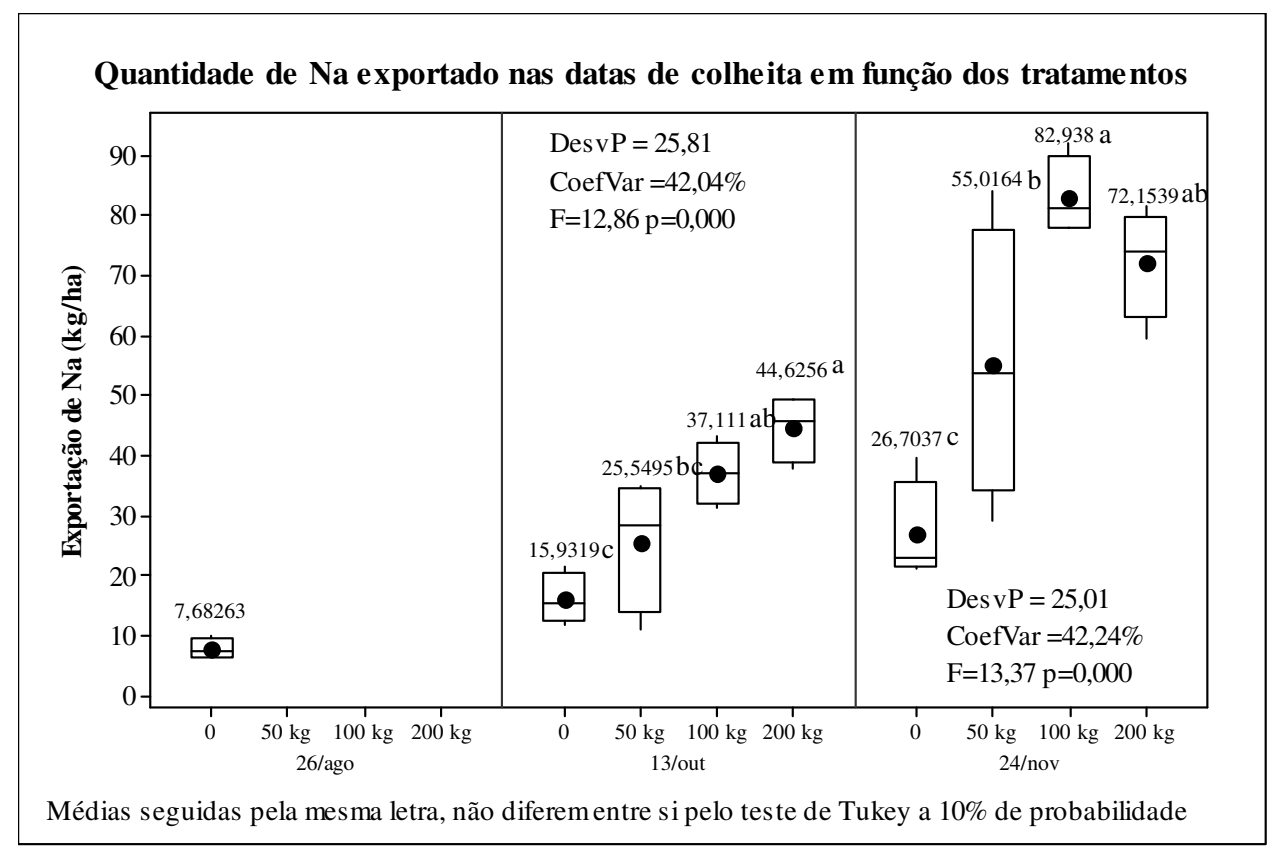

Figura 29 - Exportação de $\mathrm{Na}$ em função dos tratamentos e datas 
Tabela 15 . Exportações de $\mathrm{Na}, \mathrm{K}, \mathrm{Ca}, \mathrm{Mg}$ e $\mathrm{N}\left(\mathrm{kg} \cdot \mathrm{ha}^{-1}\right)$ em função das doses de fertilizantes e datas de colheita

\begin{tabular}{|c|c|c|c|c|}
\hline $\begin{array}{l}\text { 26/ Agosto } \\
\text { (remanescente } \\
\text { de inverno) }\end{array}$ & $\begin{array}{l}\text { Tratamento }(\mathrm{kg} \\
\left.\mathrm{Ne} \mathrm{K}_{2} \mathrm{O} \cdot \mathrm{ha}^{-1}\right)\end{array}$ & $\begin{array}{c}\text { A } \\
\text { 13/Outubro }\end{array}$ & $\begin{array}{c}\text { B } \\
\text { 24/Novembro }\end{array}$ & $\begin{array}{r}\text { Total } \\
(\mathrm{A}+\mathrm{B})\end{array}$ \\
\hline \multicolumn{2}{|l|}{$\mathrm{Na}\left(\mathrm{kg} \cdot \mathrm{ha}^{-1}\right)$} & \multicolumn{3}{|c|}{--_e-- } \\
\hline 7,68 & 0 & $15,93 \mathrm{c}$ & $26,70 \mathrm{c}$ & 42,63 \\
\hline- & 50 & $25,55 \mathrm{bc}$ & $55,02 \mathrm{~b}$ & 80,57 \\
\hline- & 100 & $37,11 \mathrm{ab}$ & 82,94 a & 120,05 \\
\hline \multirow[t]{4}{*}{-} & \multirow[t]{4}{*}{200} & $44,63 \mathrm{a}$ & $72,15 \mathrm{ab}$ & \multirow[t]{4}{*}{116,78} \\
\hline & & DesvP $=12,95$ & DesvP $=25,01$ & \\
\hline & & CoefVar $=42,04 \%$ & CoefVar $=42,24 \%$ & \\
\hline & & $\mathrm{F}=12,86 \mathrm{p}=0,000$ & $\mathrm{~F}=13,37 \mathrm{p}=0,000$ & \\
\hline \multicolumn{2}{|l|}{$\mathrm{K}\left(\mathrm{kg} \cdot \mathrm{ha}^{-1}\right)$} & \multicolumn{3}{|c|}{ 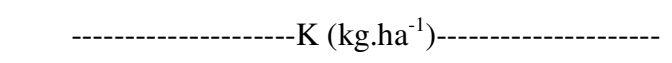 } \\
\hline 7,21 & 0 & $34,38 \mathrm{c}$ & 67,65 & 102,03 \\
\hline- & 50 & $43,88 \mathrm{bc}$ & 82,49 & 126,37 \\
\hline - & 100 & $65,79 \mathrm{ab}$ & 98,67 & 164,46 \\
\hline \multirow[t]{4}{*}{ - } & \multirow[t]{4}{*}{200} & $69,12 \mathrm{a}$ & 83,24 & \multirow[t]{4}{*}{152,36} \\
\hline & & DesvP $=19,25$ & & \\
\hline & & CoefVar $=36,13 \%$ & NS & \\
\hline & & $\mathrm{F}=6,36 \mathrm{p}=0,008$ & $\mathrm{~F}=1,89 \mathrm{p}=0,185$ & \\
\hline \multicolumn{2}{|l|}{$\mathrm{Ca}\left(\mathrm{kg} \cdot \mathrm{ha}^{-1}\right)$} & \multicolumn{3}{|c|}{ 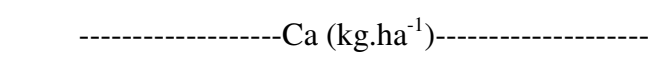 } \\
\hline 9,46 & 0 & $10,08 \mathrm{~b}$ & 18,36 & 28,44 \\
\hline- & 50 & $13,51 \mathrm{ab}$ & 26,06 & 39,57 \\
\hline - & 100 & $14,79 a b$ & 25,11 & 39,89 \\
\hline \multirow[t]{4}{*}{-} & 200 & $18,42 \mathrm{a}$ & 23,82 & 42,24 \\
\hline & & DesvP $=4,15$ & & \\
\hline & & CoefVar $=29,23 \%$ & NS & \\
\hline & & $\mathrm{F}=4,90 \mathrm{p}=0,019$ & $\mathrm{~F}=2,19 \mathrm{p}=0,142$ & \\
\hline
\end{tabular}


Tabela 15 . Exportações de $\mathrm{Na}, \mathrm{K}, \mathrm{Ca}, \mathrm{Mg}$ e N $\left(\mathrm{kg} \cdot \mathrm{ha}^{-1}\right)$ em função das doses de fertilizantes e datas de colheitaas

\begin{tabular}{|c|c|c|c|c|}
\hline $\begin{array}{c}\text { 26/ Agosto } \\
\text { (remanescente } \\
\text { de inverno) }\end{array}$ & $\begin{array}{l}\text { Tratamento }(\mathrm{kg} \\
\left.\mathrm{N} \text { e } \mathrm{K}_{2} \mathrm{O} \cdot \mathrm{ha}^{-1}\right)\end{array}$ & $\begin{array}{c}\text { A } \\
\text { 13/Outubro }\end{array}$ & $\begin{array}{c}\text { B } \\
\text { 24/Novembro }\end{array}$ & $\begin{array}{c}\text { Total } \\
(\mathrm{A}+\mathrm{B})\end{array}$ \\
\hline $\operatorname{Mg}\left(\mathrm{kg} \cdot \mathrm{ha}^{-1}\right)$ & \multicolumn{4}{|c|}{ 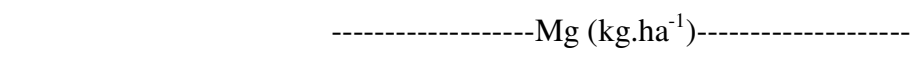 } \\
\hline 0,83 & 0 & $1,88 \mathrm{c}$ & 3,56 & 5,44 \\
\hline- & 50 & $2,14 \mathrm{bc}$ & 4,56 & 6,70 \\
\hline- & 100 & $3,06 \mathrm{ab}$ & 4,78 & 7,84 \\
\hline \multirow[t]{4}{*}{-} & 200 & $3,69 \mathrm{a}$ & 4,26 & 7,95 \\
\hline & & DesvP $=0,952$ & & \\
\hline & & CoefVar $=35,34 \%$ & NS & \\
\hline & & $\mathrm{F}=6,46 \mathrm{p}=0,008$ & $\mathrm{~F}=1,80 \mathrm{p}=0,200$ & \\
\hline \multicolumn{2}{|l|}{$\mathrm{N}\left(\mathrm{kg} \cdot \mathrm{ha}^{-1}\right)$} & \multicolumn{3}{|c|}{ 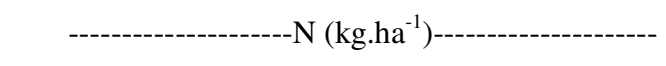 } \\
\hline 16,70 & 0 & $32,55 \mathrm{c}$ & $48,12 \mathrm{c}$ & 80,67 \\
\hline- & 50 & $45,16 \mathrm{bc}$ & $83,68 \mathrm{~b}$ & 128,84 \\
\hline- & 100 & $57,80 \mathrm{~b}$ & $97,20 \mathrm{ab}$ & 155,00 \\
\hline \multirow[t]{4}{*}{-} & 200 & $88,01 \mathrm{a}$ & $106,10 \mathrm{a}$ & 194,11 \\
\hline & & DesvP $=24,31$ & DesvP $=24,31$ & \\
\hline & & CoefVar $=43,51 \%$ & CoefVar $=43,51 \%$ & \\
\hline & & $\mathrm{F}=13,00 \mathrm{p}=0,000$ & $\mathrm{~F}=13,68 \mathrm{p}=0,000$ & \\
\hline
\end{tabular}

A Tabela 16 compara as informações de aplicação e exportação dos cinco principais elementos do sistema: $\mathrm{Na}, \mathrm{K}, \mathrm{Ca}, \mathrm{Mg}$ e N. Conclui-se que todos foram colocados em excesso, exceto o $\mathrm{Na}$, que teve sua exportação maior do que a quantidade aplicada, nas parcelas com qualquer dose de fertilizante.

É fato que, a partir de $100 \mathrm{~kg} \cdot \mathrm{ha}^{-1}$ de $\mathrm{N}$ e $\mathrm{K}_{2} \mathrm{O}$, o capim retirou todo o $\mathrm{Na}$ que foi colocado via irrigação e mais, pelo menos, $38 \mathrm{~kg}$, cuja origem seja provavelmente o estoque do solo. Este fato comprova que o Capim-de-rhodes pode atuar como ferramenta na bio-remediação do solo. Ao longo dos anos, haveria uma melhora na estrutura do solo, pelo aporte de $\mathrm{Ca}$ e desenvolvimento do sistema radicular (conseqüentemente aumento na MO), possibilitando a manutenção dos teores de $\mathrm{Na}$ no solo em valores bastante reduzidos, mesmo considerando os freqüentes aportes realizados atualmente. 
Não seria possível afirmar que todos os nutrientes aplicados estiveram disponíveis à absorção. Raij (1991) descreve que os fertilizantes apresentam diferentes eficiências, de forma que nem toda a quantidade aplicada poderá ser absorvida pela planta, devido a perdas por volatilização, lixiviação, etc. Isso leva a crer que, assim como para os fertilizantes, os nutrientes contidos no efluente podem apresentar diferentes eficiências. Estudos mais específicos poderiam ser realizados para determinar essa eficiência, a fim de entender melhor os benefícios do efluente como fornecedor de nutrientes. 
Tabela 16 . Comparativo entre total de $\mathrm{Na}, \mathrm{K}, \mathrm{Ca}, \mathrm{Mg}$ e $\mathrm{N}\left(\mathrm{kg}^{\mathrm{h}} \mathrm{ha}^{-1}\right)$ fornecidos e exportados ao final do experimento

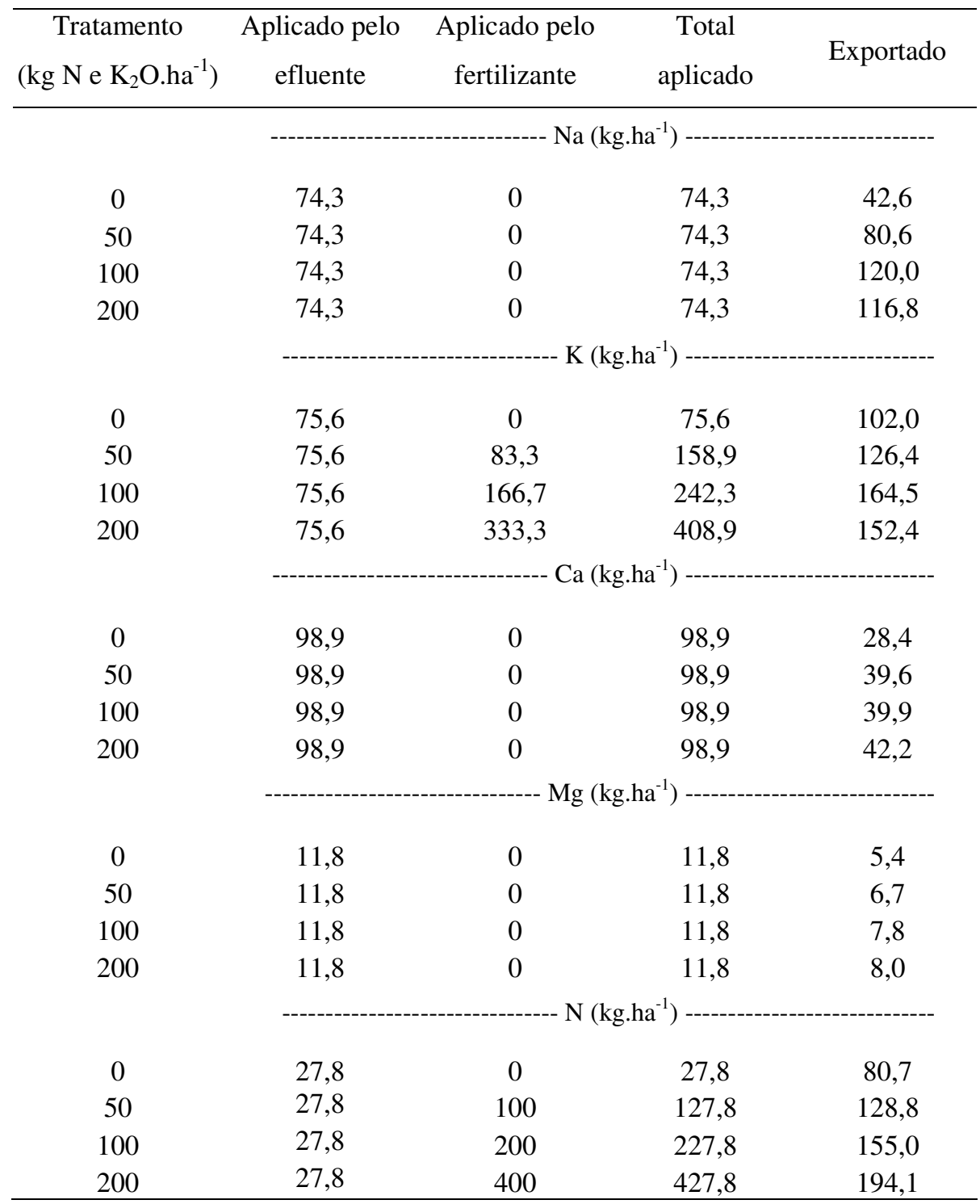




\subsection{Monitoramento dos parâmetros do solo}

\subsubsection{Monitoramento da Fazenda Trindade no período de 2001 a 2002}

A Tabela 17 contém dados de análises de solo em Setembro de 2001, no final da estação seca (que inclui o período de maior acúmulo de $\mathrm{Na}$ e déficit hídrico), e em Maio de 2002, depois da estação chuvosa (excedente hídrico), de uma área que recebeu irrigação com efluente por 4 anos. Nota-se que a saturação por sódio atinge valores elevados em Setembro de 2001. Estes valores enquadrariam o solo no caráter sódico (Embrapa, 1999), sem, contudo, ocorrer perda de capacidade produtiva, conforme observado nos cultivos de pupunha e capim-de-rhodes.

É fato que, por se tratar de um Argissolo, formado a partir de um arenito do Grupo Bauru (IPT, 1981), cujo material já é muito intemperizado, espera-se no solo um predomínio de minerais de argila de estrutura 1:1, óxidos e hidróxidos de Fe e Al. Em função destas características mineralógicas, a CTC é baixa se compararmos com os solos menos intemperizados do hemisfério norte, de onde derivam os critérios de caracterização quanto ao PST. Pode-se entender facilmente que o teor absoluto de $\mathrm{Na}$ trocável para as condições do Argissolo em questão é muito menor do que num solo de CTC elevada, para um mesmo PST. Portanto, o PST elevado não deve indicar, nas condições citadas, perda da capacidade produtiva.

Outra importante informação contida nestes dados é a evidência da grande mobilidade do $\mathrm{Na}$ no solo. O PST decresceu, em média, de 16 para 1,25, respectivamente em setembro de 2001 e maio de 2002, nos primeiros $40 \mathrm{~cm}$ de profundidade. Calculando-se a variação da quantidade de Na por área $\left(\mathrm{kg} \cdot \mathrm{ha}^{-1}\right)$, tem-se uma diminuição de $1400 \mathrm{~kg} \cdot \mathrm{ha}^{-1}$ na camada de 0-40 cm; provavelmente, grande parte desta redução devida à lixiviação. 
Tabela 17 . Evolução dos parâmetros químicos do solo da Fazenda Trindade em duas épocas: setembro de 2001 e maio de 2002

\begin{tabular}{|c|c|c|c|c|c|c|c|c|c|c|c|c|c|}
\hline \multirow{2}{*}{$\begin{array}{l}\text { Prof. } \\
\mathrm{cm}\end{array}$} & \multicolumn{2}{|c|}{$\mathrm{pH}$} & \multirow{2}{*}{$\begin{array}{l}\text { M.O } \\
\text { g kg}^{-1}\end{array}$} & \multirow{2}{*}{$\begin{array}{c}\mathrm{P} \\
\mathrm{mg} \mathrm{kg}^{-1}\end{array}$} & \multirow[t]{2}{*}{$\mathrm{Na}$} & \multirow[t]{2}{*}{$\mathrm{K}$} & \multirow{2}{*}{\multicolumn{3}{|c|}{$\begin{array}{c}\mathrm{Ca} \mathrm{Mg} \mathrm{H}+\mathrm{Al} \\
\text { mmolc kg-1 }\end{array}$}} & \multirow[t]{2}{*}{ SB } & \multirow[t]{2}{*}{$\mathrm{T}$} & \multirow{2}{*}{\multicolumn{2}{|c|}{$\begin{array}{c}\mathrm{V} \mathrm{Na} \\
\% \\
\end{array}$}} \\
\hline & $\mathrm{H}_{2} \mathrm{O}$ & $\mathrm{CaCl}_{2}$ & & & & & & & & & & & \\
\hline \multicolumn{14}{|c|}{ Setembro 2001} \\
\hline $0-20$ & 7,9 & 5,8 & 20 & 46 & 13,00 & 4,9 & 41 & 10 & 10 & 68,9 & 78,9 & 87 & 16 \\
\hline $20-40$ & 6,4 & 5,0 & 10 & 3 & 8,80 & 3,3 & 14 & 7 & 22 & 33,1 & 55,1 & 60 & 16 \\
\hline $80-100$ & 7,5 & 5,8 & 8 & 4 & 9,00 & 4,1 & 27 & 10 & 20 & 50,1 & 70,1 & 71 & 13 \\
\hline $130-150$ & 6,8 & 5,5 & 6 & 4 & 6,80 & 1,5 & 22 & 8 & 19 & 38,3 & 57,3 & 67 & 12 \\
\hline \multicolumn{14}{|c|}{ Maio 2002} \\
\hline $0-20$ & 6,7 & 5,9 & 22 & 18 & 0,80 & 3,4 & 34 & 7 & 15 & 44,4 & 59,4 & 75 & 1,3 \\
\hline $20-40$ & 6,9 & 6,1 & 15 & 26 & 0,70 & 3,8 & 34 & 7 & 13 & 44,8 & 57,8 & 78 & 1,2 \\
\hline $80-100$ & 6,8 & 6,0 & 10 & 33 & 3,70 & 5,8 & 29 & 8 & 16 & 42,8 & 58,8 & 73 & 6,3 \\
\hline $130-150$ & 6,9 & 6,2 & 5 & 3 & 3,20 & 2,4 & 26 & 7 & 15 & 35,4 & 50,4 & 70 & 6,3 \\
\hline
\end{tabular}

Fonte: Grupo Fisher

\subsubsection{Monitoramento do solo no período experimental}

Nas análises realizadas nas amostras de solo coletadas em 26 de Agosto de 2003, pôde-se verificar uma pequena variação entre os blocos, mas uma sensível diferença em função das profundidades (Figura 30), confirmando a informação do monitoramento anterior, onde os maiores teores encontravam-se nas maiores profundidades (Tabela 17).

O mesmo efeito é evidenciado em termos de PST (Figura 31), agravado pela menor CTC em profundidade, o que conferiu maior participação do Na no complexo de troca do solo. Comparando com a situação histórica, percebe-se que a área do ensaio assemelhava-se muito com aquela dos dados históricos de Setembro de 2001, apesar de apresentar menor teor de $\mathrm{Na}$, por ter sido adquirida recentemente pela empresa e, portanto, ter recebido menos efluente. 


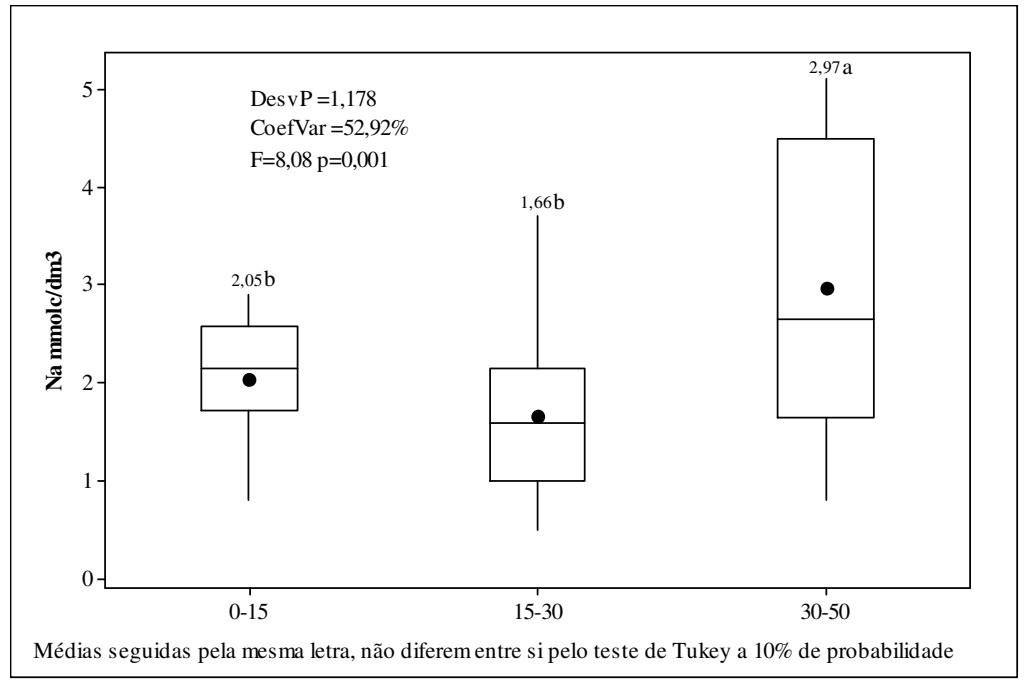

Figura 30 - Variação dos teores de Na no solo em função da profundidade $(\mathrm{cm})$, em 26/Agosto, antes da instalação do ensaio

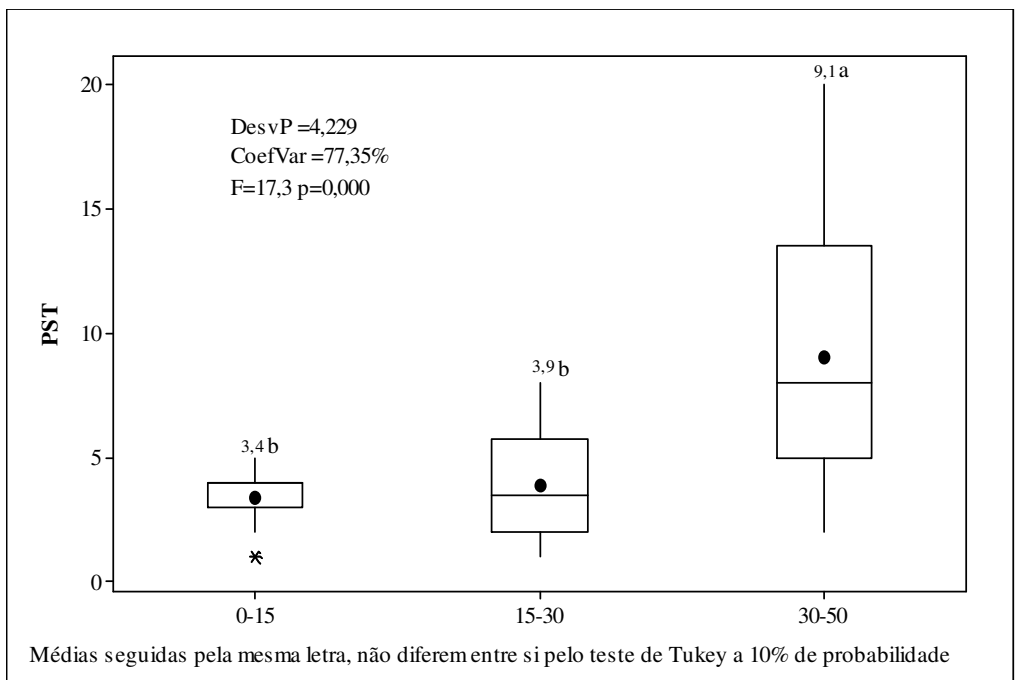

Figura 31 - Variação do PST no solo em função da profundidade, em 26/Agosto, antes da instalação do ensaio 
Considerando-se, portanto, o solo como o principal objeto deste estudo, os resultados experimentais demonstram que as exportações promovidas pelo Capim-de-rhodes permitiram uma mudança significativa nos teores de Na no solo na profundidade de 0-15 $\mathrm{cm}$, após o segundo corte de capim. Comparando-se as datas de amostragem, percebe-se que a resposta aos tratamentos aparecem como tendência em 13 de outubro e confirmase de forma significativa em 24 de novembro (Figura 32). Poder-se-ia inferir, ainda, que, num terceiro corte, a redução nos teores seria ainda maior e mais clara, devido à época, que permite grande desenvolvimento vegetativo do capim.

Ao longo das demais profundidades (Figura 33 e Figura 34), o efeito dos tratamentos não se evidencia, a não ser por uma ligeira tendência de redução do teor de $\mathrm{Na}$ na profundidade de 15-30 $\mathrm{cm}$ após o segundo corte. Nada, entretanto, pode-se dizer sobre a profundidade de $30-50 \mathrm{~cm}$, onde a variação dos teores manteve-se nos padrões observados no início do experimento.

Espera-se ao longo do tempo, mantendo-se o sistema implementado, que o capim continue desenvolvendo seu sistema radicular, aprofundando o efeito da absorção de sódio e provocando uma melhoria na condutividade hidráulica do solo. A partir de então, sugere-se que a remediação atinja as camadas mais profundas do solo.

A análise dos dados de $0-15 \mathrm{~cm}$ de profundidade em termos de cálcio mostrou uma forte tendência a aumento do teor ao longo das datas, comprovando a hipótese discutida no item 4.3, onde a pequena exportação do elemento em contrapartida ao grande aporte pelo efluente deveria enriquecer o solo (Figura 35).

Para o potássio, houve uma pequena resposta em termos de enriquecimento do solo (não significativa), nas maiores doses, em 24 de Novembro, na profundidade de 0-15 $\mathrm{cm}$. Como os teores de potássio são numericamente muito baixos, verificaram-se maiores variações nos resultados das análises e, portanto, obtiveram-se dados de difícil interpretação. De qualquer forma, houve uma tendência de aumento do teor em todos os tratamentos (devido ao aporte do efluente), verificada a partir de 13 de outubro, com alguma diferenciação nas maiores doses, principalmente em 24 de novembro (Figura 36). Os dados nas demais profundidades não foram consistentes, assim como não o foram para o Na. 
Analisando-se paralelamente o comportamento do sódio e do potássio, observa-se certa similaridade. Com certeza, devido às suas características semelhantes em termos de caráter monovalente e raio iônico, que conferem baixa capacidade de adsorção aos colóides do solo e efeito dispersante de argilas (Tan, 1993).

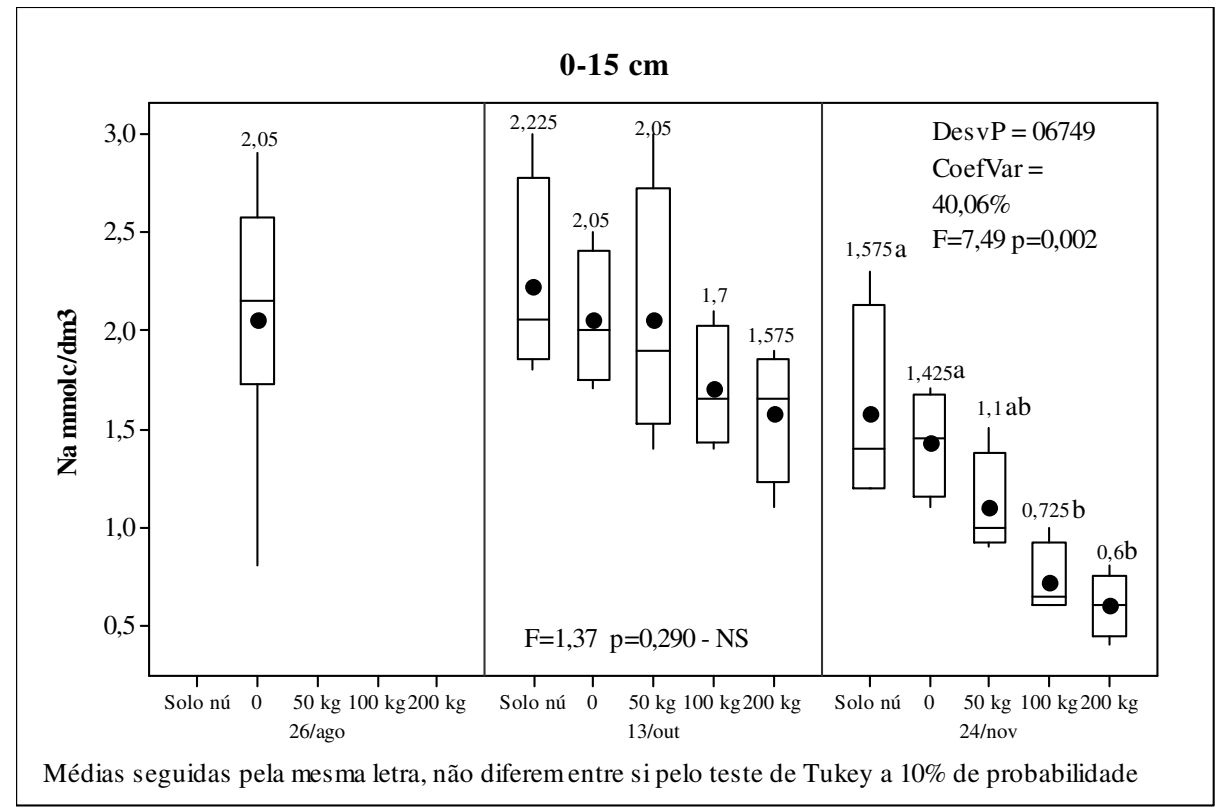

Figura 32 - Teores de Na no solo na profundidade $0-15 \mathrm{~cm}$ ao longo das datas 


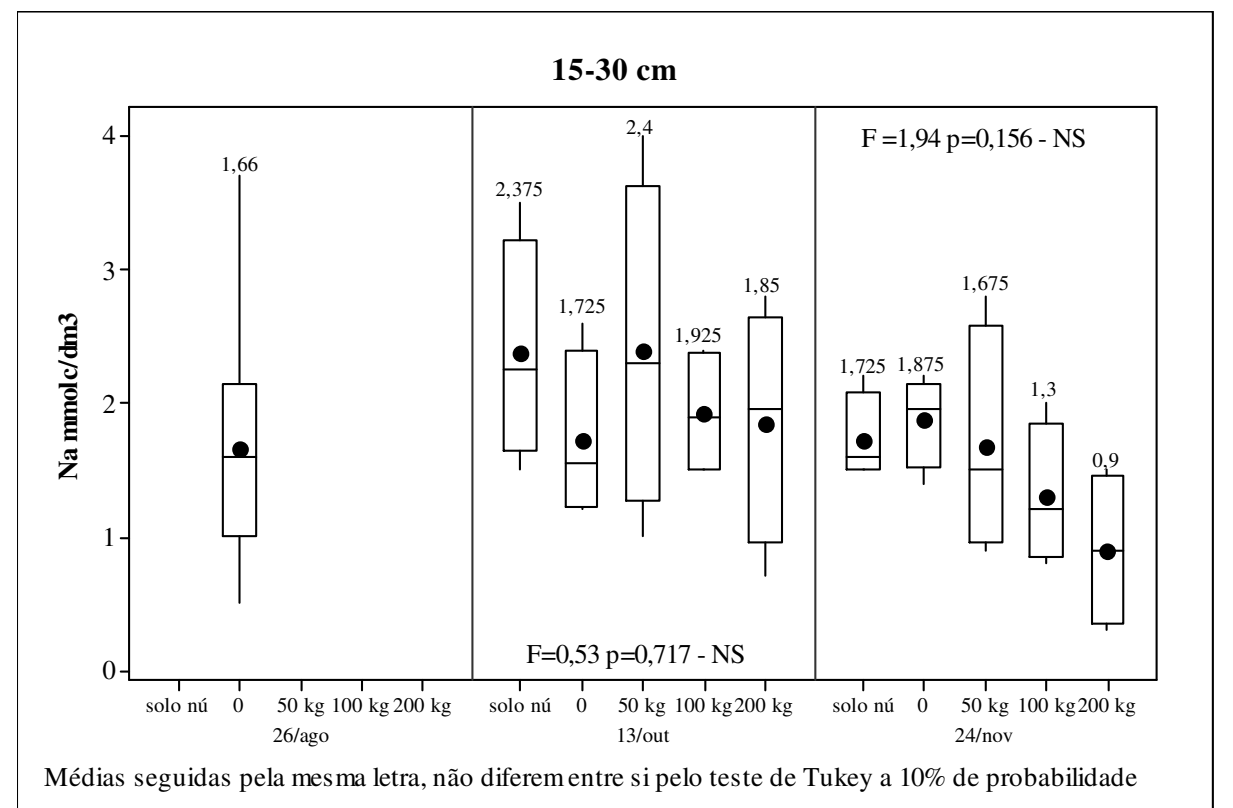

Figura 33 - Teores de Na no solo na profundidade $15-30 \mathrm{~cm}$ ao longo das datas

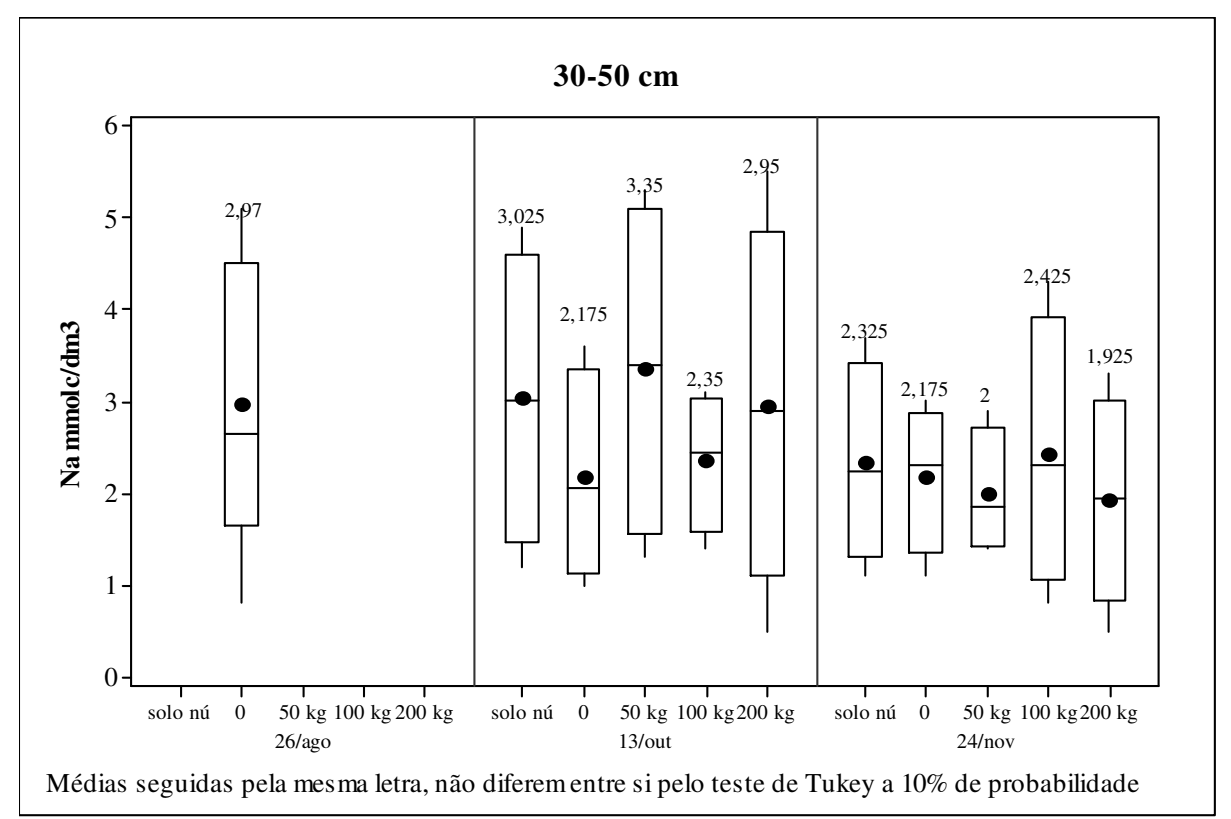

Figura 34 - Teores de Na no solo na profundidade $30-50 \mathrm{~cm}$ ao longo das datas 


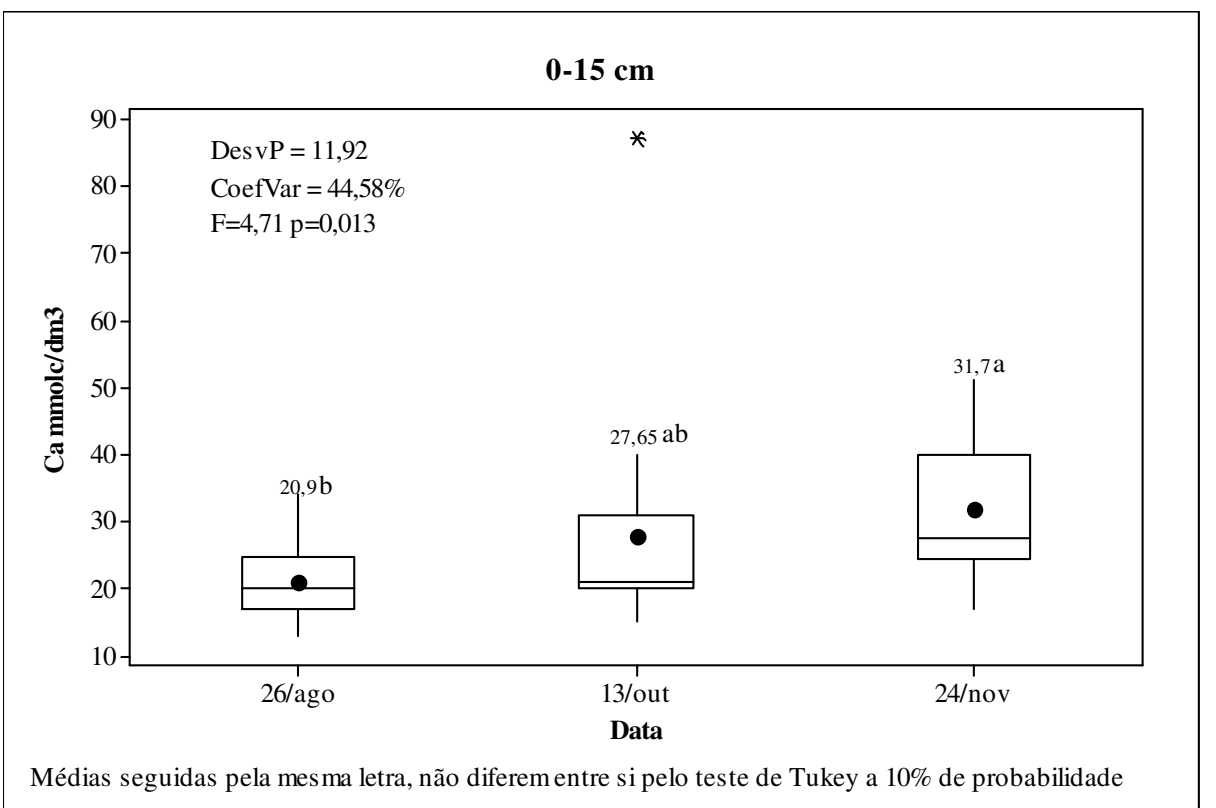

Figura 35 - Teores de Ca no solo de 0-15 $\mathrm{cm}$ de profundidade ao longo das datas

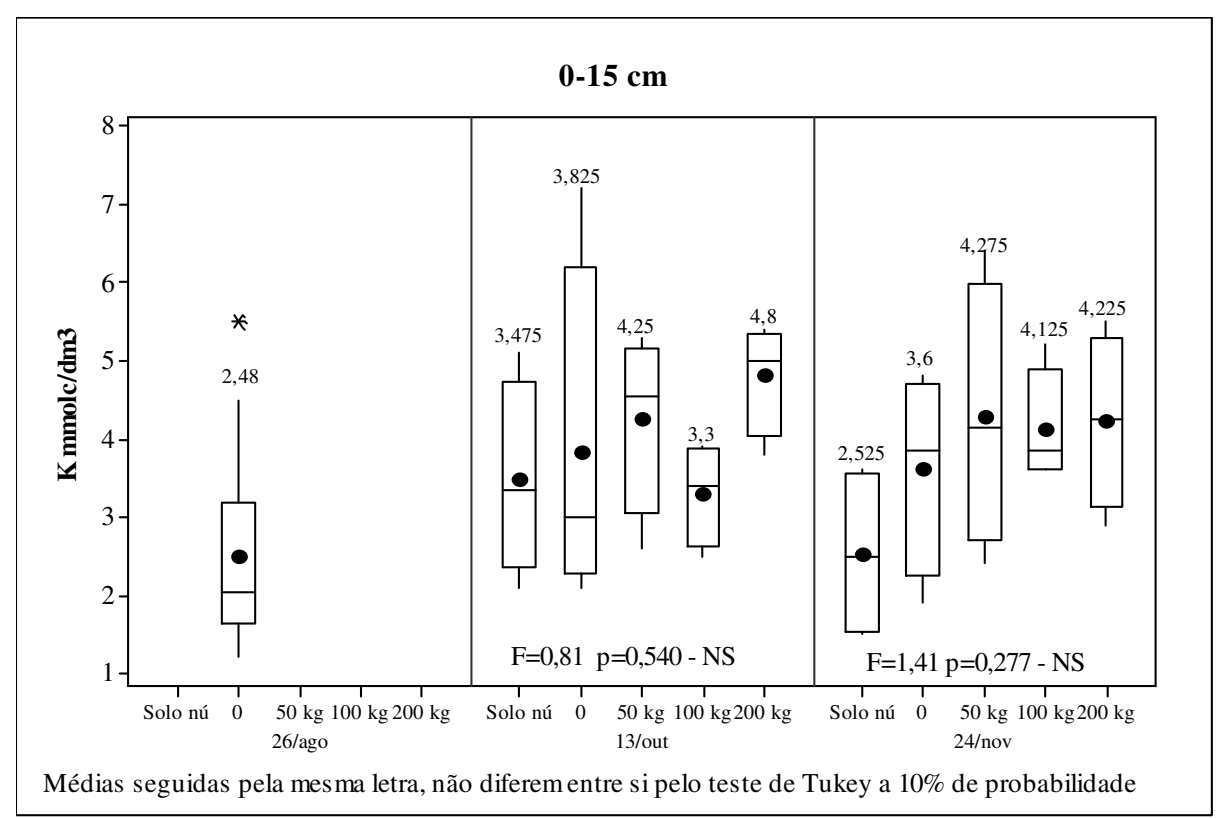

Figura 36 Teores de $\mathrm{K}$ no solo na profundidade $0-15 \mathrm{~cm}$ ao longo das datas 


\subsection{Balanço de sódio no sistema}

O volume de efluente, a exportação e os dados de solo em 26 de agosto e 24 de novembro, permitiram elaborar um balanço aproximado de sódio no sistema delimitado pelo experimento (Tabela 18).

Este cálculo pode indicar, também, o montante de sódio potencialmente lixiviado além dos $50 \mathrm{~cm}$ de profundidade, uma vez que as amostras somente foram retiradas até esta profundidade. Considerando, ainda, que as raízes com grande capacidade de absorção encontram-se concentradas até $40 \mathrm{~cm}$ de profundidade, pode-se inferir que o sódio lixiviado além dos $50 \mathrm{~cm}$ poderá atingir o lençol freático.

Durante o período do ensaio, ocorreram chuvas totalizando $335 \mathrm{~mm}$ (Figura 13). O efeito das chuvas na lavagem do solo foi claramente evidenciado na redução do teor de $\mathrm{Na}$ no solo nas parcelas sem capim, onde não houve exportação, a partir da intensificação da precipitação na segunda metade de outubro.

Tabela 18 . Balanço de sódio na área do experimento, considerando o total aplicado, extraído e as análises de solo

\begin{tabular}{|c|c|c|c|c|c|c|c|}
\hline \multicolumn{2}{|c|}{ Tratamento Aplicado } & $\begin{array}{c}\text { Estoque } \\
\text { no solo } \\
(0-50 \mathrm{~cm})\end{array}$ & $\begin{array}{c}\text { Total } \\
\text { calculado }\end{array}$ & $\begin{array}{l}\text { Extraído } \\
\text { (até } 40 \mathrm{~cm})^{3}\end{array}$ & \multirow{2}{*}{$\begin{array}{c}\text { Remanescente } \\
\text { calculado em } \\
24 / \text { Nov }\end{array}$} & \multirow{2}{*}{$\begin{array}{c}\text { Real } \\
24 / \text { nov. } \\
(0-50 \mathrm{~cm}) \\
\mathrm{F}\end{array}$} & \multirow{2}{*}{$\begin{array}{c}\begin{array}{c}\text { Estimativa } \\
\text { do lixiviado } \\
(>50 \mathrm{~cm})\end{array} \\
\text { E-F }\end{array}$} \\
\hline & A & B & $A+B=C$ & D & & & \\
\hline & \multicolumn{7}{|c|}{$\mathrm{kg} \cdot \mathrm{ha}^{-1}$} \\
\hline test & $\begin{array}{l}74,3 \\
\end{array}$ & 230 & 305 & 0 & 305 & 194 & 111 \\
\hline 0 & 74,3 & 230 & 305 & 43 & 262 & 189 & 73 \\
\hline 50 & 74,3 & 230 & 305 & 81 & 224 & 165 & 59 \\
\hline 100 & 74,3 & 230 & 305 & 120 & 185 & 154 & 31 \\
\hline 200 & 74,3 & 230 & 305 & 117 & 188 & 118 & 70 \\
\hline
\end{tabular}

\footnotetext{
${ }^{3}$ Estimando-se a zona ativa do sistema radicular do capim.
} 
Embora não seja possível aplicar ferramentas estatísticas nos dados (soma das médias das três profundidades), verifica-se claramente que o tratamento de $100 \mathrm{~kg}$ provê uma redução de mais de dois terços (72\%) na quantidade de sódio lixiviado, além dos 50 $\mathrm{cm}$ com relação à testemunha sem capim. A redução da lixiviação com o capim sem fertilizante (situação atualmente praticada na fazenda) limita-se a $38 \mathrm{~kg}^{-h^{-1}}(34 \%)$.

Usando os conceitos da série liotrópica descrita por Tan (1993), poder-se-ia explicar o aumento de lixiviação do Na no tratamento de maior dose $\left(200 \mathrm{~kg} \cdot \mathrm{ha}^{-1}\right)$ em relação ao tratamento com $100 \mathrm{~kg} \cdot \mathrm{ha}^{-1}$ de $\mathrm{N}$ e $\mathrm{K}_{2} \mathrm{O}$. O excesso de $\mathrm{K}$ na solução do solo estaria ocupando um grande número de cargas negativas dos colóides, já que este tem preferência na adsorção em relação ao Na, deixando este último livre para ser lixiviado, mediante ao excesso hídrico verificado. A Figura 37 ilustra a participação relativa das frações, disponível no solo até $50 \mathrm{~cm}$, exportado e lixiviado em cada situação contemplada no experimento.

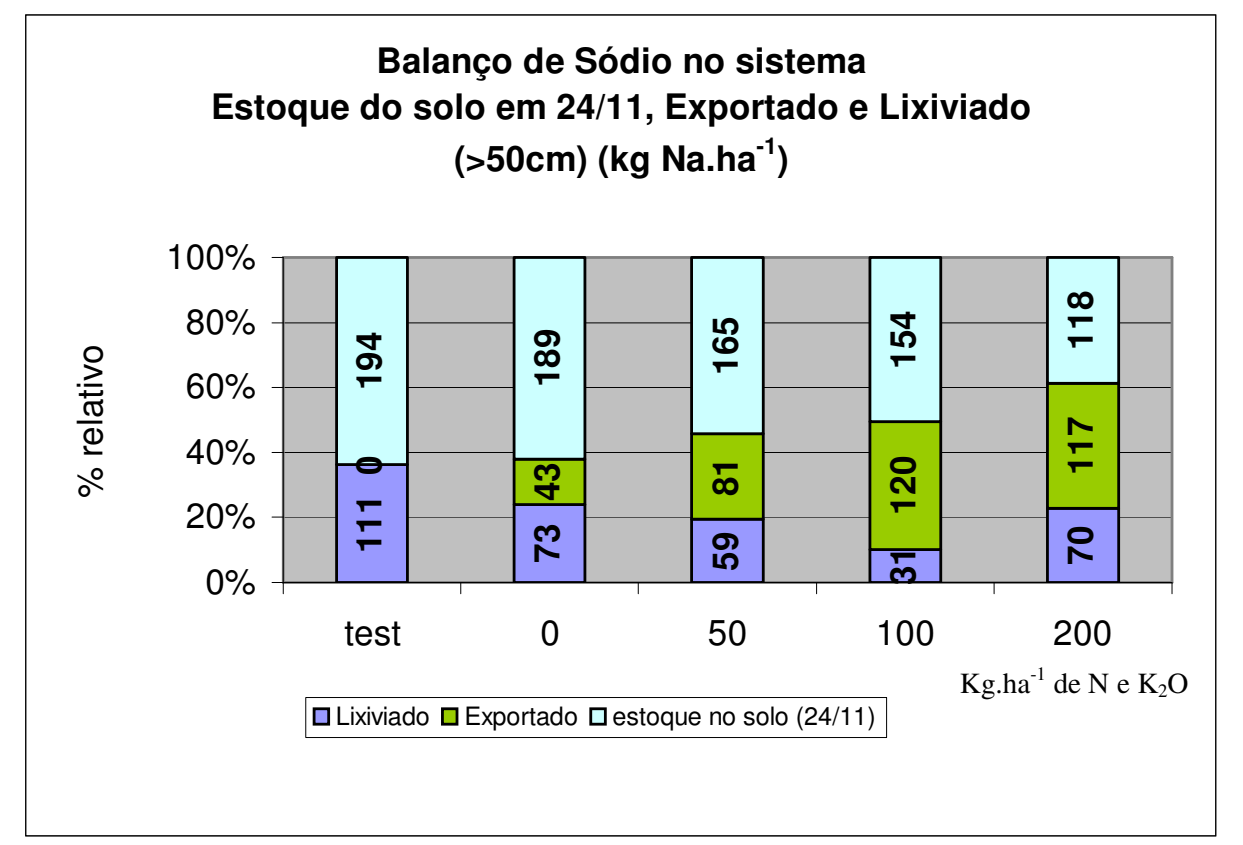

Figura 37 - Participação relativa do montante de sódio, restante no solo após o segundo corte do capim, extraído e lixiviado 


\section{CONCLUSÕES}

$>\mathrm{O}$ manejo do Capim-de-rhodes com fertilização nitrogenada permitiu um melhor rendimento agrícola do mesmo para as condições edafoclimáticas em questão.

$>\mathrm{O}$ teor de $\mathrm{Na}$ no capim foi maior com as maiores doses do fertilizante nitrogenado.

$>\mathrm{O}$ maior teor de $\mathrm{Na}$ no tecido foliar aliado à maior produção de massa com a adubação do Capim-de-rhodes permitiu que o mesmo extraísse quase 3 vezes mais sódio quando comparado com o capim sem fertilizante.

$>$ Houve grande efeito da chuva, como ferramenta de lavagem, na redução do teor de Na no Argissolo Vermelho Amarelo Distrófico latossólico.

$>$ O manejo do capim com fertilizante permitiu uma capacidade de extração maior do que a quantidade de Na aplicada pela irrigação, já a partir da dose mais baixa de 50 kg de N.ha ${ }^{-1}$.

> Com o tratamento de $100 \mathrm{~kg}$ de $\mathrm{N}$ por hectare, a exportação de sódio superou em $40 \%$ o seu fornecimento pelo efluente, indicando que em longo prazo haveria sensível redução do seu teor no solo.

> Ficou validada a hipótese de que o Capim-de-rhodes, desde que fertilizado com nitrogênio, funciona como ferramenta de despoluição do solo e que é possível manter a irrigação com o efluente industrial, sem prejudicar sua capacidade produtiva, evitando o acúmulo de sódio e sua eventual lixiviação para o lençol freático. 


\section{REFERÊNCIAS BIBLIOGRÁFICAS}

ALLISON, L.E. Salinity in relation to irrigation. Advance in Agronomy, n. 16, p. 139180, 1964

ALOISI, R. R. Deposição de resíduos da indústria cítrica em solos de textura média. Piracicaba, 1995. 255p. Tese (Livre-Docência) - Escola Superior de Agricultura "Luiz de Queiroz", Universidade de São Paulo

AYERS, R.S; WESTCOT, D.S. Water quality for agriculture. Rome: FAO, 1985. 174p. (Irrigation and Drainage Paper, 29).

BALKS, M.R.; BOND, W.J.; SMITH, C.J. Effects of sodium accumulation on soil physical properties under an effluent-irrigated plantation. Australian Journal of Soil Research, v.36, p.821-830, 1998.

BATAGliA, O. C.; FURLANI; A. M. C.; TEIXEIRA, J.P.F.; FURLANI; P. R.; GALLO, J. R. Métodos de análises químicas de plantas. Campinas: Instituto Agronômico, 1983. 48 p. (Boletim Técnico, 78)

BOND, W.J. Effluent irrigation - an environmental challenge for soil science. Australian Journal of Soil Research, v.36, p.543-555, 1998.

BOUWER, H.; CHANEY, R.L. Land treatment of wastewater. Advances in Agronomy, v.26, p.133-176, 1974.

BOWER, C.A.; WADLEIGH, C.H. Growth and cationic accumulation by four species of plants as influenced by various levels of exchangeable sodium. Soil Science, v.13, p. 218-223, 1948. 
CHIRINOS, I. J. Variação da condutividade hidráulica do solo saturado em função da concentração de sódio presente em soluções e resíduo agroIndustrial. Piracicaba, 1992. 47p. Dissertação (Mestrado) - Escola Superior de Agricultura "Luiz de Queiroz", Universidade de São Paulo.

EMPRESA BRASILEIRA DE PESQUISA AGROPECUÁRIA. Manual de métodos de análises de solo. 2. ed. Rio de Janeiro: Embrapa-CNPS, 1997. 212 p.

EMPRESA BRASILEIRA DE PESQUISA AGROPECUÁRIA. Sistema Brasileiro de Classificação de Solos. Brasília: Embrapa Produção de Informação, 1999. 412p.

ENVIRONMENT PROTECTION AUTHORITY OF VICTORIA. Guidelines for the disposal of wastewater on land Irrigation. Melbourne: Publication, 1983. 168p.

ENVIRONMENT PROTECTION AUTHORITY OF VICTORIA. Guidelines wastewater Irrigation. Melbourne: Publication, 1991. 85p.

ESTADOS UNIDOS. Environment Protection Agency. Process design manual - land treatment of municipal wastewater. Cincinnati: USEPA, 1981. 150p.

ESTADOS UNIDOS. Department of Agriculture. Agricultural Research Service. Soil and Water Conservation Research Branch. Salinity Laboratory Staff. Diagnosis and Improvement of saline and alkali soils. Washington: USDA, 1954. 160p.

FEIGIN, A.; RAVINA, I.; SHALHEVET, J. Irrigation with treated sewage effluent: management for environmental protection. Berlin: Springer-Verlag, 1991. 224p.

GOMES, F. P. Curso de estatística experimental. Piracicaba: Escola Superior de Agricultura "Luiz de Queiroz", 1963.384p.

GORHAM, J. Sodium content of agricultural crops. In: PHILLIPS, C.J.C.; CHIY, P. C. Sodium in agriculture. Kent: Chalcombe publications, 1995. p. 17:32.

HALLIWELL, D.J.; BARLOW, K.M.; NASH, D.M. A review of the effects of wastewater sodium on soil physical properties and their implications for irrigation systems. Australian Journal of Soil Research, v.39, p.1259-1267, 2001.

HALLIWELL, D.J.; BARLOW, K.M.; NASH, D.M. A review of the effects of wastewater sodium on soil physical properties and their implications for irrigation systems. Australian Journal of Soil Research, v.39, p.1259-1267, 2001. 
HAYWARD, H.E.; WADLEIGH, C.H. Plant growth on saline and alkaline soils. Agronomy Journal, v. 58, n. 2, p. 238-240, 1949

HESPANHOL, I. potencial de reuso de água no Brasil-agricultura, indústria, municípios, recarga de aqüíferos. Revista Brasileira de Recursos Hídricos. v.7, p.75-95, 2002.

INSTITUTO DE PESQUISAS TECNOLÓGICAS DO ESTADO DE SÃO PAULO. Mapa geológico do Estado de São Paulo. São Paulo: IPT, DMGA, 1981. v.1 126 p IRVINE, S.A.; REID, D.J. Field prediction of sodicity in dry land agriculture in central Queensland, Australia. Australian Journal of Soil Research, v.39, p.1349-1357, 2001.

JOHNS G.G.; McCONCHIE, D.M. Irrigation of bananas with secondary treated sewage effluent. ii. effect on plant nutrients, additional elements and pesticide residues in plants, soil and leachate using drainage lysimeters. Australian Journal of Agriculture Research, v.45, p.1619-1638, 1994.

LEMOS, R. C.; SANTOS, R D. Manual de descrição e coleta de solo no campo. Campinas: Sociedade Brasileira de Ciência do Solo, 1996. 84p.

MALAVOLTA, E.; VITTI, G. C.; OLIVEIRA, S. A. Avaliação do estado nutricional das plantas - princípios e aplicações. Piracicaba: Associação Brasileira para Pesquisa da Potassa e do Fosfato, 1997. 319p.

MARSCHNER, H. Mineral nutrition of higher plants Berlin: Academic Press, 1995. 674p.

McLEAN, E.O. Uptake of sodium and other cations by five crop species. Soil Science, v. 82, n. 1, p. 21-28, 1956.

McNEAL, B.L. Effect of rice culture on the reclamation of sodic soils. New York: Longman, 1966. 132p.

MELI, S.; PORTO, M.; BELLIGNO, A.; BUFO, S.A.; MAZZATURA, A.; SCOPA, A. Influence of irrigation with lagooned urban wastewater on chemical and microbiological soil parameters in a citrus orchard under Mediterranean condition. The Science of the Total Environment. v.285, p.69-77, 2002.

MEURER. E. J. Fundamentos de química do solo. Porto Alegre: Gênesis, 2000. 174p. 
ORON, G. Soil as complementary treatment component for simultaneous wastewater disposal and reuse. Water Science \& Technology, v. 34, p.243-252, 1996.

PAGANINI, W. Disposição de Esgotos no solo (escoamento à superfície). São Paulo: Fundo Editorial da AESABESP, 1997. 232p.

PESCOD, M. B. Wastewater treatment and reuse in agriculture. Rome: FAO, 1992. 125. (Irrigação and Drainage Paper, 47).

PIVELI, R.P., DORIA, M.C. Condições operacionais de sistema de tratamento de esgotos por lagoas de estabilização em Lins/SP, (compact disc) In: CONGRESSO BRASILEIRO DE ENGENHARIA SANITÁRIA E AMBIENTAL, 22; Joinville, 2003. Anais Joinville: ABES, 2003.

RAIJ, B. V. Fertilidade do Solo e Adubação. São Paulo: Editora Agronômica CERES, 1991. 343p.

RAIJ, B. V. Análise química de solo para fins de fertilidade. Campinas: Fundação Cargill, 2001. 170p.

RENGASAMY, P.; OLSSON, K.A. Sodicity and soil structure. Australian Journal of Agriculture Research, v.29, p.935-952, 1991.

ROLIM, G. S.; SENTELHAS, P. C. Balanço hídrico normal por Tornthwaite e Mather dados do estado de São paulo. http://www.lce.esalq.usp.br/bhbrasil/Saopaulo/, (14 Jan 2004).

RUSSEL, E.W.; RUSSEL, E.J. Soil conditions and plant growth. London: Longman, 1973. 849p.

SARRUGE, J. R.; HAAG, H. P. Análises químicas em plantas. Piracicaba: ESALQ, 1974. $57 \mathrm{p}$.

SILVA, M.J. Efeito de diferentes métodos de recuperação num solo com problemas de sódio, no projeto de irrigação de São Gonçalo - PB. Viçosa, 1978. 54p. Dissertação (Mestrado) - Universidade Federal de Viçosa.

SUMNER, M.E. Sodic soils: new perspectives. Australian Journal of Soil Research, v.31, p.683-750, 1993.

TAN, K. H. Principles of soil chemistry. Ney York: Marcel Dekker, 1993. cap.7, p.229243: Cation exchange. 
VAZQUEZ-MONTIEL, O.; HORAN, N. J.; MARA, D. D. Management of domestic wastewater for reuse in irrigation. Water Science \& Technology, v. 33, p.355-362, 1996.

YADAV, R.K.; GOYAL, B.; SHARMA, R.K.; DUBEY, S.K.; MINHAS P.S. Post-irrigation impact of domestic sewage effluent on composition of soils, crops and ground water - a case study. Environment International, v.28, p.481-486, 2002. 